Aus der Poliklinik für Präventive Zahnmedizin, Parodontologie und Kariologie des Zentrums für Zahn-, Mund- und Kieferheilkunde im Fachbereich Medizin der Universität Göttingen

\title{
Reparatur partiell insuffizienter Restaurationen - Kompromiss oder vollwertige Therapie?
}

\author{
Habilitationsschrift \\ (kumulatives Verfahren) \\ zur Erlangung der Venia Legendi \\ am Fachbereich Medizin \\ der Georg-August-Universität zu Göttingen
}

Von

Dr. med. dent. Dr. rer. medic.

Philipp Clemens Kanzow, M.Sc. 
Diese kumulative Schrift gründet sich auf die folgenden Originalarbeiten:

Kanzow P, Hoffmann R, Tschammler C, Rödig T, Wiegand A (2017): Attitudes, practice, and experience of German dentists regarding repair restorations. Clin Oral Invest $\underline{21}, 1087-1093$

(Impact-Faktor: 2,386)

Kanzow P, Wiegand A (2020): Retrospective analysis on the repair vs. replacement of composite restorations. Dent Mater 36, 108-118

(Impact-Faktor: 4,495)

Wiegand A, Kanzow P (2020): Effect of repairing endodontic access cavities on survival of single crowns and retainer restorations. J Endod $\underline{46}, 376-382$

(Impact-Faktor: 3,118)

Kanzow P, Wiegand A, Schwendicke F (2016): Cost-effectiveness of repairing versus replacing composite or amalgam restorations. J Dent $\underline{54}, 41-47$

(Impact-Faktor: 3,456)

Kanzow P, Piecha L, Biermann J, Wiegand A (2020): Repair surface conditioning measures affect enamel and dentin bond strength. Oper Dent, Epub ahead of print (Impact-Faktor: 2,213) 


\section{Inhaltsverzeichnis}

1 Einleitung $\quad 1$

1.1 Therapieoptionen für defekte Restaurationen . . . . . . . . . . . . . . . . . . 2

1.2 Indikationen und Durchführung von Reparaturmaßnahmen . . . . . . . . . . 3

1.3 Erfolgsraten von Reparaturmaßnahmen . . . . . . . . . . . . . . . 5

1.4 Fragestellung . . . . . . . . . . . . . . . . 6

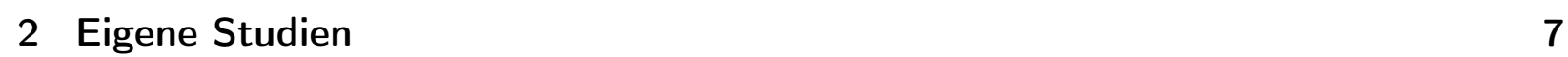

2.1 Umfrage zu Indikationen und Erfahrungen sowie dem praktischen Vorgehen bei der Anfertigung von Reparaturrestaurationen . . . . . . . . . . . . . 7

2.2 Retrospektive Analyse des Überlebens von reparierten bzw. ersetzten Kompositrestaurationen . . . . . . . . . . . . . . . . . 9 9

2.3 Auswirkung einer Reparatur der endodontischen Trepanationsöffnung auf das Überleben indirekter Restaurationen . . . . . . . . . . . . . . . . . . . 11

2.4 Kostenwirksamkeit von Reparaturen und Neuanfertigungen . . . . . . . . . . 13

2.5 Auswirkungen von Reparatur-Vorbehandlungsmaßnahmen auf die Schmelzund Dentinhaftung . . . . . . . . . . . . . . . . . . 15

3 Diskussion $\quad 18$

4 Literaturverzeichnis $\quad 23$

5 Zusammenfassung $\quad 29$

6 Anhang 30

7 Danksagung $\quad 75$ 


\section{Einleitung}

Gemäß der Weltgesundheitsorganisation (WHO) ist Karies die weltweit häufigste Krankheit. Die Behandlungskosten nehmen in den Industrieländern 5-10\% des Gesundheitshaushaltes in Anspruch (World Health Organization 2017). Dabei stellt die Therapie kavitierter kariöser Zahnhartsubstanzdefekte die Hauptindikation für direkte restaurative Behandlungsmaßnahmen dar (Eltahlah et al. 2018). Im Jahr 2018 wurden, gemäß Abrechnungsstatistik der Kassenzahnärztlichen Bundesvereinigung (KZBV), insgesamt 49,7 Millionen direkte zahnärztliche Restaurationen („Füllungen“) bei den Mitglieder*innen der Gesetzlichen Krankenversicherungen ${ }^{1}$ in Deutschland angefertigt (KZBV 2019). Hieraus resultiert eine unmittelbare jährliche Belastung in Höhe von ca. zwei Milliarden Euro für das deutsche Gesundheitssystem. ${ }^{2}$ Unter Berücksichtigung von Begleitleistungen (z.B. Lokalanästhesie, Diagnostik, besondere Maßnahmen beim Füllen) betragen die Kosten etwa fünf Milliarden Euro. Hinzu kommen ggf. privat vereinbarte Mehrkosten für zahnfarbene Kompositrestaurationen im Seitenzahnbereich, die den Patient*innen direkt in Rechnung gestellt werden.

Zahnärztliche Restaurationen aller Art weisen nur eine begrenzte Lebensdauer auf. Häufigste Versagensursachen sind Sekundärkaries (biologische Komplikation) sowie Frakturen der Restauration (funktionelle Komplikation) (Eltahlah et al. 2018). So liegen die mittleren jährlichen Versagensraten (mean annual failure rates, $m A F R s$ ) bei 3,0\% für Amalgamrestaurationen, 2,2\% für Kompositrestaurationen, 1,9\% für Keramikrestaurationen und 1,4\% für Gold-Inlays und -Onlays (Manhart et al. 2004). Der Median der Überlebenszeit für einzelne Restaurationen liegt bei 12,2 Jahren (Goldrestaurationen), 8,5 Jahren (Amalgamrestaurationen) sowie 5,5 Jahren (Kompositrestaurationen) (Manhart et al. 2004). Unter „Praxisbedingungen" scheinen Restaurationen schlechtere Erfolgsraten zu haben: Analysen auf Basis von Abrechnungsdaten zeigen, dass direkte Restaurationen (zwei und mehr Flächen) mit einer jährlichen Interventionsrate von 7,5-9,8\% verbunden sind (Raedel et al. 2017). Zudem zeigen die Auswertungen von Behandlungsdaten, dass der Ersatz versagter Restaurationen gegenüber der Anfertigung von Primärrestaurationen in der zahnärztlichen Praxis überwiegt (Verhältnis 1,3:1) (Eltahlah et al. 2018). Durch das wiederholte Ersetzen von Restaurationen

\footnotetext{
${ }^{1}$ Anmerkung: Dies entspricht etwa 88,1\% der Bevölkerung in Deutschland (GKV-Spitzenverband 2019).

${ }^{2}$ Anmerkung: Basierend auf einer eigenen Kalkulation anhand der im Bewertungsmaßstab für zahnärztliche Leistungen (BEMA) genannten Bewertungszahlen und einem Punktwert von 1,1004 Euro (gültig zum Januar 2019 in Niedersachsen).
} 
kommt es zu einem Fortschreiten in der „Restaurationsspirale“, da nachfolgende Restaurationen zwangsläufig größer werden oder sogar eine indirekte Restauration notwendig machen (Qvist 2015).

\subsection{Therapieoptionen für defekte Restaurationen}

Bei der Therapie partiell insuffizienter Restaurationen stehen entweder das Entfernen und anschließende Ersetzen der gesamten Restauration oder eine Reparatur- / Korrekturmaßnahme der bestehenden Restauration zur Auswahl. Letztere kommen insbesondere dann in Betracht, wenn nicht die gesamte Restauration ersetzt werden muss, z.B. aufgrund einer unterminierenden Sekundärkaries, sondern nur kleinere Teile der Restauration erneuerungsbedürftig sind. Reparatur- oder Korrekturmaßnahmen repräsentieren ein minimalinvasives Therapiekonzept, da sie - im Gegensatz zum vollständigen Entfernen und Ersetzen der gesamten Restauration - eine substanzschonende und defektbezogene Behandlung ermöglichen (Frankenberger et al. 2014). Derart minimalinvasive Therapiekonzepte etablierten sich in den vergangenen Jahren in verschiedenen Bereichen der restaurativen Zahnmedizin (VidnesKopperud et al. 2011; Frankenberger et al. 2014; Doméjean et al. 2015; Oliveira et al. 2016). Während Reparaturmaßnahmen in den letzten Jahrzehnten oftmals als Kompromiss und „Flickerei“ galten, werden sie heute zunehmend häufiger gelehrt. So sind Reparaturmaßnahmen inzwischen weltweit fester Bestandteil der meisten Universitäts-Curricula. Eine systematische Übersichtsarbeit zeigte, dass $83 \%$ der befragten Universitäten angaben, die Anwendung von Reparaturmaßnahmen zu lehren (Kanzow et al. 2017b). Auch die aktuelle Situation in Deutschland folgt diesem Trend: Bei der jüngsten Befragung im Jahr 2018 gaben alle teilnehmenden Universitäten an, Reparaturmaßnahmen durchzuführen. Insgesamt lehrten 90\% der deutschen Universitäten Reparaturmaßnahmen (Kanzow et al. 2018). Dieser Anteil war signifikant größer als in einer früheren nationalen Erhebung aus dem Jahr 2000, bei der der Anteil 50\% betrug (Schriever et al. 2003). 


\subsection{Indikationen und Durchführung von Reparaturmaßnahmen}

Unter dem Begriff der Reparatur- und Korrekturmaßnahmen werden verschiedene Maßnahmen zusammengefasst, die je nach Ausmaß des Defektes indiziert sind: Bei kleinsten Defekten wie Randverfärbungen, suboptimalen Rändern oder Haarrissen kann eine Restauration ggf. weiter beobachtet werden, ohne eine unmittelbare Behandlungsmaßnahme einzuleiten. Rekonturierungsmaßnahmen sind zur Entfernung von Überhängen und zur Umrissoptimierung geeignet. Verfärbungen und Rauigkeiten in der Restaurationsoberfläche lassen sich durch Poliermaßnahmen entfernen und kleine Randspalten mittels Bonding oder fließfähigen Kompositen versiegeln. Sollten diese Verfahren nicht mehr möglich sein, können lokalisierte Defekte einer partiell insuffizienten Restauration durch Antragen von neuem Restaurationsmaterial (Reparaturfüllung) mit oder ohne Präparation der bestehenden Restauration und/oder der angrenzenden Zahnhartsubstanz repariert werden. Dabei ist der Defekt entweder auf die bestehende Restauration begrenzt (z.B. Chipping) oder er erstreckt sich darüber hinaus auch auf die angrenzende Zahnhartsubstanz.

Die Indikationen für den Einsatz von Reparatur- oder Korrekturmaßnahmen sind vielfältig. Mögliche Indikationen sind z.B. der partielle Verlust einer Restauration, Sekundärkaries, ein ausgeprägter Randspalt, Abplatzungen einer Verblendung oder der Verschluss einer Trepanationsöffnung nach endodontischen Behandlungsmaßnahmen eines überkronten Zahnes. Als Hauptvorteil von Reparatur- oder Korrekturmaßnahmen ist zunächst die Schonung der Zahnhartsubstanz sowie der Pulpa zu nennen (Hickel et al. 2013). Die Reparatur / Korrektur einer vorhandenen Restauration ist im Vergleich zur Neuanfertigung mit einem geringeren oder keinem Zahnhartsubstanzverlust verbunden. Ein Fortschreiten in der „Restaurationsspirale" wird verlangsamt und die Gefahr einer Schädigung der Pulpa verringert. Hinzu kommt eine Kosten- und Zeiteinsparung, da bei einer Reparatur- oder Korrekturmaßnahme die intakten Areale der ursprünglichen Restauration beibehalten werden können (Schwendicke 2019). Bei einer Reparaturfüllung sind daher oftmals weniger Zahnflächen als bei einer Neuanfertigung betroffen. Zudem lassen sich Reparaturfüllungen in Form von direkten Füllungen unmittelbar in einer Behandlungssitzung anfertigen. Dies ist bei der Neuanfertigung einer indirekten Restauration, z.B. in Form einer Krone, oftmals nicht möglich. Auch eine Lokalanästhesie wird häufig nicht benötigt. Darüber hinaus verringert die Anwendung von Reparatur- oder Korrekturmaßnahmen die Gefahr einer iatrogenen Schädigung der Nachbarzähne. 
Heute gilt Komposit in den meisten Fällen als Reparaturmaterial der ersten Wahl. Bezüglich des technischen Vorgehens bei der Durchführung von Reparaturmaßnahmen existieren zahlreiche in-vitro Studien, die die Reparatur-Haftwerte auf Komposit (z.B. Tsujimoto et al. 2017; Flury et al. 2019; Kanzow et al. 2019a), Amalgam (z.B. Özcan et al. 2011; Flury et al. 2019; Kanzow et al. 2019a), Keramik (Flury et al. 2019; Shafiei et al. 2019; Veríssimo et al. 2019) sowie Edelmetallen (Chang et al. 2002) untersuchten. Im Hinblick auf klinische Handlungsempfehlungen zur Durchführung von Reparaturen konnte eine systematische Übersichtsarbeit insgesamt 71 verschiedene Reparaturprotokolle für Reparaturen mit Komposit identifizieren (Kanzow et al. 2019b). Dabei zeigte sich, dass folgende Behandlungsschritte durchgängig für die Konditionierung verschiedener Restaurationsmaterialien empfohlen wurden: Anrauung der zu reparierenden Oberfläche, Ätzung mittels Flusssäure (bei silikatkeramischen Oberflächen) sowie Applikation eines Adhäsivs. Es kann davon ausgegangen werden, dass diese Behandlungsschritte bei der klinischen Anwendung von Reparaturmaßnahmen berücksichtigt werden sollten, da sie konsistent über die verschiedenen Protokolle hinweg berichtet und von der Mehrheit der Universitäten im Zusammenhang mit Reparaturmaßnahmen gelehrt werden (Kanzow und Wiegand 2020).

Der Weltverband der Zahnärzt*innen (FDI World Dental Federation) verweist ebenfalls auf die Notwendigkeit einer Anrauung (mittels Sandstrahlung oder Flusssäure-Ätzung bei Silikatkeramiken) und chemischen Konditionierung (Primer mit Silanmethacrylaten und/oder dem funktionellen Monomer 10-MDP [10-Methacryloyloxydecyl-Dihydrogen-Phosphat]).

Eine chemische Konditionierung muss jedoch materialspezifisch erfolgen: So lassen sich Silikatkeramiken sowie silikatisierte Oberflächen mittels Silanmethacrylaten konditionieren. Für Oxidkeramik und Nicht-Edelmetalle werden Phosphorsäuremethacrylate (z.B. 10-MDP) und für Edelmetalle Sulfidmethacrylate benötigt. Für eine Vereinfachung der Konditionierung sind zudem Universalprimer verfügbar, die alle drei der genannten Komponenten enthalten und somit unabhängig vom Restaurationsmaterial verwendet werden können. 


\subsection{Erfolgsraten von Reparaturmaßnahmen}

Bezüglich der Erfolgsraten von Reparaturmaßnahmen an partiell insuffizienten direkten Restaurationen existieren einige prospektive Studien, jedoch ist die Fallzahl oft gering. Im Folgenden werden Studien mit einem Nachbeobachtungszeitraum von mindestens fünf Jahren aufgeführt, die über Reparaturen an bleibenden Zähnen berichteten und sowohl Reparaturen als auch Neuanfertigungen als Behandlungsoptionen berücksichtigten.

Bei Kompositrestaurationen liegen die einzelnen Fallzahlen pro Studie zwischen 14 und 23 Restaurationen und der Nachbeobachtungszeitraum beträgt bis zu zwölf Jahre (Fernández et al. 2015; Martin et al. 2013; Estay et al. 2018). Die mittleren jährlichen Versagensraten über einen Zeitraum von fünf bzw. zehn Jahren für Reparaturen von Kompositrestaurationen wurden mit 0,0-3,0\% angegeben, während ersetzte Restaurationen mittlere jährliche Versagensraten von $0,0-0,9 \%$ zeigten.

Bei Amalgamrestaurationen liegen die Fallzahlen pro Studie zwischen 17 und 27 Restaurationen und der Nachbeobachtungszeitraum beträgt ebenfalls bis zu zwölf Jahre (Gordan et al. 2011; Smales und Hawthorne 2004; Martin et al. 2013; Estay et al. 2018). Die mittleren jährlichen Versagensraten über fünf bzw. sieben Jahre wurden mit 0,0-7,9\% angegeben, während ersetzte Restaurationen mittlere jährliche Versagensraten von 0,0-7,6\% zeigten.

Demgegenüber existiert bisher nur eine Studie bezüglich der Erfolgsraten von Reparaturmaßnahmen an partiell insuffizienten indirekten Restaurationen mit einem mittleren Nachbeobachtungszeitraum von 35 Monaten: Nach drei Jahren zeigten 289 reparierte verblendete Metallrestaurationen (255 Brücken und 34 Einzelkronen) eine kumulative Überlebensrate von 89\% (Özcan und Niedermeier 2002). Zudem präsentierten Hickel et al. (2013) in ihrer systematischen Übersichtsarbeit eigene, bisher unveröffentlichte Originaldaten zur Reparatur von Gold-Teilkronen und -Kronen: Bei 50 Restaurationen, die aufgrund von Randaussprengungen, -spalten oder Sekundärkaries mit einem fließfähigem Komposit repariert wurden, betrug die Überlebensrate nach 5-5,5 Jahren 89,6\%. 


\subsection{Fragestellung}

Reparaturmaßnahmen werden heute zunehmend häufiger gelehrt, ihre Akzeptanz bei Zahnärzt*innen und Patient*innen ist hingegen nicht bekannt. Auch die Frage der Umsetzung, Details zur Indikationsstellung und die genaue Vorgehensweise im täglichen Praxisalltag sind bisher nicht geklärt. Unklar ist auch, ob reparierte Restaurationen unter Umständen häufigere und/oder frühere Reinterventionen benötigen als vollständig ersetzte Restaurationen. Dieser direkte Vergleich wurde bislang nicht in Studien mit großer Fallzahl untersucht, obgleich er für die Entscheidungsfindung beim Vorliegen defekter Restaurationen in der täglichen Praxis von zentraler Bedeutung ist.

Bisherige Studien zeigten, dass Reparaturmaßnahmen in der Lage sind, die initialen Behandlungsrisiken und -kosten zu senken. Wie sich die Notwendigkeit nachfolgender Interventionen gestaltet und ob sie langfristig möglicherweise mit höheren Folgekosten als beim vollständigen Ersatz einer Restauration einhergehen, ist jedoch nicht bekannt.

Oftmals liegt bei einer partiell insuffizienten Restauration zudem eine Mitbeteiligung von Zahnhartsubstanz (Schmelz und/oder Dentin) vor. Die bei der Reparatur verwendeten Konditionierungsmaßnahmen verbessern einerseits die Haftung zwischen Restaurationsmaterial und Reparaturkomposit, könnten andererseits jedoch die Haftung des Komposits an der Zahnhartsubstanz negativ beeinflussen.

Im Einzelnen soll die vorliegende Studienserie daher Antworten auf die folgenden Fragen geben:

1. Wie sind Reparaturmaßnahmen im täglichen Praxisalltag integriert?

2. Ist die Lebensdauer reparierter Restaurationen vom Zeitpunkt der Reparatur an vergleichbar mit der Lebensdauer von neuen, d.h. vollständig ersetzten Restaurationen?

3. Wie wirken sich Reparaturen im Sinne eines Trepanationsverschlusses auf die Lebensdauer indirekter Restaurationen aus?

4. Wie wirken sich Reparaturen auf die Lebensdauer der betroffenen Zähne aus und wie gestaltet sich die Kostenwirksamkeit im Vergleich zu Ersatzrestaurationen aus gesundheitsökonomischer Sicht?

5. Inwieweit haben gängige Reparatur-Konditionierungsmaßnahmen negative Auswirkungen auf die Schmelz- und Dentinhaftung? 


\section{Eigene Studien}

Um die aufgestellten Fragen zu beantworten, erhob die vorliegende Studienserie Aussagen zur Indikation und praktischen Vorgehensweise bei der Anwendung von Reparaturmaßnahmen aus der Sicht von Zahnärzt*innen und ermittelte die Akzeptanz von Reparaturen bei Zahnärzt*innen und - indirekt - bei ihren Patient*innen. Zudem wurden klinische Erfolgsraten reparierter direkter und indirekter Restaurationen ermittelt und die Kostenwirksamkeit von Reparaturen und Neuanfertigungen miteinander verglichen. Ferner wurde der Einfluss verschiedener Reparatur-Konditionierungsverfahren auf die Haftwerte an Zahnhartsubstanz systematisch untersucht.

\subsection{Umfrage zu Indikationen und Erfahrungen sowie dem praktisch- en Vorgehen bei der Anfertigung von Reparaturrestaurationen}

Im Rahmen der Studie wurde eine repräsentative Befragung von Zahnärzt*innen in Deutschland zur Indikation und Vorgehensweise bei der Anfertigung von Reparaturmaßnahmen sowie zu ihren Erfahrungen und den Erfahrungen ihrer Patient*innen mit Reparaturmaßnahmen durchgeführt.

Für die Umfragestudie wurde ein standardisierter und vorab pilotierter Fragebogen mit neun Fragegruppen (1. demographische Daten, 2. Häufigkeiten von Reparaturen verschiedener Materialien, 3. Gründe für Reparaturen, 4. Entscheidungskriterien für die Beurteilung der Reparierbarkeit, 5. Indikationen für die Anfertigung von Reparaturen, 6. genutzte Materialien, 7. Techniken und klinisches Vorgehen, 8. Patient*innenakzeptanz sowie 9. Einschätzung zur Langlebigkeit) an alle aktiven und bei der Zahnärztekammer Niedersachsen ${ }^{1}$ registrierten Zahnärzt*innen $(\mathrm{n}=6.600)$ versandt. Die Studie wurde vorab von der Ethik-Kommission der Universitätsmedizin Göttingen unter der Antragsnummer 18/11/14 genehmigt.

Die statistische Auswertung der rückgesandten Fragebögen ( $\mathrm{n}=1.805$, Rücklaufquote: 28\%) erfolgte zunächst deskriptiv. Darüber hinaus kamen verschiedene statistische Tests zur Anwendung: Die Häufigkeit, mit der verschiedene Restaurationsarten repariert werden, wur-

\footnotetext{
${ }^{1}$ Anmerkung: Feststehende Begriffe, Eigennamen etc. bleiben in der vorliegenden Arbeit in ihrer Originalfassung erhalten. Das bedeutet, dass keine Anpassung im Sinne einer gendergerechten Sprache vorgenommen wird. Dies bringt jedoch keine Geschlechterdiskriminierung oder eine Verletzung des Gleichheitsgrundsatzes zum Ausdruck.
} 
de mittels Wilcoxon-Rangsummen-Tests (korrigiert nach Bonferroni-Holm) verglichen. Der Einfluss von kategorialen zahnarzt- und praxisspezifischen Faktoren (Geschlecht, Spezialisierung sowie Praxisart und -ort) wurde mit Kruskal-Wallis-Tests ermittelt. Der Einfluss des Lebensalters wurde mit dem Rangkorrelationskoeffizienten Kendall's Tau beschrieben. Abschließend wurden geordnete logistische Regressionsanalysen genutzt, um den Einfluss unterschiedlicher Reparaturhäufigkeiten und -techniken auf die Einschätzung von Reparaturmaßnahmen zu ermitteln.

Grundsätzlich werden Reparaturrestaurationen von den befragten Zahnärzt*innen häufig angefertigt, da insgesamt nur 2,2\% der Zahnärzt*innen angaben, Reparaturmaßnahmen nie durchzuführen. Trotz signifikanter demographischer Einflussfaktoren für einzelne Restaurationsarten konnte kein klarer „Zahnarzttyp“ für oder gegen Reparaturen identifiziert werden. Hauptindikationen für Reparaturen waren der partielle Verlust einer Restauration, angrenzende Zahnhartsubstanzverluste sowie Trepanationsöffnungen in indirekten Restaurationen nach endodontischen Behandlungen. Auffällig war die große Zurückhaltung bei der Versorgung von Sekundärkaries. Als Gründe für die Anwendung von Reparaturmaßnahmen wurden vor allem die Verlängerung der Lebensdauer sowie Zahnhartsubstanzschonung angeführt. Kostengründe, Patient*innenwunsch und Zeitreduktion wurden ebenfalls genannt. Das Erreichen der Gewährleistungszeit spielte mit 6,2\% eine untergeordnete Rolle. Als Entscheidungskriterium für die Anfertigung einer Reparatur wurde von $91 \%$ der befragten Zahnärzt*innen die Größe des Defektes genannt. Auch zahn- und restaurationsbezogene Faktoren, z.B. die Art des Materials, die Größe der ursprünglichen Restauration, die Lokalisation des Defektes, die Art des betroffenen Zahnes und die Frage, wer die ursprüngliche Restauration angefertigt hatte, wurden genannt. Zur Reparatur wurde, unabhängig vom Restaurationsmaterial der Primärrestauration, zumeist Komposit verwendet.

Die Patient*innenakzeptanz wurde indirekt über die befragten Zahnärzt*innen erhoben und von diesen als sehr hoch eingeschätzt: Nur 7,1\% berichteten, dass ihre Patient*innen Reparaturmaßnahmen ablehnen. Darüber hinaus gaben $62 \%$ der Befragten an, dass ihre Patient*innen Reparaturen wünschen, auch wenn hier mit einer kürzeren Haltbarkeit im Vergleich zu Ersatzrestaurationen zu rechnen sei. Auch bei den befragten Zahnärzt*innen war die Akzeptanz dentaler Reparaturen hoch: Von 75\% wurden Reparaturen als permanente Restaurationen betrachtet, jedoch mit niedrigeren Erfolgsraten als neu angefertigte Restaurationen. Ferner sahen 15\% die Erfolgsrate von Reparaturen als mit denen von neu angefer- 
tigten Restaurationen vergleichbar an. Je häufiger Reparaturen durchgeführt wurden, desto signifikant besser wurde ihre Langlebigkeit bei allen initialen Restaurationsmaterialien eingeschätzt $(\mathrm{p}<0,001$; Quotenverhältnis [odds ratio, OR]: 1,44-1,96). Bei der Durchführung von Reparaturen zeigten sich große Unterschiede im Hinblick auf die Konditionierung der Restaurationsoberfläche. Hier wurden vor allem die Reinigung der Restaurationsoberfläche, das Anlegen von Makroretentionen, Anrauen mit Diamanten, Anätzen mit Phosphorsäure, Anätzen mit Flusssäure (nur bei Keramiken), Sandstrahlen sowie das Applizieren von Silan-Lösungen und Adhäsivsystemen genannt. Es zeigte sich, dass die Anwendung von Phosphorsäure bei Kompositrestaurationen ( $\mathrm{p}=0,007$; Quotenverhältnis: 1,42) und die Konditionierung mittels Sandstrahlung ( $\mathrm{p} \leq 0,012$; Quotenverhältnis: 1,44-3,09) bei allen Restaurationsmaterialien zu einer signifikant höheren Erfolgseinschätzung dentaler Reparaturen führte.

\subsection{Retrospektive Analyse des Überlebens von reparierten bzw. er- setzten Kompositrestaurationen}

Ziel der Studie war es, die Lebensdauer von Reparatur- und Ersatzrestaurationen ab dem Zeitpunkt der Reparatur bzw. der Erneuerung von mehrflächigen Kompositrestaurationen im Front- und Seitenzahnbereich zu ermitteln und miteinander zu vergleichen. Darüber hinaus wurde der Effekt von Reparaturmaßnahmen auf die Lebensdauer initialer Restaurationen untersucht. Ebenfalls galt es, potentielle patient*innen-, zahn- und restaurationsbezogene Risikofaktoren mit Einfluss auf die Lebensdauer von initialen Restaurationen sowie Reparaturund Ersatzrestaurationen zu identifizieren.

Vor Beginn wurde die Studie unter der Antragsnummer 7/9/18 von der Ethik-Kommission der Universitätsmedizin Göttingen genehmigt. In die retrospektive Studie wurden alle Kompositrestaurationen mit mindestens zwei Flächen, die zwischen den Jahren 2000 und 2015 in der Poliklinik für Präventive Zahnmedizin, Parodontologie und Kariologie der Universitätsmedizin Göttingen in bleibenden Zähnen angefertigt wurden, eingeschlossen und nachverfolgt. Daten zu Folgeinterventionen wurden den digitalen Patient*innenakten und der Abrechnungsdokumentation entnommen. Nachfolgende Füllungstherapien, bei denen mindestens eine Fläche der initialen Restauration erhalten blieb, wurden als Reparaturrestauration gewertet. Sofern alle Flächen der initialen Restauration ersetzt wurden, wurde die neue Füllung als Ersatzrestauration eingestuft. Reparierte und ersetzte Restaurationen wur- 
den ebenfalls nachbeobachtet und das Ergebnis separat für initiale, reparierte und ersetzte Restaurationen für drei verschiedene Zielparameter analysiert: a) „Success“ (Reparatur = Versagen), b) „Survival 1“ (erste Reparatur = Überleben, weitere Reparatur = Versagen) und c) ,Survival 2“ (multiple Reparaturen = Überleben, alle Flächen repariert = Versagen). Unabhängig von der Anwendung von Reparaturmaßnahmen wurde bei allen Zielparametern die Anfertigung einer indirekten Restauration, eine Wurzelkanalbehandlung sowie die Extraktion des Zahnes als Versagen gewertet.

Das Überleben der Restaurationen wurde mittels Kaplan-Meier-Statistik nachverfolgt und die kumulativen Überlebensraten ermittelt. Für verschiedene Zeiträume (bis zu 15 Jahre) wurden mittlere jährliche Versagensraten anhand folgender Formel berechnet (Opdam et al. 2010):

$$
(1-y)^{z}=1-x \quad y=1-\sqrt[z]{1-x}
$$

$y=$ mittlere jährliche Versagensrate; $x=$ Anteil versagter Restaurationen; $z=$ Nachbeobachtungszeitraum

Mittels Log-Rank-Tests wurden jeweils separat für initiale, reparierte und ersetzte Restaurationen die verschiedenen Zielparameter miteinander verglichen und für multiples Testen gemäß Bonferroni-Holm korrigiert. Separat für initiale, reparierte und ersetzte Restaurationen sowie „Success“, ,Survival 1“ und ,Survival 2" wurden potentielle patient*innen-, zahnund restaurationsbezogene Risikofaktoren identifiziert und ihre Hazard-Verhältnisse (hazard ratios, HRs) berechnet. Eine Abhängigkeit mehrerer Restaurationen bei identischen Patient*innen wurde berücksichtigt.

Es konnten 8.542 initiale Kompositrestaurationen bei 3.239 Patient*innen eingeschlossen und bis zu 19 Jahre lang nachverfolgt werden. In diesem Zeitraum wurden von den initial angefertigten Restaurationen 616 Restaurationen repariert und 264 ersetzt. Die Erfolgsraten (Zielparameter ,Success“) von Reparatur- und Ersatzrestaurationen betrugen nach zehn Jahren 43,4 bzw. 48,6\%; der Unterschied war statistisch nicht signifikant ( $\mathrm{p}=0,866$, Abbildung $2.1)$. 


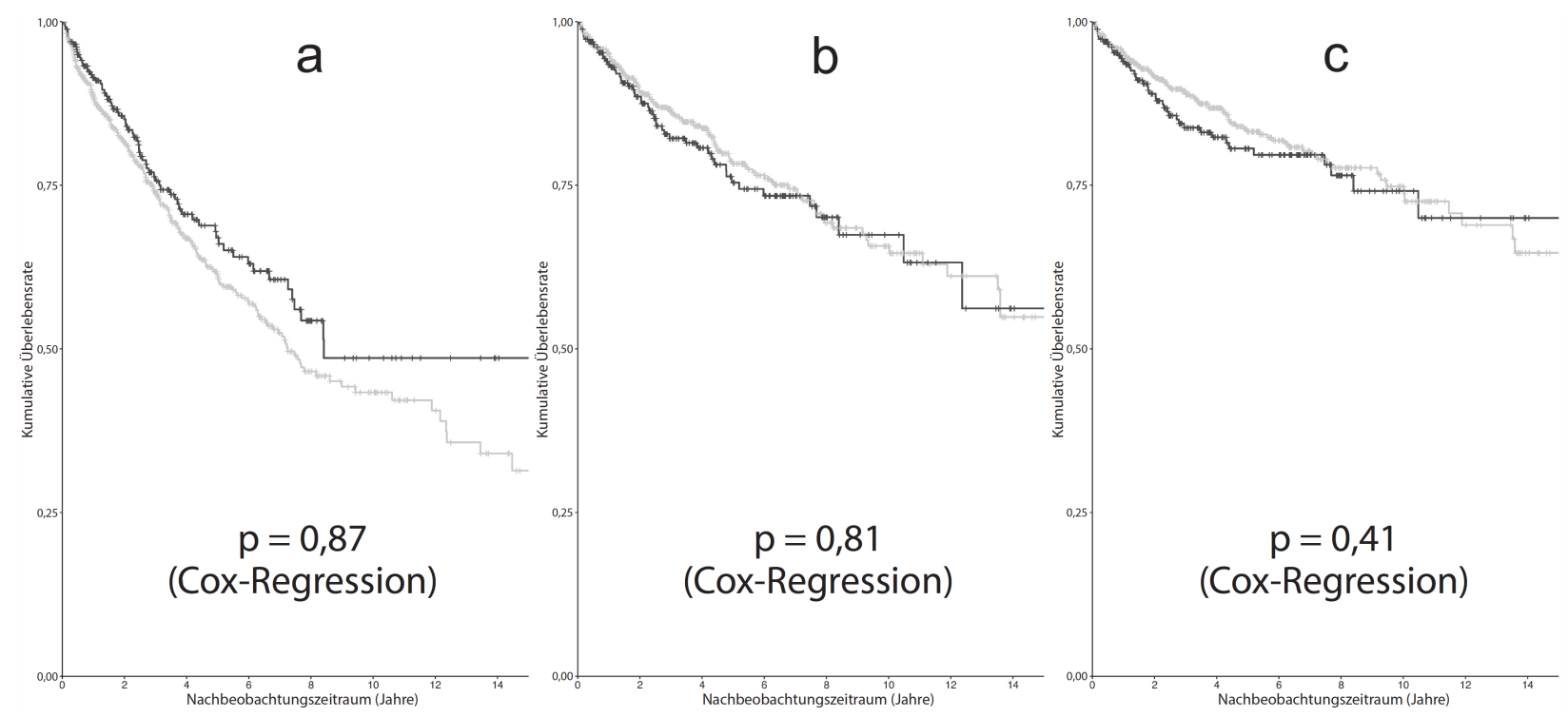

Abbildung 2.1: Kaplan-Meier-Überlebenskurven für reparierte (graue Kurve) und ersetzte (schwarze Kurve) Restaurationen und den drei Zielparametern a) „Success“, b) „Survival 1“ und c) „Survival 2“ (reprinted from Dental Materials, volume 36, Kanzow P, Wiegand A, Retrospective analysis on the repair vs. replacement of composite restorations, pages 108-118, 2020, with permission from Elsevier. https://dx.doi.org/10.1016/j.dental.2019.11.001.).

Insgesamt konnte die Überlebensrate direkter Kompositrestaurationen nach zehn Jahren durch Reparaturmaßnahmen signifikant von 68,3\% („Success“, mittlere jährliche Versagensrate: $3,7 \%$ ) auf 77,3\% („Survival 1“, mittlere jährliche Versagensrate: $2,5 \%$ ) verbessert werden $(\mathrm{p}<0,001)$. Dabei verlängerten wiederholte Reparaturen die Lebensdauer mehr als einmalige Reparaturen (Zielparameter „Survival 1“ vs. „Survival 2“, $\mathrm{p}=0,010$ ). Die Lebensdauer von initialen, reparierten und ersetzten Restaurationen war jeweils von verschiedenen patient*innen-, zahn- und restaurationsbezogenen Risikofaktoren abhängig (z.B. das Vorhandensein eines herausnehmbaren Zahnersatzes oder eine vorherige Wurzelkanalbehandlung des betroffenen Zahnes).

\subsection{Auswirkung einer Reparatur der endodontischen Trepanations- öffnung auf das Überleben indirekter Restaurationen}

Ziel der Studie war es, die Lebensdauer von indirekten Restaurationen (Einzelkronen, Brückenanker und Teleskopkronen) nach Reparatur (Verschluss der Trepanationsöffnung) zu ermitteln sowie potentielle patient*innen-, zahn- und restaurationsbezogene Risikofaktoren zu identifizieren.

Die Studiendurchführung wurde vorab von der Ethik-Kommission der Universitätsmedizin Göttingen unter der Antragsnummer 17/10/18 genehmigt. In die retrospektive Stu- 
die wurden indirekte Einzelzahnrestaurationen (Einzelkronen) bzw. Ankerrestaurationen (Brückenanker und Teleskopkronen), die zwischen den Jahren 2000 und 2015 eine Wurzelkanalbehandlung (Primärbehandlung oder orthograde Revisionsbehandlung) mit Verschluss der Trepanationsöffnung mittels Komposit in der Poliklinik für Präventive Zahnmedizin, Parodontologie und Kariologie der Universitätsmedizin Göttingen erhielten, eingeschlossen und nachverfolgt. Daten zu Folgeinterventionen wurden anhand von Abrechnungspositionen und Einträgen aus den digitalen und papierbasierten Patient*innenakten entnommen. Die Entfernung, Erneuerung, Rezementierung sowie der Verlust der indirekten Restauration oder das Erneuern des Trepanationsverschlusses wurde als „Versagen“ gewertet. Im Falle von Revisionsbehandlungen oder der Extraktion des Zahnes wurde die zugehörige Restauration zensiert.

Das Überleben der Restaurationen wurde mittels Kaplan-Meier-Statistik nachverfolgt und die kumulativen Überlebensraten ermittelt. Für verschiedene Zeiträume (bis zu zehn Jahre) wurden mittlere jährliche Versagensraten anhand der zuvor bereits genannten Formel berechnet. Zunächst erfolgte eine einfaktorielle Signifikanzprüfung potentieller patient*innen-, zahn- und restaurationsbezogener Risikofaktoren mittels uni-variater Log-Rank-Tests. Nachfolgend wurden signifikante Risikofaktoren in ein multifaktorielles Cox-Regressions-Modell übernommen und ihre Hazard-Verhältnisse berechnet. Eine Abhängigkeit mehrerer Restaurationen bei identischen Patient*innen wurde berücksichtigt.

Es konnten 180 indirekte Restaurationen bei 151 Patient*innen eingeschlossen und bis zu 14 Jahre lang nachverfolgt werden. Nach zehn Jahren betrug die Überlebensrate der reparierten indirekten Restaurationen 48,8\% und die zugehörige mittlere jährliche Versagensrate 6,9\%. Der Median der Überlebenszeit lag bei 9,7 Jahren (95\%-Konfidenzintervall: 7,3-12,0 Jahre). Bei 84 indirekten Restaurationen war das Zementierungsdatum und somit das Alter zum Zeitpunkt der Reparatur bekannt (im Mittel: 4,5土4,0 Jahre). Hier konnte die Lebensdauer der indirekten Restaurationen deutlich verlängert werden (Median der Überlebenszeit nach Reparatur: 12,7 Jahre). In der multi-variaten Cox-Regressionsanalyse zeigte sich die Art der Restauration (Einzelzahnrestauration vs. Ankerrestauration) als einziger signifikanter Einflussfaktor ( $\mathrm{p}=0,023$; Hazard-Verhältnis im Vergleich zu Einzelzahnrestaurationen: 2,54, 95\%-Konfidenzintervall: 1,14-5,67). Dabei wies die Reparatur von Einzelzahnrestaurationen eine bessere Prognose als die von Ankerrestaurationen auf (Abbildung 2.2). 


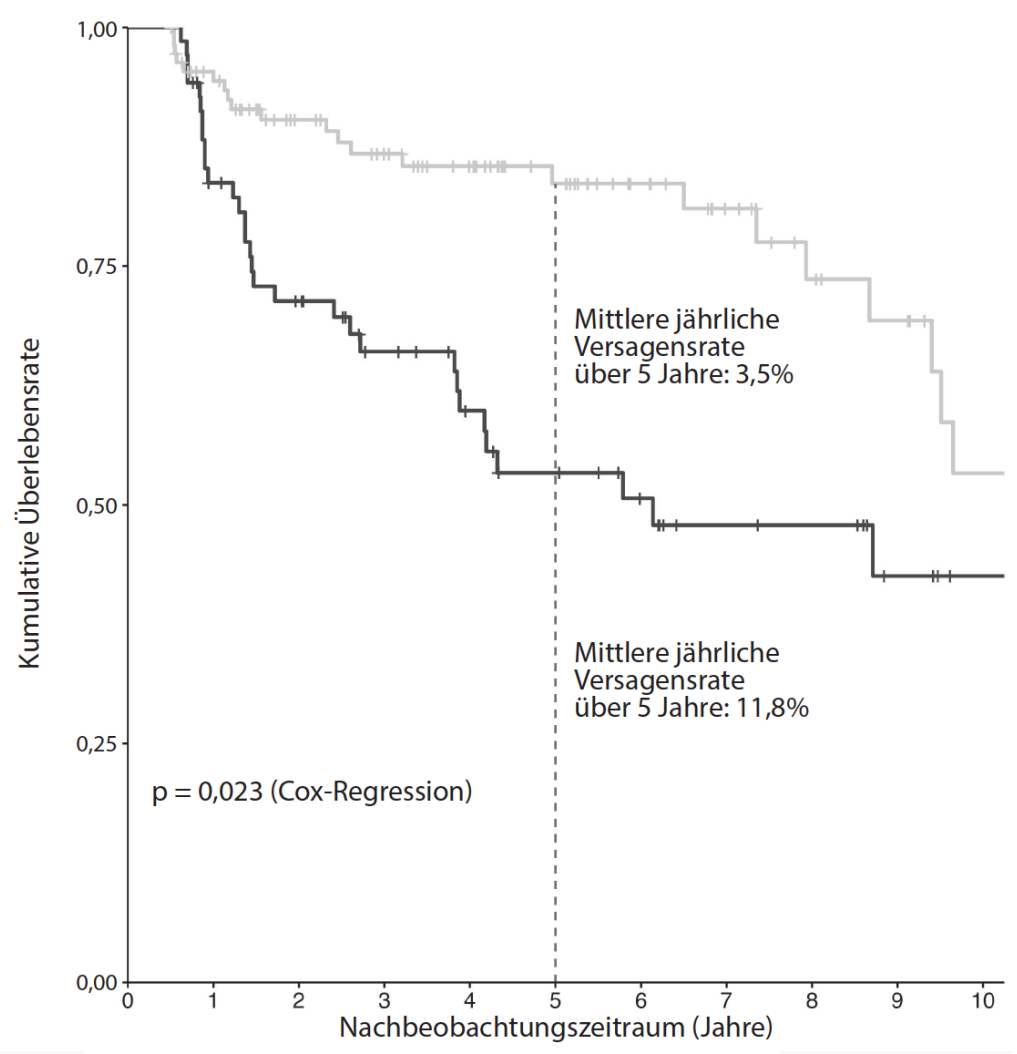

Abbildung 2.2: Kaplan-Meier-Überlebenskurven für Trepanationsverschlüsse in Einzelzahnrestaurationen (graue Kurve) vs. Ankerrestaurationen (schwarze Kurve) (Journal of Endodontics, volume 46, Wiegand A, Kanzow P, Effect of repairing endodontic access cavities on survival of single crowns and retainer restorations, pages 376-382, 2020, with permission from Elsevier. https://dx.doi.org/10.1016/j.joen.2019.11.012.).

\subsection{Kostenwirksamkeit von Reparaturen und Neuanfertigungen}

Im Rahmen der Studie wurde die Kostenwirksamkeit von Reparaturmaßnahmen bzw. Neuanfertigungen bei partiell insuffizienten Komposit- und Amalgamrestaurationen in verschiedenen Szenarien miteinander verglichen.

Hierfür wurde der Effekt von Reparaturmaßnahmen auf 1.000 partiell insuffiziente Kompositbzw. Amalgamrestaurationen in bleibenden vitalen Molaren simuliert. Mittlere jährliche Versagensraten von Reparatur- und Ersatzrestaurationen bei Komposit- und Amalgamrestaurationen wurden der Literatur entnommen. Die für Folgeinterventionen zu erwartenden durchschnittlichen Behandlungskosten wurden anhand des Bewertungsmaßstabs für zahnärztliche Leistungen (BEMA) und der Gebührenordnung für Zahnärzte (GOZ) kalkuliert. Als Wirksamkeitsmaß wurde die Dauer des Zahnerhalts verwendet, den es zu maximieren galt.

Ausgangspunkt der Simulationen waren im Basis-Szenario dreiflächige, partiell insuffiziente Restaurationen. Es wurde angenommen, dass Reparaturrestaurationen ausschließlich mit Komposit und Ersatzrestaurationen mit dem jeweiligen Ursprungsmaterial (Komposit oder 
Amalgam) durchgeführt werden. Für das Basis-Szenario wurde ebenfalls davon ausgegangen, dass Reparaturmaßnahmen - gemessen an der Anzahl der Füllungsflächen - zu keiner Vergrößerung der Füllung führen, während die Anzahl der Füllungsflächen bei Neuanfertigungen um +1 ansteigt. Des Weiteren wurde festgelegt, dass eine Füllung nur einmalig repariert werden kann, bevor eine Neuanfertigung notwendig wird (die dann im weiteren Verlauf wieder repariert werden kann). Das vereinfachte Modell ist in der Abbildung 2.3 dargestellt.

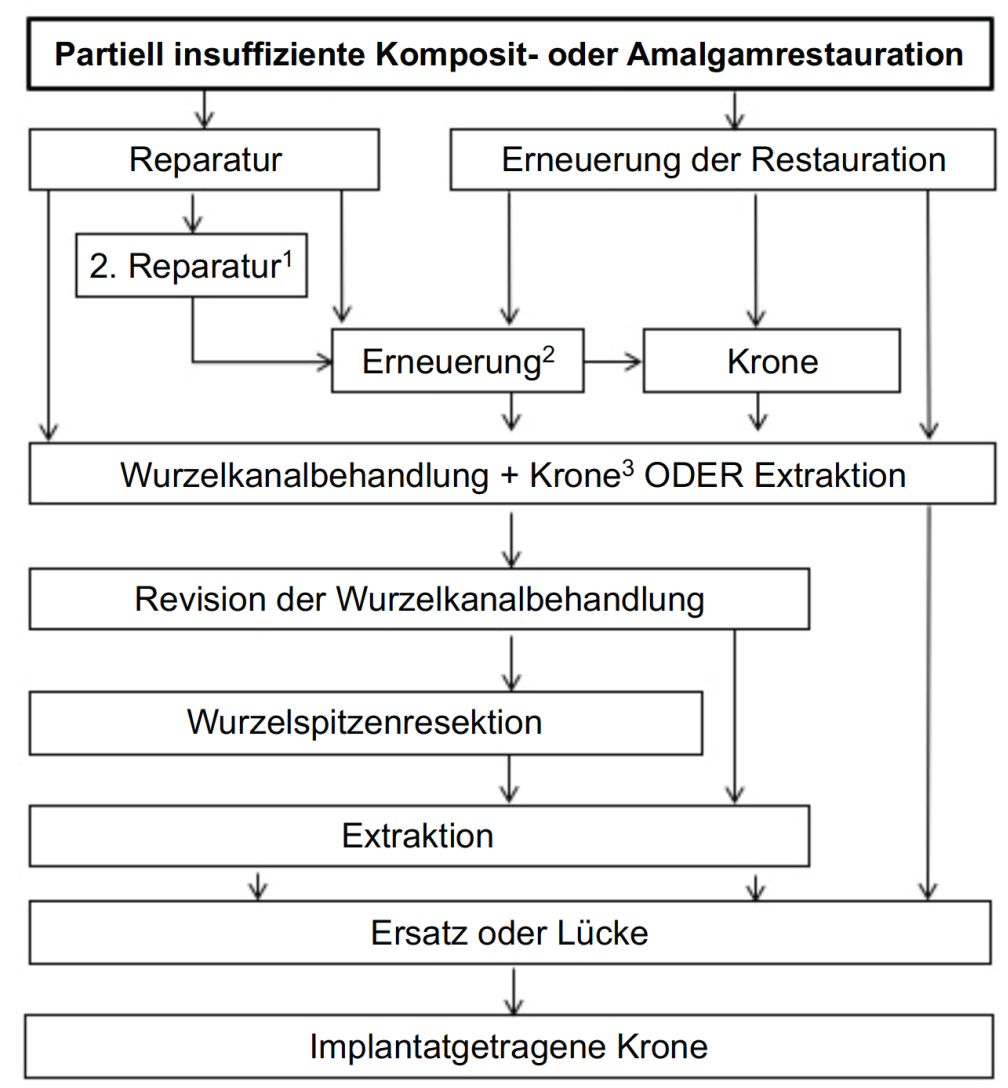

Abbildung 2.3: Das der Simulation zugrundeliegende Modell mit möglichen „Pfaden“ ( ${ }^{1}$ wiederholte Reparaturen waren nur im Rahmen der Sensitivitätsanalyse möglich, ${ }^{2}$ die Anzahl der wiederholten Neuanfertigungen wurde im Rahmen der Sensitivitätsanalysen variiert, ${ }^{3}$ Zähne wurden nach der Wurzelkanalbehandlung überkront, sofern noch keine Krone vorhanden war) (reprinted from Journal of Dentistry, volume 54, Kanzow P, Wiegand A, Schwendicke F, Cost-effectiveness of repairing versus replacing composite or amalgam restorations, pages 41-47, 2016, with permission from Elsevier. https://dx.doi.org/10.1016/j.jdent.2016.08.008.).

Um die Zuverlässigkeit der Ergebnisse zu prüfen, wurden mehrere Szenarien (z.B. initial bereits vierflächige Füllung, Reparatur lässt sich auch ohne Neuanfertigung mehrfach wiederholen, Ersatzrestaurationen führen nicht zwangsläufig zu einer Zunahme der Füllungsflächen) simuliert und Sensitivitätsanalysen durchgeführt.

Die Untersuchung erfolgte unter Einsatz eines Markov-Modells mit Monte-Carlo-Mikrosimulationen. Über die gesamte Lebenszeit wurden die Kosten und die Wirksamkeit (Dauer des Zahnerhalts in Jahren) im weiteren Verlauf verfolgt. 
Reparaturen von Kompositrestaurationen waren im Basis-Szenario geringfügig teurer als Neuanfertigungen (326 vs. 321 Euro), jedoch auch wirksamer (24,7 vs. 24,0 Jahre Zahnerhalt). Bei Amalgamrestaurationen waren Reparaturen im Basis-Szenario zwar deutlich teurer (467 vs. 326 Euro), aber ebenfalls wirksamer (24,3 vs. 23,7 Jahre). Je höher die zusätzlichen Kosten durch Reparaturmaßnahmen für das Gesundheitssystem sein durften (höhere Zahlungsbereitschaftsschwelle), desto eher waren Reparaturen im Basis-Szenario kostenwirksam. Für ein zusätzlich gewonnenes Jahr des Zahnerhalts mussten 7,14 Euro bei Komposit- und 235,- Euro bei Amalgamrestaurationen ausgegeben werden. Diese beiden Angaben stellen die inkrementelle Kosten-Effektivitäts-Relation (IKER) dar, d.h. die zusätzlichen Kosten pro gewonnener Einheit des Effektivitätsmaßes (Zahnerhalt gemessen in Jahren). Wenn Reparaturen weniger als 67,- Euro oder Neuanfertigungen über 166,- Euro kosteten, wären Reparaturen von Kompositrestaurationen immer kostenwirksam. Bei Amalgamrestaurationen wäre dies auch bei Kosten unter 44,- Euro für Reparaturen und über 163,- Euro für Neuanfertigungen nicht der Fall. Weitere Szenarien zeigten, dass Reparaturen von Kompositfüllungen bei initial vierflächigen Füllungen (IKER: -23,6), im Falle der Möglichkeit wiederholter Reparaturen (IKER: -1,3) sowie bei der Behandlung von Sekundärkaries als Versagensursache (IKER: -87,3) nicht nur wirksamer, sondern auch immer kostenwirksam waren. Für Amalgamrestaurationen war dies in keinem Szenario der Fall. Reparaturen gingen dabei immer mit höheren Kosten einher.

\subsection{Auswirkungen von Reparatur-Vorbehandlungsmaßnahmen auf die Schmelz- und Dentinhaftung}

Ziel der Studie war es, den Einfluss verschiedener Reparatur-Konditionierungsmaßnahmen (Sandstrahlung, Silikatisierung, Flusssäure-Ätzung, Applikation eines Universalprimers bzw. selbstätzenden Keramikprimers) auf die Reparatur-Haftwerte an Schmelz- und Dentinoberflächen zu untersuchen. Das verwendete Universaladhäsiv kam entweder im Self-Etch-Verfahren oder im Etch\&Rinse-Verfahren zum Einsatz, wobei bei letzterem ebenfalls der potentielle Einfluss der Applikations-Reihenfolge untersucht wurde.

Unterschiedliche Arten einer Kontamination durch verschiedene Reparatur-Oberflächenbearbeitungen wurden auf bovinen Schmelz- und Dentin-Prüfkörpern simuliert. Je Untergruppe wurden $n=16$ Prüfkörper angefertigt (siehe Tabelle 2.1). 


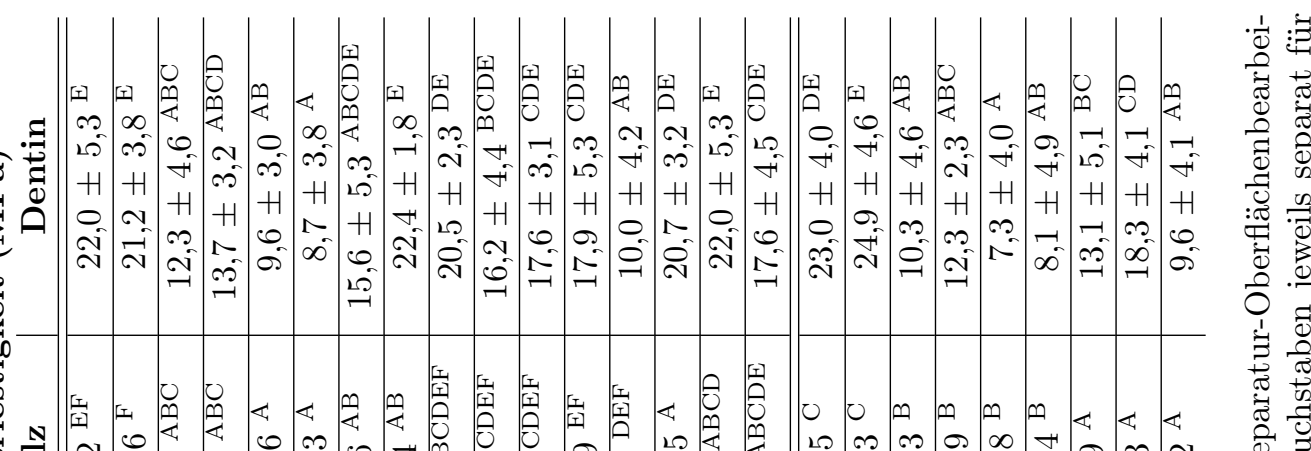

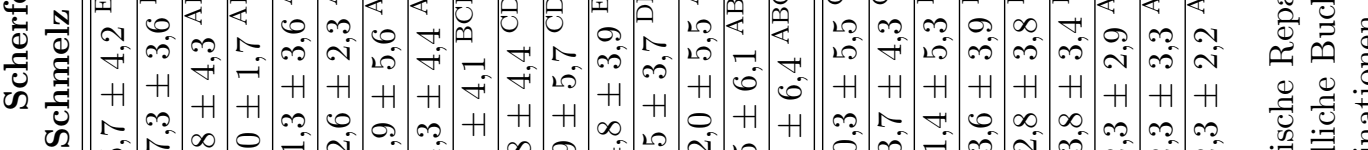

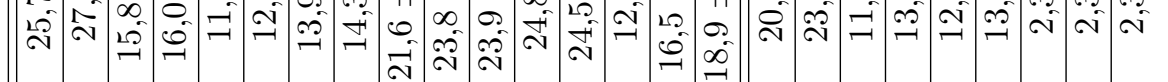

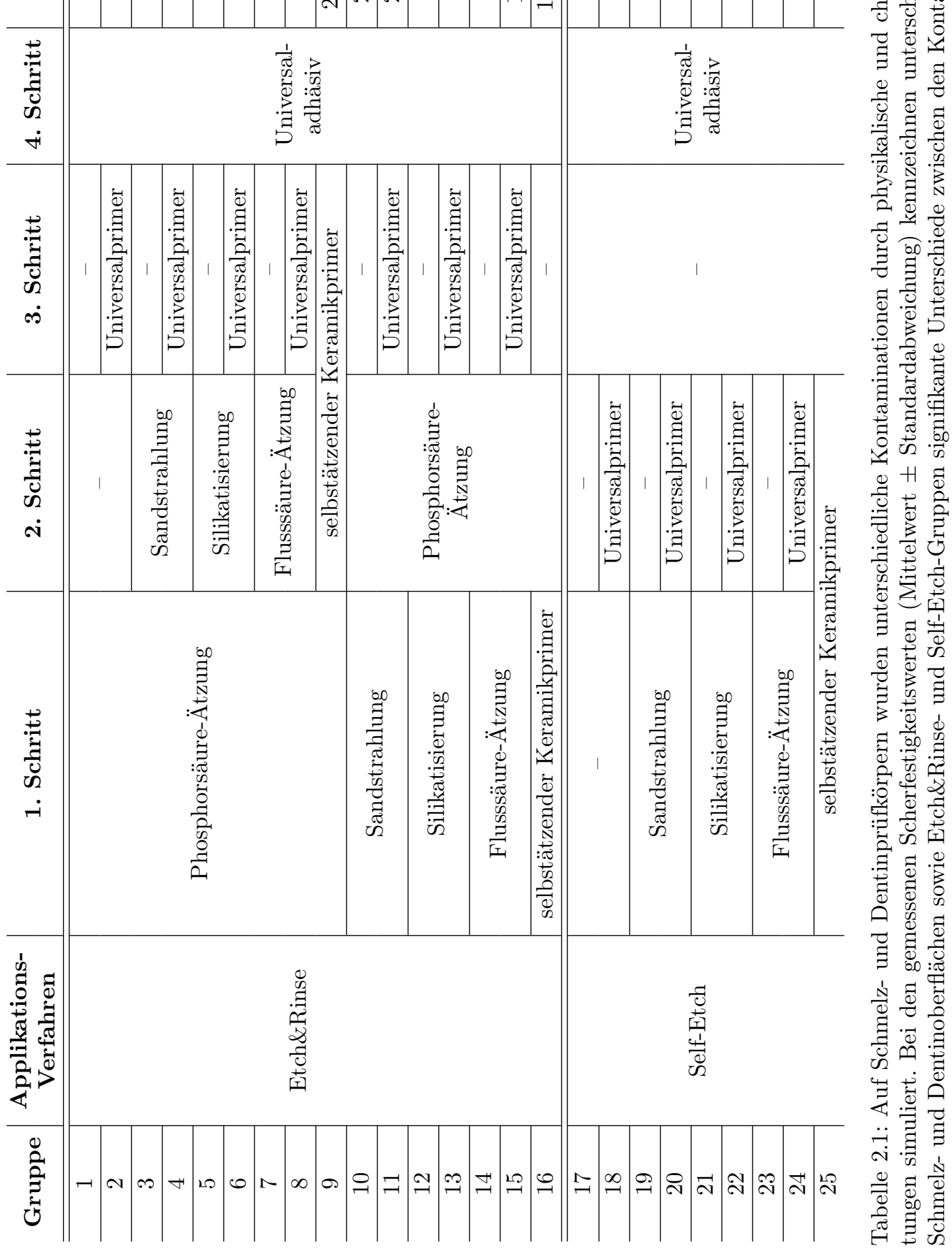


Abschließend kam bei allen Gruppen ein Universaladhäsiv, entweder im Self-Etch- oder im Etch\&Rinse-Verfahren, zur Anwendung. Bei den Etch\&Rinse-Gruppen erfolgte die Kontamination entweder vor oder nach Applikation der Phosphorsäure.

Nach Applikation des Reparaturkomposits wurden alle Prüfkörper im Thermolastwechselverfahren (10.000 Zyklen, 5-55 C) künstlich gealtert. Die Scherfestigkeiten wurden mit einer Universalprüfmaschine bestimmt und die Versagensmuster stereomikroskopisch untersucht. Zusätzlich wurden von den kontaminierten Oberflächen rasterelektronenmikroskopische Aufnahmen angefertigt. Die statische Auswertung der gemessenen Scherfestigkeitswerte erfolgte mittels einfaktorieller sowie mehrfaktorieller Varianzanalysen (ANOVAs) und Post-HocTests. Die Auswertung der beobachteten Versagensmuster erfolgte durch Chi²-Tests mit Bonferroni-Korrektur. Zusätzlich wurden die Weibull-Verteilungsparameter berechnet.

Die gemessenen Scherfestigkeitswerte sind in der Tabelle 2.1 dargestellt. Im Etch\&RinseVerfahren wurden die Scherfestigkeitswerte (Kontrolle: Schmelz 25,7 $\pm 4,2 \mathrm{MPa}$, Dentin 22,0 $\pm 5,3 \mathrm{MPa}$ ) sowohl von den simulierten Reparatur-Konditionierungsverfahren $(\mathrm{p}<0,001)$ als auch von der Applikationsreihenfolge der Phosphorsäure (vor oder nach der ReparaturKonditionierung, $\mathrm{p}<0,001)$ beeinflusst. Auf den Schmelzoberflächen wurden die Haftwerte bei allen Gruppen, außer bei Sandstrahlung bzw. Silikatisierung und nachfolgender Applikation von Phosphorsäure, herabgesetzt. Sowohl der selbstätzende Keramikprimer als auch der Universalprimer führten nicht zu reduzierten Haftwerten. Auf den Dentinoberflächen verursachte lediglich eine Phosphorsäure-Ätzung mit nachfolgender Sandstrahlung (sowohl Aluminiumoxid als auch silikatisiertes Aluminiumoxid) bzw. eine Silikatisierung mit nachfolgender Applikation von Phosphorsäure und dem Universalprimer signifikant reduzierte Haftwerte. Es zeigten sich fast ausschließlich adhäsive und gemischte Versagensmuster. Kohäsive Versagensmuster traten nur bei den Schmelzprüfkörpern auf. Im Self-Etch-Verfahren wurden

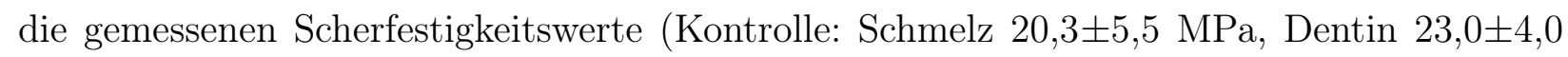
$\mathrm{MPa}$ ) von allen simulierten Reparatur-Konditionierungsverfahren - mit Ausnahme des Universalprimers - beeinflusst $(\mathrm{p}<0,001)$. Es zeigten sich überwiegend adhäsive und gemischte Versagensmuster. Kohäsive Versagensmuster traten nur bei nicht-kontaminierten Oberflächen auf. Die Parameter der Weibull-Verteilung zeigten, dass ein Großteil der simulierten Reparatur-Konditionierungsverfahren zu einer Reduktion der charakteristischen Haftkräfte $\left(\sigma_{0}\right)$ führte. Der Weibull-Modul $m$ war zumeist in den Kontrollgruppen (keine Kontamination) am größten. 
Die rasterelektronenmikroskopischen Aufnahmen zeigten, dass eine Sandstrahlung das Schmelz-Ätzmuster zerstört bzw. das mittels Phosphorsäure-Ätzung freigelegte Kollagennetzwerk entfernt. Ohne nachfolgende Phosphorsäure-Applikation (im Self-Etch-Verfahren) verblieben Partikel des Strahlmittels auf den Oberflächen. Die Applikation von Flusssäure bzw. des selbstätzenden Keramikprimers führte zur Ausbildung einer amorphen Oberflächenschicht, die sich nicht mehr durch nachfolgende Phosphorsäure-Ätzung entfernen ließ.

\section{Diskussion}

Der überwiegende Anteil der befragten Zahnärzt*innen integriert Reparaturmaßnahmen in die tägliche Behandlungspraxis. Nur ein sehr kleiner Anteil lehnt Reparaturmaßnahmen grundsätzlich ab bzw. erachtet Reparaturmaßnahmen lediglich als eine temporäre Maßnahme. Besonders häufig werden partiell insuffiziente Kompositrestaurationen und indirekte Restaurationen repariert. Auffällig ist, dass je häufiger Reparaturmaßnahmen durchgeführt werden, desto besser wird ihre Erfolgsrate eingeschätzt. Diese Ergebnisse fügen sich in die internationale Situation ein: Aus der verbreiteten Lehre von Reparaturmaßnahmen resultiert, dass diese von Zahnärzt*innen oft angewandt werden und ihr Gebrauch in den letzten Jahren signifikant anstieg. Basierend auf einer systematischen Übersichtsarbeit gaben $72 \%$ von insgesamt 7.228 befragten Zahnärzt*innen an, bei ihren Patient*innen Reparaturmaßnahmen durchzuführen (Kanzow et al. 2017b).

Die Rücklaufquote der vorliegenden Umfrage betrug zwar nur 28\%, aber vergleichbare Studien lieferten ähnliche Werte zwischen 9 und 21\% (Naumann et al. 2006; Müller et al. 2008; Ommerborn et al. 2009; Hertrampf et al. 2012; Mitov et al. 2014; Willershausen et al. 2014). Aufgrund des anonymen Studiendesigns war es nicht möglich, Zahnärzt*innen individuell an ihre Studienteilnahme zu erinnern. Da die demographischen Daten der teilgenommenen Zahnärzt*innen die Mitgliederstatistik der Zahnärztekammer Niedersachsen sowie der Bundeszahnärztekammer gut widerspiegeln, kann die Umfrage als repräsentativ erachtet werden. Bei der Betrachtung der demographischen Faktoren konnte allerdings keine eindeutige Korrelation mit dem Reparaturverhalten von Zahnärzt*innen gefunden und somit kein spezifisches Muster für oder gegen die Anwendung von Reparaturmaßnahmen identifiziert werden. In der Literatur beschriebene Zusammenhänge zwischen demographischen Daten und zahnärztlichen Therapieentscheidungen beziehen sich auf Therapieentscheide im Allgemeinen, unab- 
hängig vom Behandlungskonzept der Reparaturen (Vidnes-Kopperud et al. 2009; Riley et al. 2011; Gordan et al. 2012; Kakudate et al. 2012). Jedoch spielten - in Übereinstimmung mit der Literatur - zahn- bzw. restaurationsbezogene Variablen bei der Durchführung von Reparaturen eine Rolle. Während die befragten Zahnärzt*innen angaben, überwiegend Restaurationen mit funktionellen Versagensmustern zu reparieren, nennen amerikanische Studien vor allem Sekundärkaries als Indikation für Reparaturen (Gordan et al. 2014). Im Hinblick auf die Durchführung von Reparaturen gaben die befragten Zahnärzt*innen an, hauptsächlich Komposit für die Anfertigung von Reparaturrestaurationen anzuwenden. Die genauen Techniken, Materialien und Vorbehandlungsmaßnahmen unterschieden sich jedoch. Zahnärzt*innen, die spezifische Techniken (z.B. Sandstrahlung) anwenden, sahen Reparaturrestaurationen jedoch häufiger als permanente Restaurationen an. Da ein derartiges Vorgehen (mechanische Anrauung, Sandstrahlung, Applikation eines Silans und Adhäsivsystems) invitro mit erhöhten Haftwerten einhergeht, kann vermutet werden, dass Zahnärzt*innen bei der Anwendung dieser Techniken höhere Überlebensraten der Reparaturrestaurationen beobachteten und Reparaturen infolge besser bewerten.

Bisher fokussierte sich keine Reparatur-Studie unmittelbar auf die Patient*innensicht - abgesehen von der Analyse von Patient*inneninformationen zum Thema „Reparaturen“ auf Webseiten von Zahnärzt*innen (Kanzow et al. 2020). Die Patient*innenakzeptanz wurde immer nur indirekt über die behandelnden Zahnärzt*innen ermittelt. Dabei beschrieben Zahnärzt*innen die Patient*innenakzeptanz gegenüber Reparaturrestaurationen mit etwa 90\% als sehr hoch (Blum et al. 2005; Kanzow et al. 2017a; Reineix et al. 2019). Allerdings scheint die Patient*innenakzeptanz gegenüber Reparaturmaßnahmen von der Frage abzuhängen, ob reparierte Restaurationen vom Zeitpunkt der Reparatur an genauso lange halten wie eine neue, d.h. vollständig ersetzte Restauration. In der vorliegenden Studie wurde die Patient*innenakzeptanz von den befragten Zahnärzt*innen ebenfalls als hoch eingeschätzt. Aus Sicht der Zahnärzt*innen akzeptierten hingegen etwa ein Drittel der Patient*innen eine Reparatur nur dann, wenn ihre Haltbarkeit mit der einer Ersatzrestauration vergleichbar ist. Ähnliche Daten zeigten sich für die Patient*innenakzeptanz in der Schweiz (Kanzow et al. 2017a).

Neben den eingangs erwähnten prospektiven klinischen Studien untersuchten mehrere retrospektive Studien den Einfluss von Reparaturmaßnahmen auf die Überlebensraten von 
Komposit- und Amalgamrestaurationen bei bleibenden Zähnen (Opdam et al. 2012; Casagrande et al. 2017; van de Sande et al. 2018) bzw. von Kompositrestaurationen bei Milchzähnen (Ruiz et al. 2020). Es zeigte sich in allen Studien, dass Reparaturmaßnahmen das Überleben der nachbeobachteten Restaurationen verlängern konnten. Von den genannten Studien untersuchte jedoch nur eine die Lebensdauer von Reparaturrestaurationen ab dem Zeitpunkt der Reparatur (Opdam et al. 2012). Als Vergleich dienten allerdings Erstrestaurationen, die keine Ersatzrestaurationen im eigentlichen Sinne darstellen (Opdam et al. 2010). Dabei wiesen die reparierten Restaurationen eine mittlere jährliche Versagensrate über fünf Jahre von 6,0\% (reparierte Kompositrestaurationen) bzw. 10,4\% (reparierte Amalgamrestaurationen) auf. Hingegen wiesen die neu angefertigten Restaurationen deutlich niedrigere Versagensraten auf (1,8\% für Kompositrestaurationen und 1,2\% für Amalgamrestaurationen). Auch in der vorliegenden Studie konnte gezeigt werden, dass Reparaturmaßnahmen das Überleben von partiell insuffizienten Restaurationen verlängern können. Die Überlebensrate von Reparaturrestaurationen war jedoch mit denen von Ersatzrestaurationen vergleichbar: Für den Zielparameter „Success“, d.h. keine Notwendigkeit für eine weitere Intervention, betrug die mittlere jährliche Versagensrate über einen Zeitraum von zehn Jahren 8,0\% bei Reparaturrestaurationen und 7,0\% bei Ersatzrestaurationen.

Auch bei indirekten Restaurationen lassen sich Reparaturmaßnahmen erfolgreich anwenden: In der Befragung von Zahnärzt*innen in Deutschland zeigte sich, dass der Verschluss einer endodontischen Zugangskavität die am häufigsten genannte Indikation für Reparaturmaßnahmen an indirekten Restaurationen darstellt. Diesbezüglich zeigte die Studie zur Lebensdauer reparierter Kronen und Ankerrestaurationen, dass Reparaturmaßnahmen das Überleben einer indirekten Restauration nach endodontischen Behandlungsmaßnahmen verlängern können.

Aufgrund des retrospektiven Studiendesigns konnten bei beiden Studien, die die Lebensdauer von Restaurationen ermittelten, keine studienbedingten Visiten durchgeführt werden. Folglich waren nur eingeschränkt Informationen bezüglich der genauen Versagensgründe sowie der klinischen Situation und den verwendeten Techniken und Materialien verfügbar. Beispielsweise könnten Ersatzrestaurationen in schwierigeren Situationen oder bei Patient*innen mit erhöhtem Kariesrisiko vermehrt durchgeführt worden sein. Zudem wurden die Restaurationen von verschiedenen Zahnärzt*innen bzw. Studierenden unter Aufsicht erfahrener Zahnärzt*innen angefertigt und nachuntersucht. Darüber hinaus besteht die Möglichkeit, 
dass Patient*innen in der Zwischenzeit ebenfalls auch andere Zahnärzt*innen aufsuchten, wodurch Restaurationen ohne unser Wissen ggf. repariert oder ersetzt wurden. Als Stärke kann hingegen die große Fallzahl von initial 8.542 Kompositrestaurationen bei 3.239 Patient*innen und der lange Nachbeobachtungszeitraum von bis zu 18,9 Jahren genannt werden. Außerdem wurden alle Behandlungen nach den jeweils aktuellen wissenschaftlichen Standards durchgeführt, sodass die Datengrundlage das Überleben von initialen Restaurationen sowie Reparatur- und Ersatzrestaurationen adäquat widerspiegeln dürfte.

Während sich die Reparatur von Kompositrestaurationen als effektiver $(+0,7$ Jahre) und nur minimal teurer ( +5 Euro) als die Erneuerung erwies, waren Reparaturen von Amalgamrestaurationen sowohl effektiver $(+0,7$ Jahre) als auch deutlich teurer $(+141$ Euro). Jedoch waren Reparaturmaßnahmen bei großen (4-flächigen) Kompositrestaurationen kostenwirksam. Dies lässt sich damit begründen, dass das Versagensrisiko von Ersatzrestaurationen bei ausgedehnten Restaurationen größer als bei kleineren Restaurationen ist (Da Rosa Rodolpho et al. 2011). Im Falle einer wiederholten Reparaturmöglichkeit erwiesen sich Reparaturmaßnahmen von Kompositrestaurationen ebenfalls als kostenwirksam. Die höheren Kosten von Reparaturen im Falle von partiell insuffizienten Amalgamrestaurationen lassen sich darauf zurückführen, dass die Anfertigung einer neuen Amalgamrestauration im Rahmen des deutschen Gesundheitssystems deutlich günstiger als die Anfertigung einer Kompositrestauration ist. Hierdurch ist der Kostenunterschied zwischen einer Erneuerung mit Amalgam und der Reparatur mit Komposit geringer. Zudem wurde für neue Amalgamrestaurationen eine längere Lebensdauer als für Reparaturen mit Komposit angenommen (Opdam et al. 2012). Jedoch dürften heutzutage aufgrund von Sicherheitsbedenken und der angestrebten reduzierten Anwendung von Amalgam defekte Amalgamrestaurationen im Falle einer Neuanfertigung eher mit Komposit als mit Amalgam versorgt werden (Kielbassa et al. 2014; Kopperud et al. 2016).

Die Ergebnisse der Kostenwirksamkeitsanalyse sind in hohem Maße von den Ergebnissen (Überlebensraten und Versagenswahrscheinlichkeiten) der eingeschlossenen Studien und der Qualität der für die Kalkulationen verwendeten Daten abhängig. Zum Zeitpunkt der Studiendurchführung hatten nur wenige Studien das Versagensrisiko von Reparatur- und Ersatzrestaurationen miteinander verglichen. Zudem erfolgte die Zuteilung auf die beiden Studienarme „Reparatur“ und „Ersetzen“ nicht randomisiert (Smales und Hawthorne 2004; Gordan 
et al. 2011; Opdam et al. 2012). Darüber hinaus unterscheiden sich die angewandten Indikationen für Reparaturen zwischen den Studien deutlich, was auf zum damaligen Zeitpunkt fehlende Richtlinien im Hinblick auf die Anwendung von Reparaturmaßnahmen zurückzuführen ist (Hickel et al. 2013).

Die unter Zahnärzt*innen in Deutschland durchgeführte Umfrage zeigte große Unterschiede bei der Indikation und Vorgehensweise von Reparaturrestaurationen. Daher ergibt sich die Notwendigkeit, einheitliche Behandlungsempfehlungen für die Anwendung von Reparaturmaßnahmen zu erstellen. Im Jahr 2019 verabschiedete der Weltverband der Zahnärzt*innen (FDI World Dental Federation) eine erste Handlungsempfehlung zur Durchführung von Reparaturen: Bei der Anwendung von Reparaturmaßnahmen sollte eine Kombination physikalischer und chemischer Konditionierungsverfahren genutzt werden. Nach der Anwendung physikalischer Konditionierungsmaßnahmen wird die anschließende Applikation von Phosphorsäure auf mitbeteiligte Zahnhartsubstanz empfohlen (FDI World Dental Federation 2020). Die Studie zu den Auswirkungen gängiger Reparatur-Konditionierungsverfahren auf die Schmelz- und Dentinhaftung zeigte, dass diese - ausgenommen von dem untersuchten Universalprimer - einen negativen Effekt auf die Haftung an der oftmals mitbetroffenen Zahnhartsubstanz ausüben. Daher sollte bei der Anfertigung von Reparaturrestaurationen eine Kontamination von Schmelz und Dentin mit physikalischen und chemischen Konditionierungsverfahren vermieden werden. Kommt es dennoch zu einer Kontamination durch die Sandstrahlung, kann - im Einklang mit den Empfehlungen des FDI - eine nachfolgende Applikation von Phosphorsäure bei der Anwendung eines Adhäsivs im Etch\&Rinse-Verfahren die negativen Auswirkungen auf die Schmelz- und Dentinhaftung reduzieren.

Ein alternativ in der Literatur beschriebener Ansatz besteht in einem zweischrittigen Verfahren, bei dem zunächst nur die beteiligte Zahnhartsubstanz mit Komposit abgedeckt wird. Erst anschließend wird die Oberfläche der beteiligten Restauration und des Komposits konditioniert (Haller 2019). Vor dem Hintergrund der Studie scheint ein derartiges Vorgehen sinnvoll, um sowohl die Zahnhartsubstanz als auch die Restauration optimal vorzubehandeln. 


\section{Literaturverzeichnis}

Blum IR, Newton JT, Wilson NH (2005): A cohort investigation of the changes in vocational dental practitioners' views on repairing defective direct composite restorations. $\mathrm{Br}$ Dent $J \underline{199}$, S27-S30

Casagrande L, Laske M, Bronkhorst EM, Huysmans MCDNJM, Opdam NJM (2017): Repair may increase survival of direct posterior restorations - a practice based study. J Dent $\underline{64}$, $30-36$

Chang JC, Koh SH, Powers JM, Duong JH (2002): Tensile bond strengths of composites to a gold-palladium alloy after thermal cycling. J Prosthet Dent $\underline{87}, 271-276$

Da Rosa Rodolpho PA, Donassollo TA, Cenci MS, Loguercio AD, Moraes RR, Bronkhorst EM, Opdam NJ, Demarco FF (2011): 22-Year clinical evaluation of the performance of two posterior composites with different filler characteristics. Dent Mater $\underline{27}, 955-963$

Doméjean S, Léger S, Maltrait M, Espelid I, Tveit AB, Tubert-Jeannin S (2015): Changes in occlusal caries lesion management in France from 2002 to 2012: a persistent gap between evidence and clinical practice. Caries Res $\underline{49}$, 408-416

Eltahlah D, Lynch CD, Chadwick BL, Blum IR, Wilson NHF (2018): An update on the reasons for placement and replacement of direct restorations. J Dent $\underline{72}, 1-7$

Estay J, Martín J, Viera V, Valdivieso J, Bersezio C, Vildosola P, Mjor IA, Andrade MF, Moraes RR, Moncada G, Gordan VV, Fernández E (2018): 12 years of repair of amalgam and composite resins: a clinical study. Oper Dent $\underline{43}, 12-21$

FDI World Dental Federation (2020): Repair of restorations: Adopted by the General Assembly: September 2019, San Francisco, United States of America. Int Dent $J \underline{70}, 7-8$

Fernández E, Martín J, Vildósola P, Oliveira Junior OB, Gordan V, Mjor I, Bersezio C, Estay J, de Andrade MF, Moncada G (2015): Can repair increase the longevity of composite resins? Results of a 10-year clinical trial. J Dent $\underline{43}, 279-286$

Flury S, Dulla FA, Peutzfeldt A (2019): Repair bond strength of resin composite to restorative materials after short- and long-term storage. Dent Mater $\underline{35}$, 1205-1213 
Frankenberger R, Vosen V, Krech M, Krämer N, Braun A, Roggendorf MJ (2014): Darf's ein bisschen weniger sein? Quintessenz $\underline{65}, 541-545$

GKV-Spitzenverband: Kennzahlen der gesetzlichen Krankenversicherung: Versicherte je System in Prozent. GKV-Spitzenverband, Berlin, 2019. https://www.gkvspitzenverband.de/presse/zahlen_und_grafiken/zahlen_und_grafiken.jsp\#lightbox; letzter Zugriff am 26.06.2020

Gordan VV, Riley JL 3rd, Blaser PK, Mondragon E, Garvan CW, Mjör IA (2011): Alternative treatments to replacement of defective amalgam restorations: results of a seven-year clinical study. J Am Dent Assoc 142, 842-849

Gordan VV, Riley JL 3rd, Geraldeli S, Rindal DB, Qvist V, Fellows JL, Kellum HP, Gilbert GH, The DPBRN Collaborative Group (2012): Repair or replacement of defective restorations by dentists in The Dental PBRN. J Am Dent Assoc $\underline{143}$, 593-601

Gordan VV, Riley JL 3rd, Geraldeli S, Williams OD, Spoto JC 3rd, Gilbert GH, National Dental PBRN Collaborative Group (2014): The decision to repair or replace a defective restoration is affected by who placed the original restoration: findings from the National Dental PBRN. J Dent $\underline{42}, 1528-1534$

Haller B (2019): Defekte Restaurationen: reparieren statt flicken. Der Freie Zahnarzt $\underline{63}$, 68-79

Hertrampf K, Wenz HJ, Koller M, Wiltfang J (2012): Comparing dentists' and the public's awareness about oral cancer in a community-based study in Northern Germany. J Craniomaxillofac Surg $\underline{40}, 28-32$

Hickel R, Brushaver K, Illie N (2013): Repair of restorations - Criteria for decision making and clinical recommendations. Dent Mater $\underline{29}, 28-50$

Kakudate N, Sumida F, Matsumoto Y, Manabe K, Yokoyama Y, Gilbert GH, Gordan VV (2012): Restorative treatment thresholds for proximal caries in dental PBRN. J Dent Res $\underline{91}, 1202-1208$

Kanzow P, Baxter S, Rizk M, Wassmann T, Wiegand A (2019a): Effectiveness of a universal adhesive for repair bonding to composite and amalgam. J Oral Sci $\underline{61}$, 343-350 
Kanzow P, Büttcher AF, Wiegand A, Schwendicke F (2020): Information regarding repair restorations on German dentists' websites. J Med Internet Res 22 , e17250

Kanzow P, Dieckmann P, Hausdörfer T, Attin T, Wiegand A, Wegehaupt FJ (2017a): Repair restorations: questionnaire survey among dentists in the Canton of Zurich, Switzerland. Swiss Dent J $\underline{127}$, 300-305

Kanzow P, Wiegand A (2020): Teaching of composite restoration repair: trends and quality of teaching over the past 20 years. J Dent $\underline{95}, 103303$

Kanzow P, Wiegand A, Göstemeyer G, Schwendicke F (2017b): Understanding the management and teaching of dental restoration repair: systematic review and meta-analysis of surveys. J Dent $\underline{69}, 1-21$

Kanzow P, Wiegand A, Schwendicke F, Göstemeyer G (2019b): Same, same, but different? A systematic review of protocols for restoration repair. J Dent $\underline{86}, 1-16$

Kanzow P, Wiegand A, Wilson NHF, Lynch CD, Blum IR (2018): Contemporary teaching of restoration repair at dental schools in Germany - close to universality and consistency. $J$ Dent $\underline{75}, 121-124$

Kielbassa AM, Lynch CD, Wilson NH (2014): The Minamata convention: the beginning of the (amalgam-free) future? Quintessence Int $\underline{45}, 547-548$

Kopperud SE, Staxrud F, Espelid I, Tveit AB (2016): The Post-Amalgam Era: Norwegian Dentists' Experiences with Composite Resins and Repair of Defective Amalgam Restorations. Int J Environ Res Public Health $\underline{13}, 441$

KZBV: Konservierende und chirurgische Leistungen. In: Kassenzahnärztliche Bundesvereinigung (Hrsg.): Jahrbuch 2019. KZBV, Köln, 2019.

Manhart J, Chen H, Hamm G, Hickel R (2004): Buonocore Memorial Lecture. Review of the clinical survival of direct and indirect restorations in posterior teeth of the permanent dentition. Oper Dent 29, 481-508

Martin J, Fernandez E, Estay J, Gordan VV, Mjor IA, Moncada G (2013): Minimal invasive treatment for defective restorations: five-year results using sealants. Oper Dent $\underline{38}, 125-133$ 
Mitov G, Dörr M, Nothdurft FP, Draenert F, Pospiech PR (2014): Post-endodontic treatment of incisors and premolars among dental practitioners in Saarland: an interactive web-based survey. Clin Oral Invest $\underline{19}, 1029-1037$

Müller MP, Hansel M, Stehr SN, Weber S, Koch T (2008): A state-wide survey of medical emergency management in dental practices: incidence of emergencies and training experience. Emerg Med J 모, 296-300

Naumann M, Kiessling S, Seemann R (2006): Treatment concepts for restoration of endodontically treated teeth: a nationwide survey of dentists in Germany. J Prosthet Dent $\underline{96}$, $332-338$

Oliveira DC, Warren JJ, Levy SM, Kolker J, Qian F, Carey C (2016): Acceptance of minimally invasive dentistry among US dentists in Public Health Practices. Oral Health Prev Dent $\underline{14}, 501-508$

Ommerborn MA, Kollmann C, Handschel J, Depprich RA, Lang H, Raab WHM (2009): A survey on German dentists regarding the management of craniomandibular disorders. Clin Oral Invest $\underline{14}, 137-144$

Opdam NJ, Bronkhorst EM, Loomans BA, Huysmans MC (2010): 12-year survival of composite vs. amalgam restorations. J Dent Res $\underline{89}$, 1063-1067

Opdam NJ, Bronkhorst EM, Loomans BA, Huysmans MC (2012): Longevity of repaired restorations: a practice based study. J Dent $\underline{40}, 829-835$

Özcan M, Koolman C, Aladag A, Dündar M (2011): Effects of different surface conditioning methods on the bond strength of composite resin to amalgam. Oper Dent $\underline{36}, 318-325$

Özcan M, Niedermeier W (2002): Clinical study on the reasons for and location of failures of metal-ceramic restorations and survival of repairs. Int J Prosthodont $\underline{15}, 299-302$

Qvist V: Longevity of restorations: the 'death spiral' In: Fejerskov O, Nyvad B, Kidd E. (Hrsg.): Dental caries: the disease and its clinical management. 3. Auflage; Wiley Blackwell, Oxford, 2015, 387-401.

Raedel M, Hartmann A, Priess HW, Bohm S, Samietz S, Konstantinidis I, Walter MH (2017): Re-interventions after restoring teeth - mining an insurance database. J Dent $\underline{57}, 14-19$ 
Reineix E, Holmgren C, Muller-Bolla M, Chadelat A, Volgenant C, De Soet H, Kopperud SE, Staxrud F, Seux D, Doméjean S (2019): Réparation des restaurations défectueuses: connaissances et attitudes thérapeutiques en France. CDF 1842-1843, 35-41

Riley JL, Gordan VV, Rouisse KM, McClelland J, Gilbert GH (2011): Differences in male and female dentists' practice patterns regarding diagnosis and treatment of dental caries. J Am Dent Assoc 142, 429-440

Ruiz LF, Nicoloso GF, Franzon R, Lenzi TL, de Araujo FB, Casagrande L (2020): Repair increases the survival of failed primary teeth restorations in high-caries risk children: a university-based retrospective study. Clin Oral Invest 24, 71-77

Schriever A, Blum IR, Wilson NHF, Heidemann D (2003): Reparatur von Kompositfüllungen als Bestandteil der studentischen Ausbildung. Dtsch Zahnärztl Z 모, 277-279

Schwendicke F (2019): Less is more? The long-term health and cost consequences resulting from minimal invasive caries management. Dent Clin North Am $\underline{63}, 737-749$

Shafiei F, Fattah Z, Kiomarsi N, Dashti MH (2019): Influence of primers and additional resin layer on zirconia repair bond strength. J Prosthodont $\underline{28}, 826-832$

Smales RJ, Hawthorne WS (2004): Long-term survival of repaired amalgams, recemented crowns and gold castings. Oper Dent $\underline{29}$, 249-253

Tsujimoto A, Barkmeier WW, Takamizawa T, Wilwerding TM, Latta MA, Miyazaki M (2017): Interfacial characteristics and bond durability of universal adhesive to various substrates. Oper Dent $\underline{42}$, E59-E70

van de Sande FH, Moraes RR, Elias RV, Montagner A. F. Rodolpho PA, Demarco FF, Cenci MS (2018): Is composite repair suitable for anterior restorations? A long-term practicebased clinical study. Clin Oral Invest 23, 2795-2803

Veríssimo AH, Duarte Moura DM, de Oliveira Dal Piva AM, Bottino MA, de Fátima Dantas de Almeida L, da Fonte Porto Carreiro A, de Assunção E, Souza RO (2019): Effect of different repair methods on the bond strength of resin composite to CAD/CAM materials and microorganisms adhesion: an in situ study. J Dent $\underline{93}, 103266$ 
Vidnes-Kopperud S, Tveit AB, Espelid I (2011): Changes in the treatment concept for approximal caries from 1983 to 2009 in Norway. Caries Res $\underline{45}, 113-120$

Vidnes-Kopperud S, Tveit AB, Gaarden T, Sandvik L, Espelid I (2009): Factors influencing dentists' choice of amalgam and tooth-colored restorative materials for class II preparations in younger patients. Acta Odontol Scand $\underline{67}, 74-79$

Willershausen I, Wolf TG, Schmidtmann I, Berger C, Ehlers V, Willershausen B, Briseño B (2014): Survey of root canal irrigating solutions used in dental practices within Germany. Int Endod J $\underline{48}, 654-660$

World Health Organization: Sugars and dental caries: technical information note. WHO, Geneva, 2017. http://apps.who.int/iris/bitstream/10665/259413/1/WHO-NMHNHD-17.12-eng.pdf?ua=1; letzter Zugriff am 26.06.2020 


\section{Zusammenfassung}

Die vorliegende Studienserie befragte Zahnärzt*innen im Hinblick auf die Anwendung von Reparaturmaßnahmen, untersuchte klinische Erfolgsraten für direkte und indirekte Restaurationen, zeigte gesundheitsökonomische Implikationen im Zusammenhang mit Reparaturmaßnahmen auf und generierte praktische Handlungsempfehlungen für die Durchführung von Reparaturen.

Es wurde festgestellt, dass Zahnärzt*innen in Deutschland Reparaturmaßnahmen häufig anwenden und hinsichtlich ihrer Erfolgsrate positiv bewerten. Allerdings gibt es große Unterschiede bei der Indikationsstellung und Vorgehensweise. Reparaturmaßnahmen sind geeignet, das Überleben von partiell insuffizienten direkten und indirekten Restaurationen zu verlängern. Die Lebensdauer von Reparaturrestaurationen ist mit denen von Ersatzrestaurationen vergleichbar und reparierte Kompositrestaurationen bedürfen keiner häufigeren und/oder früheren Reinterventionen. Somit kann durch den Einsatz von Reparaturmaßnahmen auch der betroffene Zahn selbst länger erhalten werden. Im Sinne eines verlängerten Zahnerhalts sind Reparaturmaßnahmen bei verschiedenen Restaurationsmaterialien wirksam, jedoch nicht zwangsläufig günstiger. Reparaturen von partiell insuffizienten Kompositrestaurationen waren nur geringfügig teurer, während Reparaturen von partiell insuffizienten Amalgamrestaurationen mit einem deutlich höheren Kostenaufwand verbunden waren. Insbesondere bei initial bereits großen Kompositrestaurationen und Kompositrestaurationen mit Sekundärkaries waren Reparaturmaßnahmen kostenwirksam. Die Anwendung von Reparaturmaßnahmen erfordert Konditionierungsverfahren, die auf das jeweilige Restaurationsmaterial abgestimmt sind. Die Ergebnisse belegen, dass während der Anfertigung von

Reparaturrestaurationen eine Kontamination der oftmals mitbeteiligten Zahnhartsubstanz durch Reparatur-Konditionierungsverfahren zu vermeiden ist. Andernfalls führen die meisten Verfahren zu reduzierten Haftwerten auf der Zahnhartsubstanz.

Auf Basis der vorgelegten Studienserie lässt sich feststellen, dass Reparaturmaßnahmen geeignet sind, das Überleben partiell insuffizienter Restaurationen und der betroffenen Zähne zu verlängern. Reparaturmaßnahmen stellen ein vollwertiges und minimalinvasives Therapiekonzept in der modernen Zahnmedizin dar. Sie sollten daher - soweit möglich - vorrangig Anwendung finden. 


\section{Anhang}

Im Folgenden sind die Kopien der dieser Schrift zugrunde liegenden Originalarbeiten beigefügt. Die Urheberrechte stellen sich wie folgt dar:

Reprinted by permission from Springer Nature Customer Service Centre GmbH: Springer Nature Clinical Oral Investigations, Attitudes, practice, and experience of German dentists regarding repair restorations, volume 21, 2017, pages 1087-1093, Kanzow P, Hoffmann R, Tschammler C, Rödig T, Wiegand A, Springer-Verlag Berlin Heidelberg 2016.

Reprinted from Dental Materials, volume 36, Kanzow P, Wiegand A, Retrospective analysis on the repair vs. replacement of composite restorations, pages 108-118, 2020, with permission from Elsevier. https://dx.doi.org/10.1016/j.dental.2019.11.001.

Reprinted from Journal of Endodontics, volume 46, Wiegand A, Kanzow P, Effect of repairing endodontic access cavities on survival of single crowns and retainer restorations, pages 376-382, 2020, with permission from Elsevier. https://dx.doi.org/10.1016/j.joen.2019.11.012.

Reprinted from Journal of Dentistry, volume 54, Kanzow P, Wiegand A, Schwendicke F, Cost-effectiveness of repairing versus replacing composite or amalgam restorations, pages 41-47, 2016, with permission from Elsevier. https://dx.doi.org/10.1016/j.jdent.2016.08.008.

Kanzow et al. 2020. Repair surface conditioning measures affect enamel and dentin bond strength. J Op Dent, Epub ahead of print. Used by permission. ㄷ Operative Dentistry, Inc. Transmission or reproduction of protected items beyond that allowed by fair use requires the written permission of Operative Dentistry, Inc. 


\title{
Attitudes, practice, and experience of German dentists regarding repair restorations
}

\author{
Philipp Kanzow $^{1}$ - Robin Hoffmann ${ }^{1}$ - Claudia Tschammler ${ }^{1}$. Jochen Kruppa ${ }^{2}$. \\ Tina Rödig ${ }^{1} \cdot$ Annette Wiegand $^{1}$
}

Received: 17 November 2015 / Accepted: 20 May 2016 / Published online: 2 June 2016

(C) Springer-Verlag Berlin Heidelberg 2016

\begin{abstract}
Objectives The aim of the present study was to perform a representative survey among German dentists about attitudes, practice, and experience regarding single-tooth repair restorations.

Materials and methods An anonymous questionnaire was designed and mailed to all registered dentists in Lower Saxony $(n=6600)$. Twenty-eight percent were returned $(n=1852)$, and $n=1805$ could be analyzed. Statistical analyses were done by Wilcoxon signed-rank tests, Kruskal-Wallis tests, and ordered logistic regressions $(p<0.05)$.

Results Only $2.2 \%$ of the dentists declared to never perform repair restorations. Composite restorations were repaired significantly more often than all other materials. Frequency of performing repair restorations was partially associated to dentist-related factors. The decision for repairing a restoration was dependent on several tooth- and restoration-associated variables. The main indications for repair were the partial loss of restoration or adjacent tooth structure as well as chipping and endodontic access cavities of crowns. Repair restorations were mostly done with composite using various different preconditioning techniques. Overall patients' acceptance was reported to be high. Most of the dentists considered repair restorations as permanent restoration with a moderate to high longevity. Estimated success of repair restorations depended
\end{abstract}

Philipp Kanzow

philipp.kanzow@med.uni-goettingen.de

1 Department of Preventive Dentistry, Periodontology and Cariology, University Medical Center Göttingen, Robert-Koch-Str. 40, 37075 Göttingen, Germany

2 Department of Medical Statistics, University Medical Center Göttingen, Humboldtallee 32, Göttingen 37073, Germany significantly on the dentists' experiences (frequency and techniques of repair restorations).

Conclusions Repair restorations were often performed and were well accepted by dentists and patients, but indications for repair restorations as well as applied materials and techniques varied distinctly.

Clinical relevance Repairs of single-tooth restorations are well accepted and frequently performed, but indications, techniques, and materials require further research.

Keywords Questionnaire $\cdot$ Repair restorations $\cdot$ Experience $\cdot$ Patient's acceptance $\cdot$ Success

\section{Introduction}

As any restoration has a finite life span, repair of partially defective restorations has become an interesting approach to delay or avoid a cascade of replacement cycles, which goes along with further removal of hard tooth tissue [1] and therefore might compromise the survival of the tooth itself over time.

In recent years, repair materials and techniques were intensively studied resulting in an increased frequency of scientific publications [2]. Based on a systematic review of the literature, criteria for decision making when and how to repair defective restorations were developed. Depending on the kind of restorative material, clinical recommendations usually comprise smoothening and cleaning of the repair surface, surface pretreatment by mechanical roughening, sandblasting (metal, composite) or hydrofluoric acid etching (ceramic), as well as application of silane, adhesive, and composite [2].

As repair restorations are no longer considered as "patchwork dentistry", but rather as a scientifically proven approach to manage failed restorations, restoration repair is meanwhile taught in most universities in North America and Europe - including 
Germany [3-11]. While in 2000/2001, only $50 \%$ of the universities in Germany had included repair restorations in their curricula, almost all universities taught restoration repair 10 years later [3].

However, it is not clear if and how repair of partially defective restorations is implemented in daily practice. Thus, the aim of the present questionnaire survey was to analyze the attitudes, practice, and experience of German dentists regarding repair restorations.

\section{Materials and methods}

\section{Design and validation of the questionnaire}

An anonymous questionnaire with nine-item batteries was designed, using closed response modes with binary or multiple choice and contingency questions (Table 1).

Internal consistency and reliability were tested in a pilot study involving 15 dentists, who completed the questionnaire twice within 2 weeks. Test-retest reliability was found to be substantial (mean Cohen's kappa 0.628, Kendall's tau 0.666, and Cronbach's alpha 0.776 ). The questionnaire could be completed in less than $10 \mathrm{~min}$.

The questionnaire was approved by the local ethics committee (no. 18/11/14) and mailed by the state dental regulatory body together with personalized cover letters and stamped return envelopes to all registered dentists in Lower Saxony $(n=6600)$. The survey was closed 6 weeks after delivery of the questionnaires. Non-responders could not be reminded due to the anonymous character of this study.

\section{Statistical analysis}

Data from the returned questionnaires were transferred into a database (Excel for Mac 2011, Microsoft, Redmond, Washington, USA) by two different examiners. The inter-

Table 1 Questionnaire design and contained item batteries

\begin{tabular}{ll}
\hline Item battery & Content \\
\hline 1 & Demographic data \\
2 & Frequency of repairs for different restoration materials \\
3 & Reasons for repairs \\
4 & Decision making criteria to assess repairability of \\
& restorations \\
5 & Restoration failures suitable for repairs \\
6 & Restorative materials used to perform repairs \\
7 & Techniques and materials for preconditioning of the repair \\
8 & surfaces \\
9 & Patient acceptance of repairs \\
\hline
\end{tabular}

examiner reliability was tested in a subgroup of 20 questionnaires (mean Cohen's kappa 0.952, Kendall's tau 0.978, and Cronbach's alpha 0.986).

Analyses were performed using the software R (version 3.0.3, www.r-project.com). Wilcoxon signed-rank tests were used to compare repair frequencies of different restoration materials (amalgam, composite, ceramic, metal, crowns); $p$ values were adjusted according to Bonferroni-Holm. The influence of gender, specialization/field of activity, practice location (rural areas, towns, cities greater than 100,000 inhabitants), and practice setting (single practitioner, private practices with multiple dentists, university dental schools) on repair frequencies was assessed using Kruskal-Wallis tests. The correlation between dentists' age and repair frequencies was analyzed by Kendall's rank correlation coefficient. Finally, ordered logistic regressions were used to evaluate the effect of repair frequencies and different repair techniques on the dentists' rating of repaired restorations. The overall level of significance was set at $p<0.05$.

\section{Results}

The response rate amounted to $28 \%(n=1852)$, of which $n=1805$ questionnaires (726 females, 1070 males, and 9 who did not specified their gender) could be included in the analysis. Forty-seven of the responders identified themselves as non-active dentists (e.g., orthodontists, surgeons) and did not answer the questionnaire. Item non-response was below $5 \%$; all responded items were considered for analysis.

\section{Demographics}

The mean age of the participants was $49.3( \pm 11.1)$ years; the average time from receiving their license to practice dentistry (“Approbation”) amounted to $21.6( \pm 11.1)$ years. Most participants worked in private practices with multiple dentists $(59.1 \%)$, while $39.4 \%$ worked as single practitioners and $1.5 \%$ were employed at university dental schools. Forty-two percent of the dentists worked in rural areas, $36.0 \%$ in towns, and $22.1 \%$ in cities greater than 100,000 inhabitants. Forty percent of the participating dentists declared to have a specialization or to be active in one or more specific fields of dentistry. Implantologists represented the largest proportion of specialists $(37.4 \%)$, followed by specializations/field of activities in periodontology (17.4\%) and endodontics (13.3\%).

\section{Frequency of repairs for different restorations}

Only $2.2 \%$ of all responders reported to never perform repair restorations. In general, composite restorations were repaired most frequently (93.4\%), followed by ceramic restorations $(85.5 \%)$, crowns $(85.5 \%)$, metal restorations $(68.9 \%)$, and 
Table 2 Frequencies of repairs of different restoration materials (amalgam, composite, ceramic, metal) as well as of crowns

\begin{tabular}{llllll}
\hline & \multicolumn{3}{l}{ Repair of } & & \\
\cline { 2 - 6 } & Amalgam $^{\mathrm{A}}$ & Composite $^{\mathrm{B}}$ & Ceramic $^{\mathrm{C}}$ & Metal $^{\mathrm{A}}$ & Crowns $^{\mathrm{C}}$ \\
\hline Frequent $(>50 \%)$ & $4.9 \%$ & $14.6 \%$ & $3.2 \%$ & $1.8 \%$ & $5.0 \%$ \\
Sometimes $(<50 \%)$ & $18.8 \%$ & $37.9 \%$ & $18.1 \%$ & $13.6 \%$ & $22.0 \%$ \\
Occasional $(<10 \%)$ & $37.8 \%$ & $40.9 \%$ & $64.5 \%$ & $53.6 \%$ & $58.8 \%$ \\
Sum $(\Sigma)$ & $61.4 \%$ & $93.4 \%$ & $85.8 \%$ & $68.9 \%$ & $85.8 \%$ \\
Never $(0 \%)$ & $38.6 \%$ & $6.6 \%$ & $14.2 \%$ & $31.1 \%$ & $14.2 \%$ \\
\hline
\end{tabular}

Repair frequencies were grouped into four categories: never $0 \%$, occasional $<10 \%$, sometimes $<50 \%$, and frequent $>50 \%$ of all failed restorations. The distribution of repair frequencies differed significantly $(p<0.001)$ among the restoration materials (except for amalgam vs. metal and ceramic vs. crowns). Different superscript uppercase letters mark significant differences between the frequencies of repair. Due to the effect of rounding, some numbers do not sum up to $100 \%$ amalgam restorations (61.4\%). However, the distribution of repair frequencies differed significantly among the restoration materials (Table 2). For some restorative materials, age, gender, practice location, practice setting, or specialization/field of activity showed a significant effect on the repair frequency (Table 3).

\section{Reasons for decision to repair}

The reasons for repair were extending the longevity of restorations $(81.4 \%)$, preservation of tooth substance $(65.8 \%)$, reduction of patients' costs compared to replacement $(58.4 \%)$, temporary restoration $(49.8 \%)$, patients' request $(47.9 \%)$, reduction of treatment time compared to replacement $(34.3 \%)$, and restoration within warranty period $(6.2 \%)$.

\section{Decision making criteria}

The decision to perform repair restorations was made based on the following factors: size of defect $(91.1 \%$, maximum size suitable for repair was $24.3 \%( \pm 13.3 \%)$ of the defective restoration), kind of restorative material $(80.5 \%)$, size of defective restoration $(64.2 \%)$, localization of defect (e.g., palatal, proximal, $51.4 \%$ ), age of defective restoration (42.8\%), and kind of tooth $(22.4 \%)$. Repair was more often considered for molars $(90.9 \%)$ than for premolars $(79.7 \%)$ and anterior teeth $(54.5 \%)$. Interestingly, most of the dentists $(76.2 \%)$ declared to consider the repair of restorations independently on who performed the original restoration. Just $1.5 \%$ of the dentists considered none of the above-mentioned criteria to be relevant for their treatment decision.
Table 3 Influence of age, gender, practice location, practice setting, and specialization/field of activity on the repair frequency (never

$0 \%$, occasional $<10 \%$, sometimes $<50 \%$, and frequent $>50 \%$ ) for different restoration materials (amalgam, composite, ceramic, metal, crowns)

\begin{tabular}{|c|c|c|c|c|c|}
\hline & \multicolumn{5}{|l|}{ Repair of } \\
\hline & Amalgam & Composite & Ceramic & Metal & Crowns \\
\hline Age & $<0.001 *$ & 0.502 & $<0.001 *$ & 0.968 & 0.676 \\
\hline $\begin{array}{l}\text { Gender } \\
\text { Female/male }\end{array}$ & 0.076 & 0.932 & 0.781 & $0.031 *$ & 0.117 \\
\hline $\begin{array}{l}\text { Practice location } \\
\text { Rural/towns/cities }\end{array}$ & $<0.001 *$ & 0.361 & 0.548 & 0.489 & $0.014 *$ \\
\hline $\begin{array}{l}\text { Practice setting } \\
\text { Single practitioner/multiple dentists/ } \\
\text { dental schools }\end{array}$ & $<0.001 *$ & 0.058 & 0.256 & 0.396 & 0.196 \\
\hline $\begin{array}{l}\text { Specialization/field of activity } \\
\text { Yes/no }\end{array}$ & $<0.001 *$ & $<0.001 *$ & 0.402 & 0.929 & $0.037 *$ \\
\hline
\end{tabular}

Significant effects are marked by an asterisk. Age: Amalgam restorations were repaired more frequently by older dentists $(\tau=0.08)$, while ceramic restorations were more frequently repaired by younger dentists $(\tau=-0.09)$. Gender: Metal restorations were more frequently repaired by male than by female dentists. Practice location: Amalgam restorations and crowns were more frequently repaired in rural areas than in other practice locations. Practice setting: Amalgam restorations were more frequently repaired by single practitioners than by dentists in other practice settings. Specialization/field of activity: Amalgam and composite restorations as well as crowns were more frequently repaired by dentists without any specialization 
Table 4 Restoration failures suitable for repair restorations

\begin{tabular}{lllll}
\hline & \multicolumn{2}{l}{ Repair of } & & \\
\cline { 2 - 5 } & Amalgam & Composite & Ceramic & Metal \\
\hline Partial loss of restorations & $82.7 \%$ & $80.8 \%$ & $63.9 \%$ & $27.5 \%$ \\
Loss of adjacent hard tissue & $69.2 \%$ & $72.4 \%$ & $49.4 \%$ & $48.8 \%$ \\
Secondary caries & $42.5 \%$ & $45.5 \%$ & $32.9 \%$ & $44.9 \%$ \\
Correction of anatomic form or color & $5.3 \%$ & $38.5 \%$ & $6.2 \%$ & $2.5 \%$ \\
Marginal gap & $39.8 \%$ & $53.5 \%$ & $35.4 \%$ & $39.8 \%$ \\
Marginal discoloration & $10.2 \%$ & $46.3 \%$ & $16.9 \%$ & $10.6 \%$ \\
Veneer chipping of crowns & - & - & $73.1 \%$ & $62.7 \%$ \\
Endodontic access cavity of crowns & - & - & $92.4 \%$ & $90.7 \%$ \\
\hline
\end{tabular}

Multiple selections were possible

\section{Restoration failures suitable for repair restorations}

The most frequent indications for repairs were the partial loss of restoration (28-83\%), loss of adjacent hard tissue (49$69 \%$ ), veneer chipping of crowns (63-73\%), and crowns with endodontic access cavities (91-92\%). Restorations with secondary caries were repaired by only $33-46 \%$ of the dentists. Further suitable failures were marginal gaps (35-54 \%), marginal discolorations (10-46\%) as well as corrections in form and color (3-39\%, Table 4).

\section{Techniques and materials involved in performing repairs}

Repair restorations were most frequently performed using composite (Table 5). Various techniques and materials for surface preconditioning were used. Only a minority (amalgam $4.2 \%$, composite $0.4 \%$, ceramic $0.6 \%$, and metal $3.4 \%$ ) did not perform any surface preconditioning or cleaning (Table 6).

\section{Patient acceptance of repair restoration and dentists' evaluation of longevity of repair restorations}

Most often, the participants stated that patients asked for repair instead of replacement of defective restorations even if its longevity is expected to be shorter compared to a new restoration $(61.5 \%)$. Thirty-one percent of patients were reported

Table 5 Frequencies of different dental materials used for repair

\begin{tabular}{lllll}
\hline Repair material & \multicolumn{2}{l}{ Repair of } & & \\
\cline { 2 - 5 } & Amalgam & Composite & Ceramic & Metal \\
\hline Amalgam & $46.2 \%$ & $1.0 \%$ & $0.5 \%$ & $7.5 \%$ \\
Composite & $72.3 \%$ & $99.8 \%$ & $97.8 \%$ & $95.6 \%$ \\
Cement & $16.0 \%$ & $4.7 \%$ & $3.8 \%$ & $15.3 \%$ \\
Other & $0.8 \%$ & $0.5 \%$ & $3.2 \%$ & $2.6 \%$ \\
\hline
\end{tabular}

Multiple selections were possible to agree with a repair restoration only when the longevity of the repair was expected to be similar to a replacement restoration. Just $7.1 \%$ of the patients were reported to refuse from repair restorations.

Most dentists ( $75.1 \%)$ considered the longevity as moderate, meaning that a repair restoration is suitable as permanent restoration, but the longevity is expected to be shorter than a replacement restoration. Only $9.7 \%$ of the dentists considered repair restorations as temporary restorations only, while $15.2 \%$ estimated repair restorations as highly successful with the longevity being comparable to a replacement restoration.

However, the assessment of repair restorations was significantly better with increasing frequency of performing repair restorations (Table 7). Moreover, the use of particular repair techniques was significantly correlated with the evaluation of repair restorations (Table 6).

\section{Discussion}

The current survey was conducted to investigate attitudes, practice, and experience regarding repair restorations among a representative cohort of German dentists (dentists from Lower Saxony).

The demographic data obtained from the questionnaires (mean age 49.3 years, males $59.6 \%$, females $40.4 \%$ ) well represented the member's statistic of the Lower Saxony dental chamber (mean age 48.6 years, males $60.9 \%$, females $39.1 \%$ ) and of all dentists in Germany (mean age 48.0 years, males $56.9 \%$, females $43.1 \%$ ) [12]. The response rate of the present study is comparable to other paper-based surveys in Germany, which yielded response rates between 9 and $21 \%$ [13-18]. However, as the anonymous design of the paper-based questionnaire did not allow for reminding non-responders, the potential for non-response bias cannot be excluded. Nonresponders might include a greater proportion of dentists not performing repair restorations and therefore being not interested in answering the questionnaire. To improve 
Table 6 Techniques and materials used for preconditioning of the repair surface in percent

\begin{tabular}{|c|c|c|c|c|}
\hline & \multicolumn{4}{|l|}{ Repair of } \\
\hline & Amalgam & Composite & Ceramic & Metal \\
\hline \multirow[t]{2}{*}{ Surface cleaning } & $69.7 \%$ & $69.9 \%$ & $71.0 \%$ & $66.9 \%$ \\
\hline & 0.360 & 0.181 & 0.285 & 0.615 \\
\hline \multirow{2}{*}{$\begin{array}{l}\text { Preparation of } \\
\text { macroretentions }\end{array}$} & $66.7 \%$ & $35.8 \%$ & $27.4 \%$ & $43.4 \%$ \\
\hline & 0.288 & 0.176 & 0.106 & 0.367 \\
\hline \multirow[t]{2}{*}{ Surface roughening } & $46.5 \%$ & $75.5 \%$ & $70.1 \%$ & $55.0 \%$ \\
\hline & 0.748 & 0.539 & 0.870 & 0.202 \\
\hline \multirow{2}{*}{$\begin{array}{l}\text { Application of phosphoric } \\
\text { acid }\end{array}$} & $24.4 \%$ & $67.3 \%$ & $36.3 \%$ & $29.6 \%$ \\
\hline & 0.914 & $\begin{array}{l}0.007 * \\
\quad(\text { OR } 1.42)\end{array}$ & 0.481 & 0.245 \\
\hline $\begin{array}{l}\text { Application of hydrofluoric } \\
\text { acid }\end{array}$ & - & - & $\begin{array}{l}43 \% \\
0.543\end{array}$ & - \\
\hline \multirow[t]{2}{*}{ Sandblasting } & $4.3 \%$ & $15.1 \%$ & $28.9 \%$ & $22.7 \%$ \\
\hline & $\begin{array}{l}<0.001 * \\
\quad(\text { OR } 3.09)\end{array}$ & $\begin{array}{l}0.012 * \\
\quad(\text { OR } 1.50)\end{array}$ & $\begin{array}{l}0.008 * \\
\quad(\text { OR } 1.44)\end{array}$ & $\begin{array}{l}0.009^{*} \\
\quad(\text { OR } 1.52)\end{array}$ \\
\hline \multirow[t]{2}{*}{ Application of silane } & $5.4 \%$ & $17.5 \%$ & $60.7 \%$ & $29.4 \%$ \\
\hline & 0.100 & 0.215 & 0.345 & 0.733 \\
\hline \multirow[t]{2}{*}{ Application of adhesives } & $43.7 \%$ & $93.6 \%$ & $85.6 \%$ & $66.8 \%$ \\
\hline & 0.725 & 0.522 & 0.578 & 0.202 \\
\hline \multirow[t]{2}{*}{ Application of opaquer } & $1.2 \%$ & $7.5 \%$ & $28.0 \%$ & $23.3 \%$ \\
\hline & 0.121 & 0.998 & 0.990 & 0.349 \\
\hline \multirow[t]{2}{*}{ other } & $0.3 \%$ & $0.7 \%$ & $0.6 \%$ & $0.9 \%$ \\
\hline & 0.576 & 0.200 & 0.899 & 0.536 \\
\hline
\end{tabular}

Multiple selections were possible. Ordered logistic regressions evaluated the effect of different preconditioning techniques and materials on dentists' evaluation of repaired restorations. Significant $p$ values are marked by an asterisk. The assessment of repair restorations was significantly better when dentists stated to use phosphoric acid (for composite repair restorations) or sandblasting of the surface (for all restorative materials), see odds ratios measurement errors which occur when a respondent's answer is inaccurate or imprecise, validity and objectivity of the questionnaire were controlled in advance. Moreover, a recent study has shown that there is a high concordance between questionnaire responses and actual treatment to repair or replace defective restorations [19].

The most important result of this study is that only a small proportion of responders stated to never perform repair restorations and/or to consider repair restorations just as a temporary restoration. The vast majority implemented repair restorations in daily practice, while defective composite restorations were repaired most often. The more often repairs were performed; the better was the estimated success of repair restorations.

Restorative treatment decisions were shown to be correlated to various dentist- and patient-related variables, such as age, gender, and experience of the dentist or caries risk and age of the patient [20-23]. However, the present survey found just some associations between the frequency to perform repair restorations and dentist-related variables but no clear pattern or "type of dentist" performing repair restorations on a frequent basis. Nevertheless, it can be assumed that dentists

Table 7 Ordered logistic regressions revealed significant effects of different repair frequencies on dentists' evaluation of repaired restorations (low and mediate vs. high, low vs. mediate and high)

\begin{tabular}{|c|c|c|c|c|c|}
\hline & \multicolumn{5}{|l|}{ Repair of } \\
\hline & Amalgam & Composite & Ceramic & Metal & Crowns \\
\hline $\mathrm{p}$ & $<0.001$ & $<0.001$ & $<0.001$ & $<0.001$ & $<0.001$ \\
\hline OR [95 \% CI] & $1.86[1.63,2.12]$ & $1.96[1.70,2.26]$ & $1.44[1.22,1.70]$ & $1.49[1.28,1.75]$ & $1.45[1.24,1.69]$ \\
\hline
\end{tabular}

Odds ratios with $95 \%$ confidence intervals $[\mathrm{CI}]$ are shown. Increasing the frequency of performing repair restorations will increase the assessment of repair restorations as being successful by the factor of the odds ratio. Low: Repair restorations are considered as temporary restorations only. Mediate: Longevity is expected to be shorter than a replacement restoration. High: Longevity is comparable to a replacement restoration 
performing repair restorations are generally less invasive in their restorative treatment decisions [24].

The treatment decision might be also dependent on different tooth- or restoration-related factors, such as age and size of restoration, kind of affected restorative material, and kind of affected tooth [25]. This was also shown in the present survey, where the decision making was mainly related to the size of the defect and of the restoration and to the kind of defective restorative material. Interestingly, most of the dentists of the present survey made their clinical decision independent of who was doing the original restoration. In a previous study, it was shown that repair was more likely if the same dentist had placed the restoration than if another operator had performed the original restoration [25].

Conditions suitable for repair were mainly functional failures of the original restoration (e.g., partial loss of restoration, loss of adjacent hard tissue, marginal gaps, and endodontic access cavities or veneer chipping of crowns) rather than biological (secondary caries) or esthetic (marginal discoloration, correction of color) reasons. It is supposed that the diagnosis of secondary caries is often expected to be associated with general undermining caries that is not accessible for repair. In contrast to the present study, secondary caries was significantly more likely to be repaired by US dentists than restorations with fractures or bulk fractures [22]. One possible explanation for this observation is the fact that most studies reported secondary caries to be the main reason for failure of the original restoration. However, it has also taken into consideration that diagnosing a defective restoration is quite challenging [2], especially in case of secondary caries [26].

Repair restorations were mostly done with composite, but huge differences existed with regard to the techniques and materials used for preconditioning of the repair surface. Dentists using certain techniques (e.g., sandblasting) valued repair restorations more frequently as permanent restorations compared to dentists refraining from these techniques. Clinical studies evaluating the effect of different surface preconditioning techniques and materials on the survival of repair restorations are not available so far, but from in vitro studies, it is known that bond strength of composite repair restorations is generally increased by mechanical roughening or sandblasting of the surface and by the application of a silane solution and a bonding system [2]. It can be speculated that dentists following this scheme observed an adequate survival of repair restorations leading to a better evaluation of repairs compared to dentists refraining from surface conditioning. Due to small number of dentists refraining from any surface conditioning, a statistical analysis of this assumption was not possible.

Most dentists expected the longevity of repair restorations to be shorter than the longevity of a replacement restoration. This estimation is in good accordance to a recent study from the Netherlands, which found the annual failure rate of repaired composite and amalgam restorations to be 5.7 and
$9.3 \%$ after 4 years [27] and, thus, to be higher when compared to "new" composite and amalgam fillings [28].

In conclusion, repair restorations were frequently performed and were well accepted by patients and dentists, but indications for repair restorations as well as applied materials and techniques varied distinctly.

Acknowledgments The authors want to thank the Zahnärztekammer Niedersachsen for their support and cooperation and all participating dentists for their contributions.

\section{Compliance with ethical standards}

Funding This study was funded by Zahnärztekammer Niedersachsen by mailing the questionnaire together with personalized cover letters and stamped return envelopes to all registered dentists in Lower Saxony.

Conflict of interest The authors declare that they have no conflict of interest.

Ethical approval All procedures performed in studies involving human participants were in accordance with the ethical standards of the institutional and/or national research committee and with the 1964 Helsinki Declaration and its later amendments or comparable ethical standards. The study was approved by the local ethics committee (no. 18/11/14).

Informed consent Informed consent was obtained from all individual participants included in the study.

\section{References}

1. Jingarwar MM, Bajwa NK, Pathak A (2014) Minimal intervention dentistry - a new frontier in clinical dentistry. J Clin Diagn Res 8(7):ZE04-ZE08. doi:10.7860/JCDR/2014/9128.4583

2. Hickel R, Brushaver K, Ilie N (2013) Repair of restorations criteria for decision making and clinical recommendations. Dent Mater 29(1):28-50. doi:10.1016/j.dental.2012.07.006

3. Blum IR, Lynch CD, Schriever A, Heidemann D, Wilson NH (2011) Repair versus replacement of defective composite restorations in dental schools in Germany. Eur J Prosthodont Restor Dent 19(2):56-61

4. Blum IR, Lynch CD, Wilson NH (2012) Teaching of direct composite restoration repair in undergraduate dental schools in the United Kingdom and Ireland. Eur J Dent Educ 16(1):e53-e58. doi:10.1111/j.1600-0579.2010.00674.x

5. Blum IR, Lynch CD, Wilson NH (2012) Teaching of the repair of defective composite restorations in Scandinavian dental schools. J Oral Rehabil 39(3):210-216. doi:10.1111/j.1365-2842.2011.02260.x

6. Lynch CD, Hayashi M, Seow LL, Blum IR, Wilson NH (2013) The management of defective resin composite restorations: current trends in dental school teaching in Japan. Oper Dent 38(5):497504. doi:10.2341/12-217-C

7. Setcos JC, Khosravi R, Wilson NH, Shen C, Yang M, Mjör IA (2004) Repair or replacement of amalgam restorations: decisions at a USA and a UK dental school. Oper Dent 29(4):392-397

8. Lynch CD, Blum IR, Frazier KB, Haisch LD, Wilson NH (2012) Repair or replacement of defective direct resin-based composite 
restorations: contemporary teaching in U.S. and Canadian dental schools. J Am Dent Assoc 143(2):157-163

9. Gordan VV, Mjör IA, Blum IR, Wilson N (2003) Teaching students the repair of resin-based composite restorations: a survey of North American dental schools. J Am Dent Assoc 134(3):317-323

10. Blum IR, Mjör IA, Schriever A, Heidemann D, Wilson NH (2003) Defective direct composite restorations - replace or repair? A survey of teaching in Scandinavian dental schools. Swed Dent J 27(3): 99-104

11. Blum IR, Schriever A, Heidemann D, Mjör IA, Wilson NH (2002) Repair versus replacement of defective direct composite restorations in teaching programmes in United Kingdom and Irish Dental Schools. Eur J Prosthodont Restor Dent 10(4):151-155

12. German Dental Association (2013) Mitgliederstatistik der (Landes)Zahnärztekammern. http://www.bzaek.de/wir-ueber-uns/datenund-zahlen/mitgliederstatistik.html. Accessed 06 May 2015

13. Ommerborn MA, Kollmann C, Handschel J, Depprich RA, Lang H, Raab WH (2010) A survey on German dentists regarding the management of craniomandibular disorders. Clin Oral Investig 14(2):137-144. doi:10.1007/s00784-009-0282-4

14. Mitov G, Dorr M, Nothdurft FP, Draenert F, Pospiech PR (2015) Post-endodontic treatment of incisors and premolars among dental practitioners in Saarland: an interactive web-based survey. Clin Oral Investig 19(5):1029-1037. doi:10.1007/s00784-014-1326-y

15. Willershausen I, Wolf TG, Schmidtmann I, Berger C, Ehlers V, Willershausen B, Briseno B (2015) Survey of root canal irrigating solutions used in dental practices within Germany. Int Endod J 48(7):654-660. doi:10.1111/iej.12360

16. Hertrampf K, Wenz HJ, Koller M, Wiltfang J (2012) Comparing dentists' and the public's awareness about oral cancer in a community-based study in Northern Germany. J Craniomaxillofac Surg 40(1):28-32. doi:10.1016/j.jcms.2010.11.011

17. Muller MP, Hansel M, Stehr SN, Weber S, Koch T (2008) A statewide survey of medical emergency management in dental practices: incidence of emergencies and training experience. Emerg Med J 25(5):296-300. doi:10.1136/emj.2007.052936

18. Naumann M, Kiessling S, Seemann R (2006) Treatment concepts for restoration of endodontically treated teeth: a nationwide survey of dentists in Germany. J Prosthet Dent 96(5):332-338. doi:10. 1016/j.prosdent.2006.08.028

19. Heaven TJ, Gordan VV, Litaker MS, Fellows JL, Rindal DB, Gilbert GH (2015) Concordance between responses to questionnaire scenarios and actual treatment to repair or replace dental restorations in the National Dental PBRN. J Dent 43(11): 1379-1384. doi:10.1016/j.jdent.2015.05.005

20. Riley JL, Gordan VV, Rouisse KM, McClelland J, Gilbert GH (2011) Differences in male and female dentists' practice patterns regarding diagnosis and treatment of dental caries. J Am Dent Assoc 142(4):429-440, doi:10.14219/jada.archive.2011.0199

21. Kakudate N, Sumida F, Matsumoto Y, Manabe K, Yokoyama Y, Gilbert GH, Gordan VV (2012) Restorative treatment thresholds for proximal caries in dental PBRN. J Dent Res 91(12):1202-1208. doi:10.1177/0022034512464778

22. Gordan VV, Riley JL III, Geraldeli S, Rindal DB, Qvist V, Fellows JL, Kellum HP, Gilbert GH, The DPBRN Collaborative Group (2012) Repair or replacement of defective restorations by dentists in The Dental PBRN. J Am Dent Assoc 143(6):593-601

23. Vidnes-Kopperud S, Tveit AB, Gaarden T, Sandvik L, Espelid I (2009) Factors influencing dentists' choice of amalgam and toothcolored restorative materials for class II preparations in younger patients. Acta Odontol Scand 67(2):74-79. doi:10.1080/ 00016350802577800

24. Heaven TJ, Gordan VV, Litaker MS, Fellows JL, Brad Rindal D, Firestone AR, Gilbert GH, National Dental PCG (2013) Agreement among dentists' restorative treatment planning thresholds for primary occlusal caries, primary proximal caries, and existing restorations: findings from The National Dental Practice-Based Research Network. J Dent 41(8):718-725. doi:10.1016/j.jdent.2013.05.014

25. Gordan VV, Riley J 3rd, Geraldeli S, Williams OD, Spoto JC 3rd, Gilbert GH, National Dental PCG (2014) The decision to repair or replace a defective restoration is affected by who placed the original restoration: findings from the National Dental PBRN. J Dent 42(12):1528-1534. doi:10.1016/j.jdent.2014.09.005

26. Brouwer F, Askar H, Paris S, Schwendicke F (2015) Detecting secondary caries lesions: a systematic review and meta-analysis. J Dent Res 95(2):143-151. doi:10.1177/0022034515611041

27. Opdam NJ, Bronkhorst EM, Loomans BA, Huysmans MC (2012) Longevity of repaired restorations: a practice based study. J Dent 40(10):829-835. doi:10.1016/j.jdent.2012.06.007

28. Manhart J, Chen H, Hamm G, Hickel R (2004) Buonocore Memorial Lecture. Review of the clinical survival of direct and indirect restorations in posterior teeth of the permanent dentition. Oper Dent 29(5):481-508 


\title{
Retrospective analysis on the repair vs. replacement of composite restorations
}

\author{
Philipp Kanzow*, Annette Wiegand \\ Department of Preventive Dentistry, Periodontology and Cariology, University Medical Center Göttingen, Germany
}

\section{A R T I C L E I N F O}

\section{Keywords:}

Minimally invasive dentistry

Composite materials

Restoration repair

Restorative dentistry

Success

Survival

\begin{abstract}
A B S T R A C T
Objective. Our retrospective study aimed to assess the impact of repairs on the longevity of anterior and posterior direct composite restorations and to compare longevity of repaired and replacement restorations.

Methods. Patient records were retrospectively screened for anterior and/or posterior composite restorations with 2+ surfaces placed in permanent teeth between 2000 and 2015 . During follow-up, repaired and replaced restorations were assessed and mean annual failure rates (mAFR) calculated. Outcome was considered in three levels: Success (no further intervention), survival 1 (first repair = survival, second repair = failure) and survival 2 (more than one repair = survival, all surfaces repaired $=$ failure). Statistical analysis was performed using Kaplan-Meier statistics, log-rank tests, and multi-variate Cox-regression analyses with shared frailty $(\mathrm{p}<0.05)$.

Results. 8542 initial restorations placed in 3239 patients were included ( $4.7 \pm 4.4$ years followup, $2.5 \pm 0.7$ surfaces). Longevity of initial restorations was prolonged by repair(s) (after 10 years: success: $68.3 \%$, mAFR: $3.7 \%$; survival 1: 77.3\%, mAFR: $2.5 \%$; survival 2: $80.4 \%$, mAFR: $2.2 \% ; \mathrm{p}<0.001) .616$ repaired restorations ( $4.9 \pm 4.2$ years follow-up, $3.5 \pm 1.0$ surfaces) and 264 replacement restorations ( $5.6 \pm 4.1$ years follow-up, $3.0 \pm 0.8$ surfaces) were analyzed. Success of repaired restorations amounted to $43.4 \%$ after 10 years (mAFR: $8.0 \%$ ), further repair(s) prolonged survival (survival 1: 65.7\%, mAFR: 4.1\%; survival 2: $74.8 \%$, mAFR: $2.9 \%$; $\mathrm{p}<0.001$ ). Success of replacement restorations amounted to $48.6 \%$ after 10 years (mAFR: 7.0\%), repair(s) prolonged survival (survival 1: 67.4\%, mAFR: 3.9\%, $p=0.044$; survival 2: 74.1\%, mAFR: $3.0 \%, p=0.003$ ).

Significance. Repairs are suitable to increase the survival of restorations; repaired restorations last as long as replacements.
\end{abstract}

C 2019 The Academy of Dental Materials. Published by Elsevier Inc. All rights reserved.
1.

\section{Introduction}

Longevity of dental restorations is limited. As a consequence, dental restorations often require re-treatment. Besides rather invasive re-interventions resulting in total replacement of the restoration, composite materials allow for minimal inva- sive repair measures of partially defective restorations leaving large parts of the original restoration in place.

Repairs are less invasive and able to prolong toothretention in the long-term [1]. Indeed, large retrospective studies have shown that repairs prolong the longevity of partially defective restorations. Ten-year mean annual failure rates (mAFR) of composite restorations were reported to

\footnotetext{
* Corresponding author.

E-mail address: philipp.kanzow@med.uni-goettingen.de (P. Kanzow). https://doi.org/10.1016/j.dental.2019.11.001

0109-5641/@ 2019 The Academy of Dental Materials. Published by Elsevier Inc. All rights reserved.
} 
amount to $3.1 \%$ for anterior [2] and $4.1 \%$ for posterior restorations [3]. By performing repairs, MAFR were lowered to $2.6 \%$ and $2.9 \%$, respectively. Twelve-year mAFR of composite posterior restorations was reduced from $1.8 \%$ to $0.7 \%$, when repairs were performed [4].

However, for clinicians and patients facing with a partially defective restoration it might not only be relevant if repairs increase the longevity of the original restoration, but rather if the repaired restoration will last as long as a replacement restoration. Thus, information on the survival of both treatment options (repair vs. replacement) is highly interesting. So far, only one study assessed the longevity of repaired restorations (4-year mAFR: 5.7\%) [4], but compared longevity to "newly" placed (i.e. initial restorations) rather than truly replaced restorations. Longevity of repaired restorations was lower than of newly placed restorations [4].

Based on the existing retrospective studies, the impact of different repair treatment concepts (i.e. single repairs or consecutive repairs) on the longevity of partially defective restorations has not been assessed. Furthermore, repaired restorations have not been compared with truly replaced rather than "newly" placed restorations. In this context it is also of interest if the remaining part of the original restoration or the repair is at higher risk of failure.

Therefore, our retrospective study aimed at assessing the impact of repairs on the longevity of anterior and posterior direct composite restorations and to compare longevity of repaired restorations and replacement restorations. Additionally, potential patient and restoration related risk factors on restorations' longevity were evaluated.

The null hypotheses were that (1) repairs do not change the survival of restorations and (2) longevity of repaired and replaced restorations is not different.

\section{Methods}

\subsection{Study design and participants}

Data of this retrospective study was based on digital dental records of patients attending the Department of Preventive Dentistry, Periodontology and Cariology at the University Medical Center Göttingen. The study was approved by the local ethics committee of the University Medical Center Göttingen (no. 7/9/18).

Patients that received at least one anterior and/or posterior composite restoration (two or more surfaces) placed in permanent teeth except wisdom teeth between January 2000 and December 2015 were included in the analysis. Restorations were performed and assessed by various dentists or students under supervision from experienced dentists of the department. Patients were excluded in case of restorations with missing information (e.g. no information regarding restored tooth/surfaces available). No further requirements (e.g. yearly check-ups, posterior occlusion, certain cavity class types) were made. Due to the retrospective design, no information regarding caries risk and reasons for interventions were available.

\subsection{Data collection}

All data were retrieved based on treatment fee codes from patients' digital dental records (CompuGroup Medical, Koblenz, Germany) and transformed pseudonymized into an excel data file. Interventions were filtered and survival times (years) calculated using Microsoft Excel for Mac (version 16.20).

Date of the placement of the initial composite restoration, dates of interventions (further direct restorations, indirect restorations, endodontic treatment, and extraction), and date of patients' last check-up were extracted. Both individual (age; gender; removable dentures; insurance status) and tooth/treatment related variables (tooth-location; tooth-type; jaw; previous endodontic treatment; number of initial restorations' surfaces; surfaces treated with each intervention) were assessed.

Additionally, repaired restorations (and separately the repair itself and the remaining part of the original restoration) and replacement restorations were analyzed. In case of multiple-surface restorations having been repaired, only the first repair was followed-up, e.g., if an initial mesial-occlusaldistal (MOD) restoration was repaired by a mesial-lingual restoration, further interventions at other surfaces than those already included in the first repair (e.g. placement of a separate distal-lingual repair restoration of the initial restoration) were not separately analyzed. However, further interventions at the first repair were followed-up.

A minimum follow-up of 2 weeks was required. To exclude early post-operative complications and pre-endodontic or pre-prosthetic restorations, respectively, restorations with interventions after less than 4 weeks were excluded.

\subsection{Outcome}

Separately for initial restorations, repaired restorations (repair and remaining part of the original restoration), and replacement restorations, outcome was considered in three levels:

Success (repairs = failure): All restorations without any further intervention on the initial restoration until the date of censoring (last check-up or last appointment when a restoration affecting other surfaces of the same tooth was placed) were considered clinically acceptable. If at least one of the "original" surfaces was re-restored or if further interventions (i.e. indirect restoration, endodontic treatment, tooth extraction) were necessary, restorations were regarded as failed at the date of the intervention. In case of interventions at $\mathrm{MO}$ and OD restorations (either mesial-occlusal and distal-occlusal or mesial-incisal and distal-incisal, respectively) at different appointments, analysis of the original restoration was censored at the time of re-restoration, as a clear differentiation between two separate restorations or a combined restoration would not have been possible.

Survival 1 (first repair=survival, second repair =failure): Restorations having been repaired once were considered clinically acceptable. "Repairs" were defined as situations, when, at least, one "original" surface of the restoration was not affected by the intervention. A second repair or complete replacement of restoration was considered as failure.

Survival 2 (more than one repair=survival, all surfaces repaired = failure): Restorations having been repaired, even in 


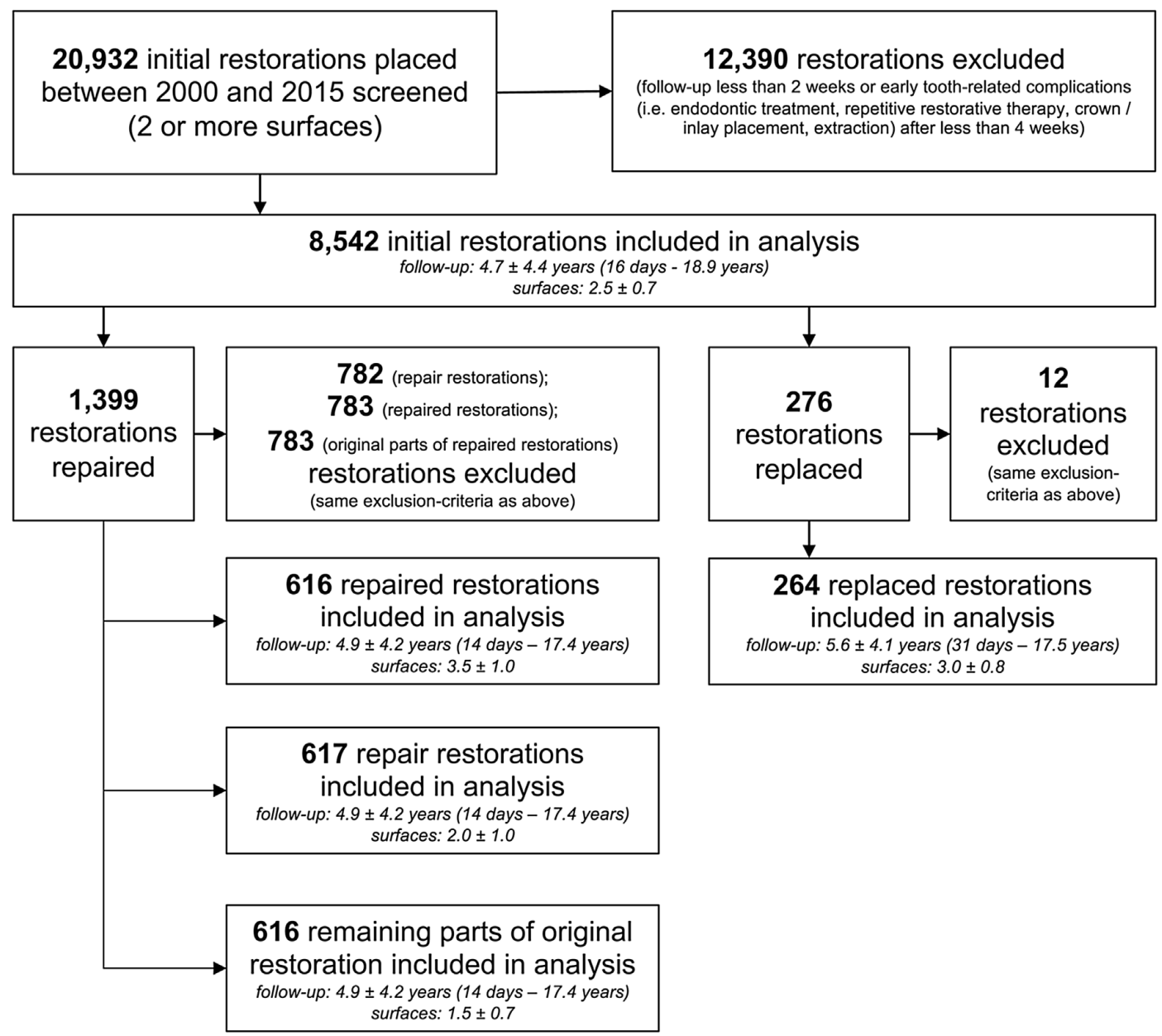

Fig. 1 - Flow chart of initial restorations, repaired restorations (separately for the repair and the remaining parts of the original restoration), and replacements included in the analysis. In $\mathbf{n}=1$ repaired restoration, a restorative intervention at the remaining part of the original restoration within 2 weeks after repair led to exclusion.

case of multiple repairs, were considered clinically acceptable. "Repairs" were defined as situations, when, at least, one "original" surface of the restoration was not affected by the intervention. When all "original" surfaces of the restoration were repaired, the restoration was considered as failed.

Within all levels, restorations were regarded as failed, if tooth-related interventions (i.e. indirect restoration placement, endodontic treatment, tooth extraction) were necessary. The date of the intervention was considered as the time point when the restoration had failed. Further restorations affecting other surfaces than those of the initial restoration or of the repair or replacement restorations, respectively, were ignored.

\subsection{Statistical analysis}

Statistical analysis was performed using the software R (version 3.6.1, www.r-project.org) and the packages "survminer" (version 0.4.5), "survival" (version 2.44-1.1) and "dplyr" (version 0.8.3). The level of significance was set at $\alpha=0.05$.
Longevity of restorations was assessed up to 15 years by Kaplan-Meier statistics. Mean annual failure rates were calculated at different time intervals $(2,5,10$, and 15 years, if available) by the following formula [5]:

$$
\begin{aligned}
(1-y)^{z}=1-x \\
y=1-\sqrt[z]{1-x} \\
y=\text { mean AFR; } x=\text { failure rate; } z \\
=\text { number of observation years }
\end{aligned}
$$

Log-rank tests were used to compare different outcome levels (success vs. survival 1, success vs. survival 2, survival 1 vs. survival 2) among initial restorations, repaired restorations, and replacement restorations. With regard to repaired restorations, log-rank tests were also used to compare different outcome levels within the repair itself and the remaining part of the original restoration. Success of repairs and of 
Table 1 - Characteristics of patients and restorations for initial, repaired, and replacement restorations.

\begin{tabular}{|c|c|c|c|c|}
\hline & & $\begin{array}{l}\text { Initial restorations } \\
\mathrm{N}(\%)\end{array}$ & $\begin{array}{l}\text { Repaired restorations } \\
\mathrm{N}(\%)\end{array}$ & $\begin{array}{l}\text { Replacement restorations } \\
\mathrm{N}(\%)\end{array}$ \\
\hline \multicolumn{2}{|l|}{$\mathrm{N}$} & $8542(100.0)$ & $616(100.0)$ & $264(100.0)$ \\
\hline \multicolumn{2}{|l|}{ Age $^{a}$} & $38.8 \pm 15.7$ & $44.1 \pm 17.1$ & $41.7 \pm 17.9$ \\
\hline \multicolumn{2}{|l|}{ Gender (male) } & $4360(51.0)$ & $312(50.6)$ & $130(49.2)$ \\
\hline \multicolumn{2}{|c|}{ Removable partial dentures (yes) } & $905(10.6)$ & $117(19.0)$ & $54(20.5)$ \\
\hline \multicolumn{2}{|c|}{ Insurance (private payer) } & $531(6.2)$ & $32(5.2)$ & $19(7.2)$ \\
\hline \multicolumn{2}{|l|}{ Jaw (lower) } & $2484(29.1)$ & $124(20.1)$ & $86(32.6)$ \\
\hline \multicolumn{2}{|l|}{ Side (left) } & $4178(48.9)$ & $315(51.1)$ & $144(54.5)$ \\
\hline & Incisor & $4435(51.9)$ & $465(75.5)$ & $160(60.6)$ \\
\hline \multirow[t]{2}{*}{ Tooth type } & Pre-molar & $2185(25.6)$ & $50(8.1)$ & $57(21.6)$ \\
\hline & Molar & $1922(22.5)$ & $101(16.4)$ & $47(17.8)$ \\
\hline \multicolumn{2}{|c|}{ Previous endodontic treatment (yes) } & $57(0.7)$ & $68(11.0)$ & $15(5.7)$ \\
\hline \multirow{5}{*}{$\begin{array}{l}\text { Number of surfaces of the } \\
\text { initial restoration }\end{array}$} & 2 & $5064(59.3)$ & $263(42.7)$ & $144(54.5)$ \\
\hline & 3 & $2431(28.5)$ & $238(38.6)$ & $87(33.0)$ \\
\hline & 4 & 959 (11.2) & $106(17.2)$ & 33 (12.5) \\
\hline & 5 & $70(0.8)$ & $9(1.5)$ & $0(0.0)$ \\
\hline & Unknown $^{b}$ & $18(0.2)$ & $0(0.0)$ & $0(0.0)$ \\
\hline
\end{tabular}

the remaining parts of the original restoration were also compared by log-rank test. Within each kind of restoration, log-rank tests were adjusted for multiple testing according to Bonferroni-Holm.

Separately for initial, repaired, and replacement restorations and success, survival 1, and survival 2, multi-variate Cox-regression models with shared frailty were used to identify hazard ratios (HR) and their respective 95\% confidence intervals (95\% CI) of factors associated with failure. Hence, shared frailty of correlated observations (restorations within the same patient) was taken into account.

Additionally, Cox-regression models with shared frailty (restorations within the same patient) were used to compare repaired and replaced restorations for success, survival 1, and survival 2. For this comparison, treatment (repair or replacement) was entered as additional variable.

\section{Results}

A total of 8542 initial restorations placed in 3239 patients were included in the analysis ( $4.7 \pm 4.4$ years follow-up, $2.5 \pm 0.7$ surfaces; Fig. 1). Characteristics of patients and restorations are shown in Table 1. Ten-year success rate of initial restorations amounted to $68.3 \%$ (mAFR: $3.7 \%$ ). Longevity of initial restorations was significantly prolonged by repair(s) (after 10 years: survival 1: $77.3 \%$, mAFR: $2.5 \%, p<0.001$; survival 2: $80.4 \%$, mAFR: $2.2 \%, p<0.001$; Fig. 2a). Multiple repairs prolonged survival compared to single repair (survival 1 vs. survival 2; $p=0.010$ ). Number of restorations at risk, survival probabilities and mAFR for further time points up to 15 years are shown in Table 2.

Among failed initial restorations, 616 repaired restorations ( $4.9 \pm 4.2$ years follow-up, $3.5 \pm 1.0$ surfaces) and 264 replacements ( $5.6 \pm 4.1$ years follow-up, $3.0 \pm 0.8$ surfaces) were assessed. Repaired restorations were separately assessed for repairs ( $\mathrm{n}=617,4.9 \pm 4.2$ years follow-up, $2.0 \pm 1.0$ surfaces) and the remaining part of the original restoration $(n=616$, $4.9 \pm 4.2$ years follow-up, $1.5 \pm 0.7$ surfaces). In $n=1$ repaired restoration, a restorative intervention at the remaining part of the original restoration within 2 weeks after repair led to exclusion from further analyzes.

Success rate of repaired restorations after 10 years amounted to $43.4 \%$ (10-year mAFR: $8.0 \%$ ). Longevity was prolonged by further repair(s) (after 10 years: survival 1: 65.7\%, mAFR: $4.1 \%, p<0.001$; survival 2: 74.8\%, mAFR: $2.9 \%, p<0.001$; Fig. 2b). Repetitive repairs prolonged survival compared to only one additional repair (survival 1 vs. survival 2; $p=0.045$ ).

With regard to the repaired restorations, success of the repair itself amounted to $46.3 \%$ (10-year mAFR: $7.0 \%$ ) after 10 years. Survival was prolonged by further repair(s) (after 10 years: survival 1: 61.7\%, mAFR: 3.9\%, p<0.001; survival 2: $63.5 \%$, mAFR: $3.0 \%, p<0.001$; Fig. 3a). Success rate of the remaining parts of the original restoration amounted to $58.8 \%$ (10-year mAFR: 5.2\%) after 10 years. Survival of this part of the repaired restoration was not prolonged by further repair(s) (after 10 years: survival 1: 63.4\%, mAFR: 4.5\%, $p=0.510$; survival 2: $64.1 \%$, mAFR: $4.4 \%, p=0.510$; Fig. $3 b)$. Among repaired restorations, success of remaining parts of the original restoration was higher than success of the repair ( $<<0.001$; Fig. 4).

Success of replacement restorations after 10 years amounted to $48.6 \%$ (10-year mAFR: 7.0\%). Longevity of replacement restorations was prolonged by repair(s) (after 10 years: survival 1: $67.4 \%$, mAFR: $3.9 \%, p=0.044$; survival 2: $74.1 \%$, mAFR: $3.0 \%, p=0.003$; Fig. 2c)

While repair(s) were suitable to prolong the survival of restorations (success vs. survival 1 and success vs. survival 2), there was no significant difference between longevity of repaired and replacement restorations within each level (success: $p=0.866$, survival $1: p=0.808$, survival 2 : $p=0.412$; Fig. 5).

Longevity of initial, repaired, and replacement restorations depended on various patient- and tooth-related variables 


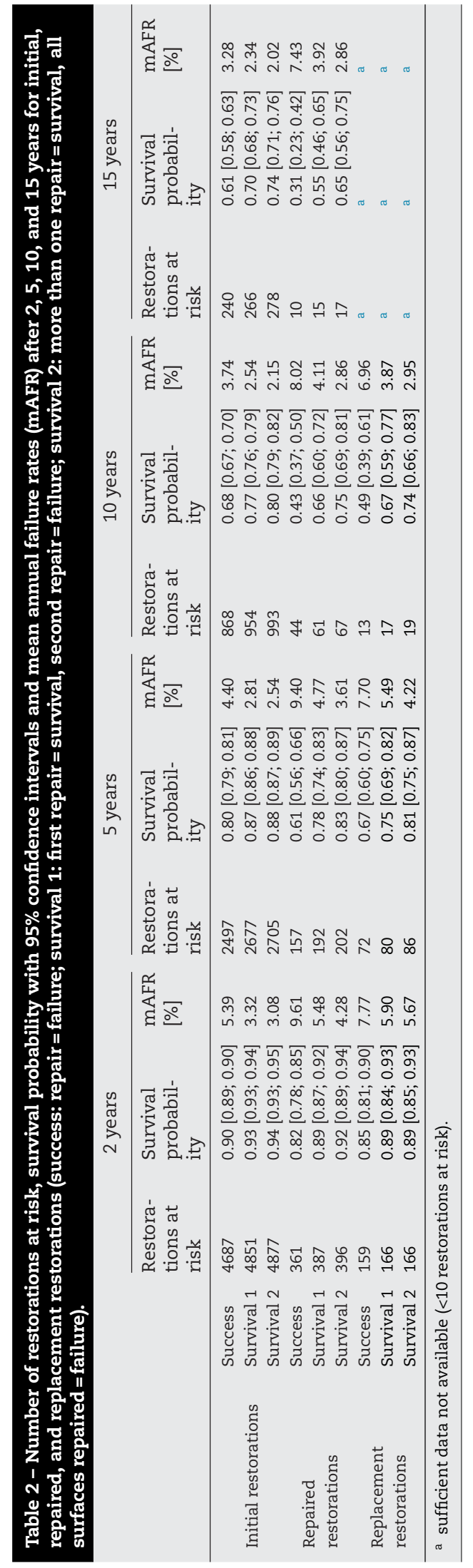




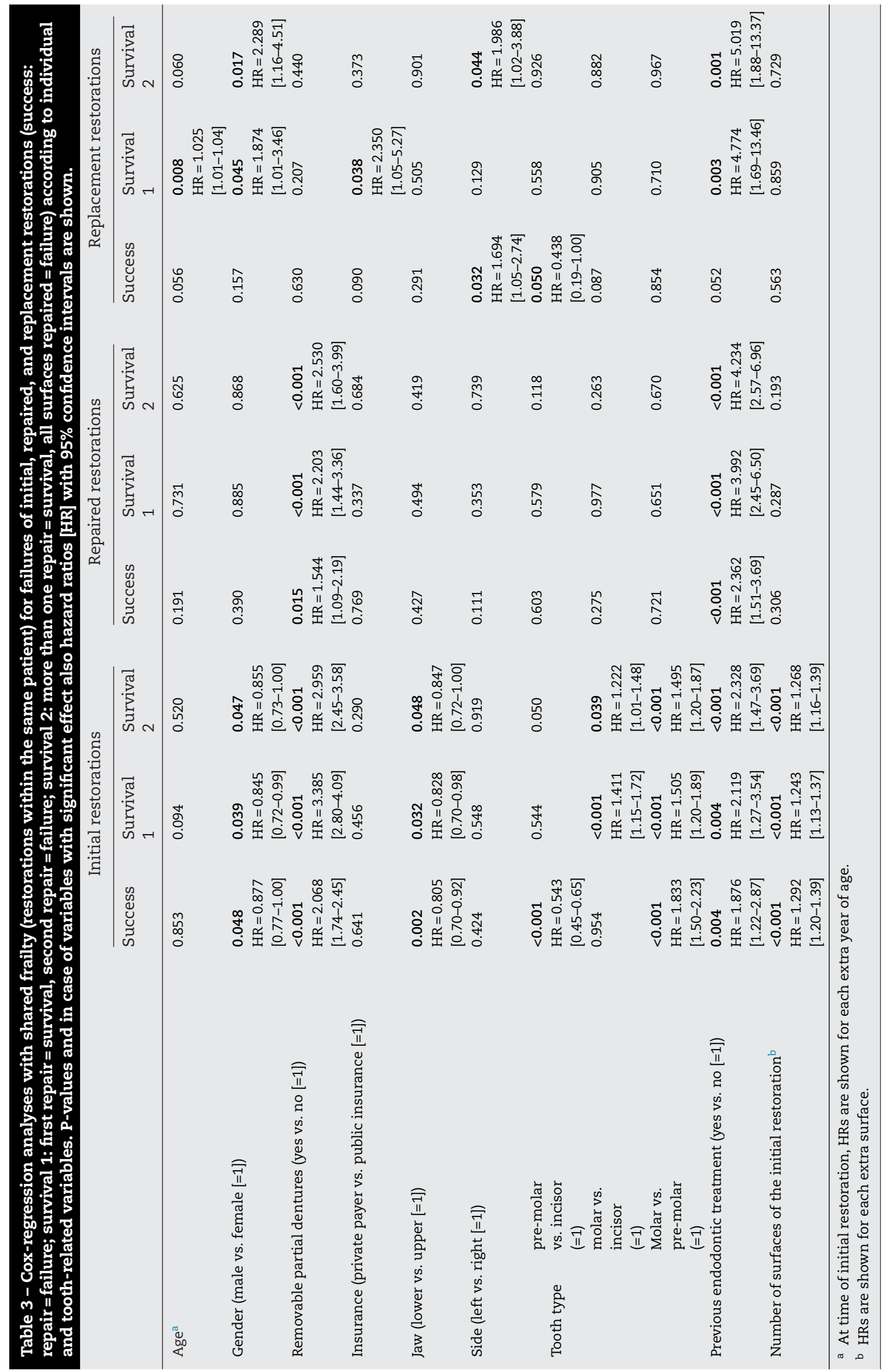




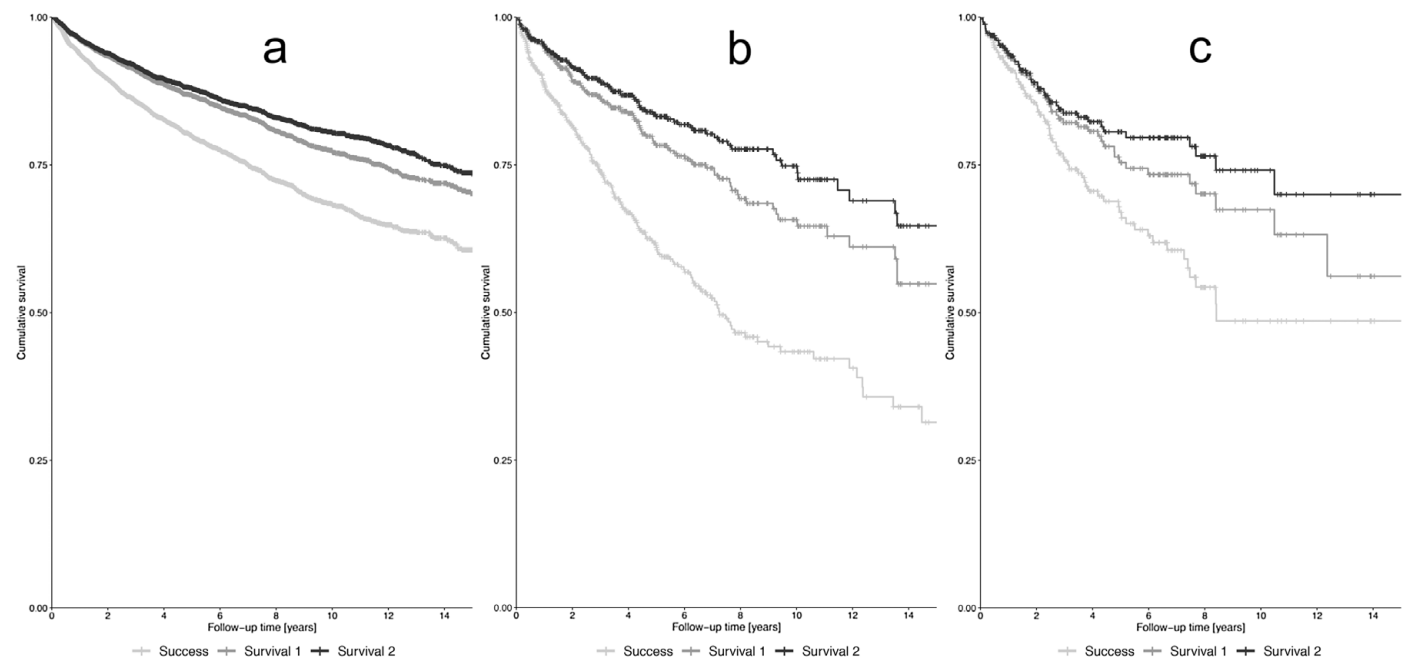

Fig. 2 - Kaplan-Meier survival graphs (over 15 years) of initial (a), repaired (b), and replacement (c) restorations. Success: repair $=$ failure; survival 1: first repair $=$ survival, second repair $=$ failure; survival 2: more than one repair $=$ survival, all surfaces repaired $=$ failure.
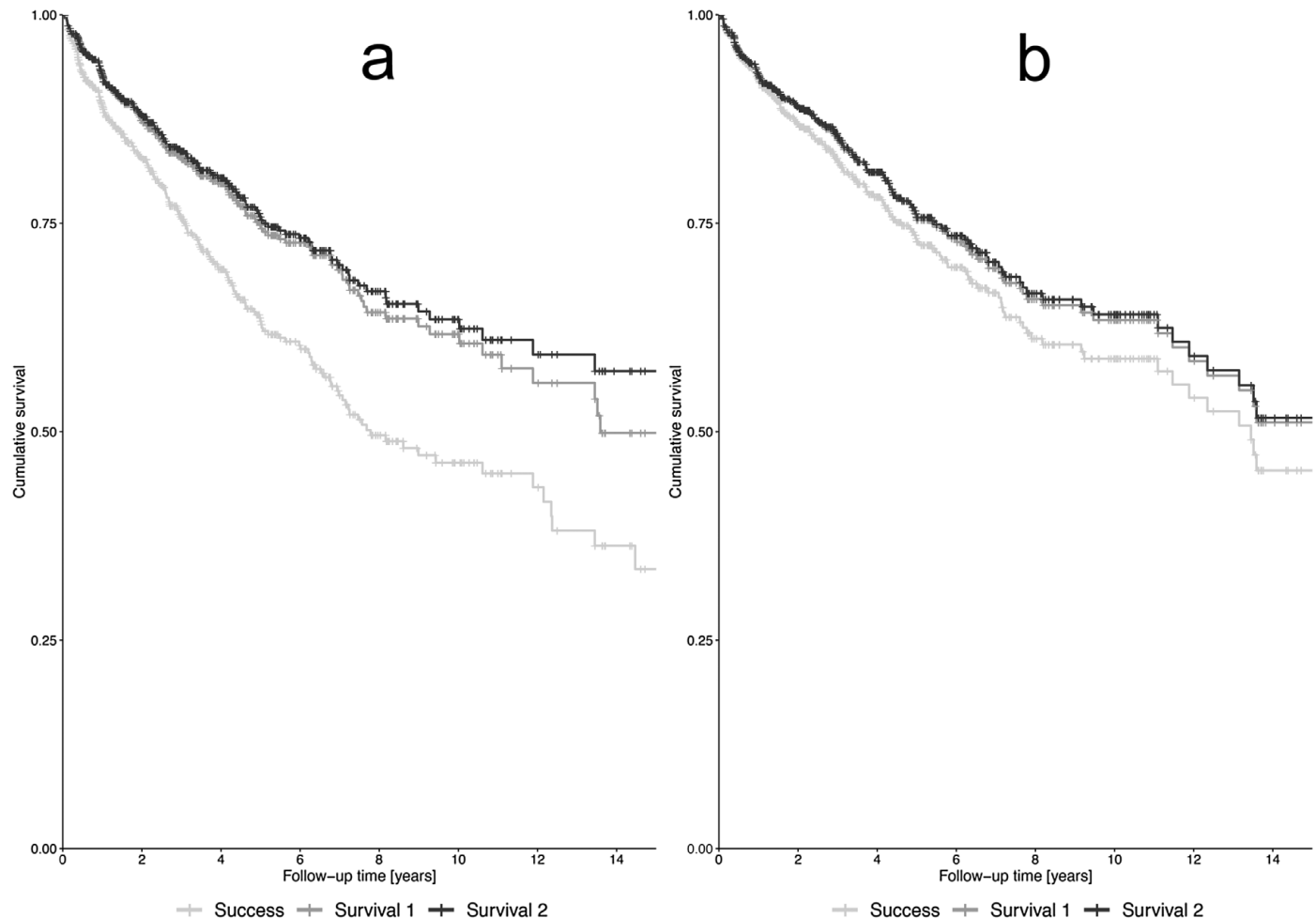

Fig. 3 - Kaplan-Meier survival graphs (over 15 years) of repairs (a) and remaining parts of the original restoration (b) for success, survival 1, and survival 2. Success: repair = failure; survival 1: first repair = survival, second repair = failure; survival 2: more than one repair $=$ survival, all surfaces repaired $=$ failure.

(Table 3). In almost all situations, previous endodontic treatment was an independent risk factor (HR: 1.9-5.0, $\mathrm{p} \leq 0.004$ ).

Based on these results, the first null hypothesis has to be rejected.

\section{Discussion}

While randomized controlled clinical studies (RCTs) regarding survival of repairs are still missing, clinical long-term per- 


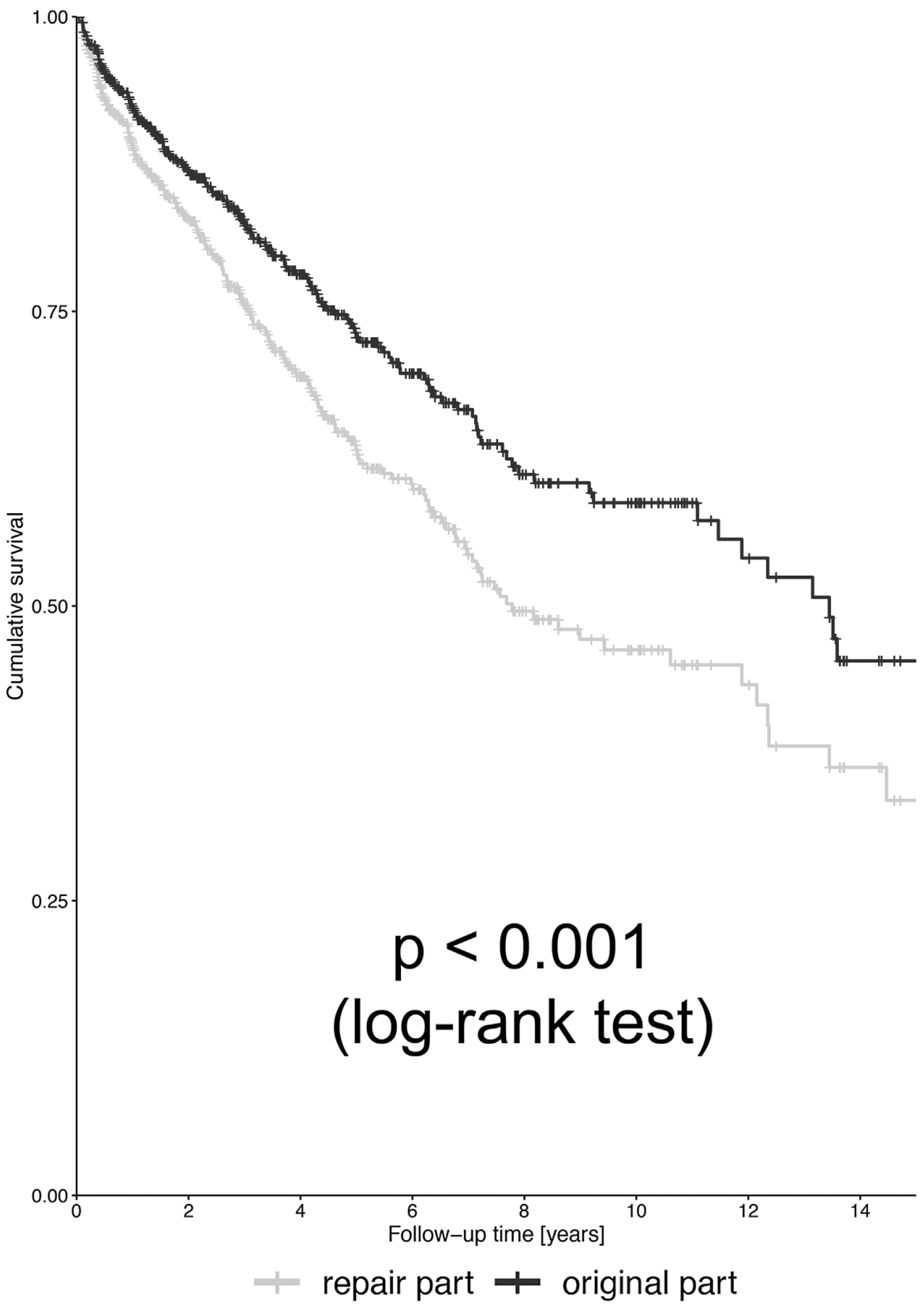

Fig. 4 - Kaplan-Meier survival graphs (over 15 years) comparing repairs and remaining parts of the original restoration for success.

formance of repairs has previously been assessed by several retrospective studies. These studies have shown that repair measures are suitable to prolong the survival of restorations [2-4,6]. However, different settings have been applied, and studies focused either on anterior or posterior restorations. Some analyses allowed even for multiple and subsequent repairs of the same restoration [2,3], while others considered multiple repairs as failure [4]. Even in children at high caries risk, repairs were able to increase survival of composite restorations in primary teeth [6].
In the clinical setting three situations and different "treatment concepts" are possible: Dentists who (1) never perform repairs and always replace partially defective restorations, (2) adopt repairs but allow for repairs only once, replacing partially defective restorations in case of subsequent failures, and (3) always repair partially defective restorations even multiple times in case of subsequent failures. To account for these "treatment concepts", we assessed longevity at different levels: Success (no further intervention), survival 1 (first 


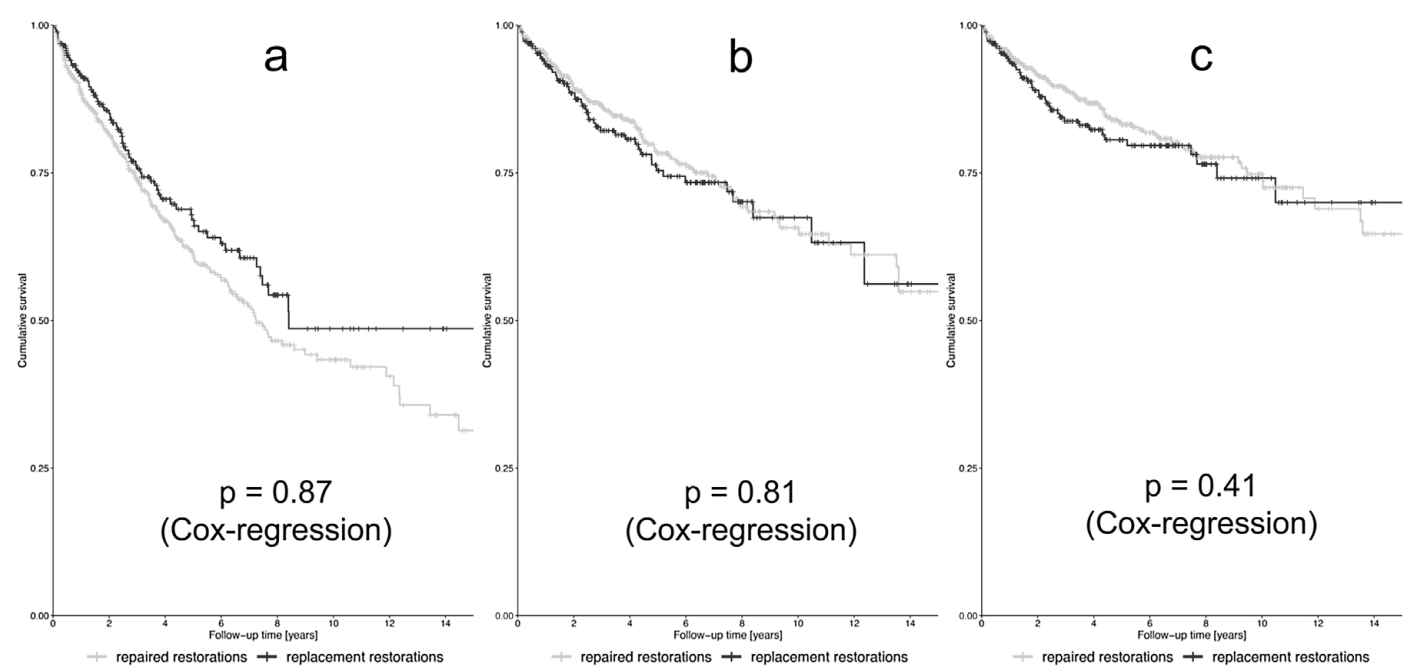

Fig. 5 - Kaplan-Meier survival graphs (over 15 years) of repaired restorations compared to replacement restorations for success (a), survival 1 (b), and survival 2 (c). Success: repair = failure; survival 1: first repair = survival, second repair = failure; survival 2: more than one repair = survival, all surfaces repaired = failure. $P$-values from Cox-regression analyses with shared frailty (restorations within the same patient).

repair $=$ survival, second repair $=$ failure) and survival 2 (more than one repair $=$ survival, all surfaces repaired $=$ failure).

Mean annual failure rates (mAFR) of composite restorations after 10 years amounted to $3.7 \%$ within success level (no intervention, no repairs). This result is in line with data from systematic reviews presenting mAFR of posterior composite restorations in permanent teeth between 0.6 and $4.2 \%$ [7-11]. For anterior composite class III and IV restorations, mAFR between 0.0 and $4.1 \%$ were reported [12,13]. Single repairs (survival 1) increased the survival of restorations and achieved a 10-year mAFR of $2.5 \%$. Repetitive repairs (survival 2), resulted in a 10 -year mAFR of $2.2 \%$, which is comparable to previous studies regarding the survival of repaired restorations (anterior restorations: 10 -year $\mathrm{mAFR} 2.6 \%$, posterior restorations: 10-year mAFR: $2.9 \%$ ) [2,3].

To the authors' best knowledge, this is the first study comparing clinical long-term performance of repaired restorations and truly replaced (rather than "newly" placed restorations). The present study shows that longevity of repaired restorations is comparable to those of replacement restorations. However, this finding has to be interpreted with caution as no information regarding the reason for failure/repair was available. Presence of further factors affecting longevity of replacements/repairs is unknown. For example, replacements might have been performed in more difficult situations or patients bearing certain risks (e.g. higher caries risk). The size of initial restoration might also influence longevity as dentists might tend to replace smaller restorations more often than performing a repair. However, this effect is probably limited as we included only initial restorations with at least two surfaces. Furthermore, size of the initial restoration was added as variable to the Cox-regression models but was assessed only indirectly based on the number of involved surfaces.

Among repaired restorations, the remaining parts of the original restoration showed a higher success rate than the repaired part. The lower success rate of repairs might be related to bonding failures: Bonding to an existing restoration might be still challenging, although a number of repair protocols have been published over the last decades [14].

To identify potential patient- and tooth-related risk factors impacting on the longevity of initial, repaired, and replacement restorations, multi-variate Cox-regression analyses were performed. As some patients received multiple restorations, data from the same patients were clustered to avoid bias resulting from shared frailty of correlated observations.

For initial restorations at all levels, female gender, removable partial dentures, location in the upper jaw, previous endodontic treatment of the respective tooth, larger restorations (i.e. higher number of surfaces), and restorations placed in molars were associated with a significantly higher risk of failure. This is mostly in line with previous studies [3,8,15-21]. However, conflicting results regarding the impact of the location (i.e. upper or lower jaw) were reported. While some studies report restorations in the upper jaw to be at a higher risk of failure [2,3], others describe higher risks for restorations in the mandibula [16], or report no effect of the location on restoration survival $[8,20,21]$.

For repaired restorations at all levels, both removable partial dentures and previous endodontic treatment of the respective tooth were associated with a higher risk of failure. As for failure of initial restorations, patients with removable partial dentures most likely experienced more caries and periodontal problems, and present higher chewing forces on the remaining teeth $[3,21]$. Therefore, restorations in these patients are exposed to a more challenging environment which negatively impacts on the survival time. Regarding the risk factors for replacement restorations, results differed from those for initial restorations and were more heterogeneous depending on the level being assessed. Except for replacement 
restorations at the success level, previous endodontic treatment was again related to a higher risk of failure. This is in line with previous studies showing that the longevity of direct restorations is reduced on endodontically treated compared to vital teeth $[3,6,9,17,18,21,22]$.

A number of limitations are being inherent to the character of the study design: Our retrospective study is based on data from treatment fee codes only. Therefore, "initial restorations" might have been already repaired or replacement restorations if initial treatments had been performed before. As patients might have visited other dentists in the meantime, the restorations might have been repaired or replaced without our knowledge. Furthermore, information regarding the caries risk and reasons for placement of initial restoration and subsequent repair or replacement treatments could not be evaluated. Also, repair techniques and specific products (e.g. adhesives/composites) could not be extracted from the fee codes. However, for direct restorations only adhesives in etch\&rinse-mode were used over the past decades, namely Syntac classic, Prime\&Bond NT, and Optibond FL. Due to the retrospective study design, no trial related patient visits were performed. Moreover, restorations were performed and assessed by various dentists or students under supervision from experienced dentists of the department.

Among the strength of the present study the large sample size must be noted. A total of 8542 restorations were included and followed up over their lifetime. Follow-up time amounted up to 18.9 years. While a large number of initial restorations was placed, as expected the number of repaired or replaced restorations was much lower. This large number of restorations compensates for the mentioned inaccuracies. As all procedures were performed at university standard, underlying data is likely to provide a rather accurate reflection of success and survival.

Based on our study it can be concluded that repairs are a suitable treatment to increase the survival of restorations, even after previous repairs or replacements. Furthermore, longevity of repair restorations is comparable to those of replacement restorations.

\section{Acknowledgements}

This research did not receive any specific grant from funding agencies in the public, commercial, or not-for-profit sectors. The authors would like to thank Silvia Meysing for assisting in the data extraction process. This study was previously presented at the 9 th CONSEURO, June $14^{\text {th }}-15^{\text {th }}, 2019$, Berlin, Germany.

\section{REFERENCES}

[1] Kanzow P, Wiegand A, Schwendicke F. Cost-effectiveness of repairing versus replacing composite or amalgam restorations. J Dent 2016;54:41-7, http://dx.doi.org/10.1016/j.jdent.2016.08.008.

[2] van de Sande FH, Moraes RR, Elias RV, Montagner AF, Rodolpho PA, Demarco FF, et al. Is composite repair suitable for anterior restorations? A long-term practice-based clinical study. Clin Oral Investig 2018;23:2795-803, http://dx.doi.org/10.1007/s00784-018-2722-5.

[3] Casagrande L, Laske M, Bronkhorst EM, M.C.D.N.J.M. Huysmans, Opdam NJM. Repair may increase survival of direct posterior restorations - a practice based study. J Dent 2017;64:30-6, http://dx.doi.org/10.1016/j.jdent.2017.06.002.

[4] Opdam NJ, Bronkhorst EM, Loomans BA, M.-C.D.N.J.M. Huysmans. Longevity of repaired restorations: a practice based study. J Dent 2012;40:829-35, http://dx.doi.org/10.1016/j.jdent.2012.06.007.

[5] Opdam NJ, Bronkhorst EM, Loomans BA, M.-C.D.N.J.M. Huysmans. 12-year survival of composite vs. amalgam restorations. J Dent Res 2010;89:1063-7, http://dx.doi.org/10.1177/0022034510376071.

[6] Ruiz LF, Nicoloso GF, Franzon R, Lenzi TL, de Araujo FB, Casagrande L. Repair increases the survival of failed primary teeth restorations in high-caries risk children: a university-based retrospective study. Clin Oral Investig 2019, http://dx.doi.org/10.1007/s00784-019-02899-9. E-pub ahead of print.

[7] Schwendicke F, Göstemeyer G, Blunck U, Paris S, Hsu LY, Tu YK. Directly placed restorative materials: review and network meta-analysis. J Dent Res 2016;95:613-22, http://dx.doi.org/10.1177/0022034516631285.

[8] Opdam NJM, van de Sande FH, Bronkhorst E, Cenci MS, Bottenberg P, Pallesen U, et al. Longevity of posterior composite restorations: a systematic review and meta-analysis. J Dent Res 2014;93:943-9, http://dx.doi.org/10.1177/0022034514544217.

[9] Demarco FF, Corrêa MB, Cenci MS, Moraes RR, Opdam NJ. Longevity of posterior composite restorations: not only a matter of materials. Dent Mater 2012;28:87-101, http://dx.doi.org/10.1016/j.dental.2011.09.003.

[10] Ástvaldsdóttir A, Dagerhamn J, van Dijken JW, Naimi-Akbar A, Sandborgh-Englund G, Tranæus S, et al. Longevity of posterior resin composite restorations in adults - a systematic review. J Dent 2015;43:934-54, http://dx.doi.org/10.1016/j.jdent.2015.05.001.

[11] Beck F, Lettner S, Graf A, Bitriol B, Dumitrescu N, Bauer P, et al. Survival of direct resin restorations in posterior teeth within a 19-year period (1996-2015): a meta-analysis of prospective studies. Dent Mater 2015;31:958-85, http://dx.doi.org/10.1016/j.dental.2015.05.004.

[12] Demarco FF, Collares K, Coelho-de-Souza FH, Correa MB, Cenci MS, Moraes RR, et al. Anterior composite restorations: a systematic review on long-term survival and reasons for failure. Dent Mater 2015;31:1214-24, http://dx.doi.org/10.1016/j.dental.2015.07.005

[13] Heintze SD, Rousson V, Hickel R. Clinical effectiveness of direct anterior restorations - a meta-analysis. Dent Mater 2015;31:481-95,

http://dx.doi.org/10.1016/j.dental.2015.01.015.

[14] Kanzow P, Wiegand A, Schwendicke F, Gostemeyer G. Same, same, but different? A systematic review of protocols for restoration repair. J Dent 2019;86:1-16, http://dx.doi.org/10.1016/j.jdent.2019.05.021.

[15] Opdam NJM, Bronkhorst EM, Roeters JM, Loomans BA. Longevity and reasons for failure of sandwich and total-etch posterior composite resin restorations. J Adhes Dent 2007;9:469-75, http://dx.doi.org/10.3290/j.jad.a12710.

[16] Pallesen U, van Dijken JWV, Halken J, Hallonsten AL, Höigaard R. Longevity of posterior resin composite restorations in permanent teeth in Public Dental Health Service: a prospective 8 years follow up. J Dent 2013;41:297-306, http://dx.doi.org/10.1016/j.jdent.2012.11.021.

[17] van de Sande FH, Opdam NJ, Rodolpho PA, Correa MB, Demarco FF, Cenci MS. Patient risk factors' influence on 
survival of posterior composites. J Dent Res 2013;92:78S-83S, http://dx.doi.org/10.1177/0022034513484337.

[18] Van Nieuwenhuysen JP, D'Hoore W, Carvalho J, Qvist V.

Long-term evaluation of extensive restorations in permanent teeth. J Dent 2003;31:395-405, http://dx.doi.org/10.1016/s0300-5712(03)00084-8.

[19] Pallesen U, van Dijken JWV. A randomized controlled 27 years follow up of three resin composites in class II restorations. J Dent 2015;43:1547-58, http://dx.doi.org/10.1016/j.jdent.2015.09.003.

[20] Laske M, Opdam NJM, Bronkhorst EM, Braspenning JCC, M.C.D.N.J.M. Huysmans. Risk factors for dental restoration survival: a practice-based study. J Dent Res 2019;98:414-22, http://dx.doi.org/10.1177/0022034519827566.

[21] Laske M, Opdam NJM, Bronkhorst EM, Braspenning JCC, M.C.D.N.J.M. Huysmans. Ten-year survival of class II restorations placed by general practitioners. JDR Clin Trans Res 2016;1:292-9,

http://dx.doi.org/10.1177/2380084416663192.

[22] Lucarotti PSK, Lessani M, Lumley PJ, Burke FJT. Influence of root canal fillings on longevity of direct and indirect restorations placed within the General Dental Services in England and Wales. Br Dent J 2014;216:e14, http://dx.doi.org/10.1038/sj.bdj.2014.244. 
Annette Wiegand, Prof. Dr. med. dent. and Philipp Kanzow, Dr. med. dent.

\section{Effect of Repairing Endodontic Access Cavities on Survival of Single Crowns and Retainer Restorations}

\section{SIGNIFICANCE}

Root canal treatment in crowned teeth (single crown or retainer restoration) usually requires the replacement of the restoration for a new one. This retrospective study shows that repairing endodontic access cavities with composite increases the longevity of single crowns and retainer restorations.
From the Department of Preventive Dentistry, Periodontology and Cariology, University Medical Center Göttingen, Göttingen, Germany

Address requests for reprints to $\mathrm{Dr}$ Annette Wiegand, Department of Preventive Dentistry, Periodontology and Cariology, University Medical Center Göttingen, Robert-Koch-Str. 40, 37075 Göttingen, Germany.

E-mail address: annette.wiegand@med. uni-goettingen.de 0099-2399/\$ - see front matter

Copyright @ 2019 American Association of Endodontists.

https://doi.org/10.1016/

j.joen.2019.11.012

\begin{abstract}
Introduction: This retrospective study aimed to analyze the effect of repairing endodontic access cavities with composite on the survival of single crowns and retainer restorations of fixed or removable dental prostheses. Methods: Dental records of patients attending a university dental clinic were retrospectively screened for single crowns and retainer restorations receiving endodontic treatment after crown placement. Survival (no further intervention) and failure (removal, loss or replacement of crown, replacement of access restoration, or recementation of restoration) of crowns and retainers with repaired endodontic access cavities were recorded. The mean annual failure rates were calculated, and the effect of individual-, tooth-, and restoration-related variables on survival was assessed by univariate log-rank tests and multivariate Cox regression analyses with shared frailty $(P<.05)$.

Results: One hundred eighty repaired crowns/retainers placed in 151 patients were included (4.5 \pm 3.3 years follow-up). Survival after 2, 5, 7, and 10 years amounted to $82.7 \%, 71.5 \%$, $67.3 \%$, and $48.8 \%$ (mean annual failure rate $=9.0 \%, 6.5 \%, 5.5 \%$, and $6.9 \%$ ), respectively. Although tooth type, kind of restoration, endodontic irrigant, repair conditioning methods, and kind of composite affected survival in the univariate regression analyses, only the kind of restoration (single crown vs retainer restoration) remained significant in the multivariate Cox regression model. Conclusions: Repairing endodontic access cavities with composite increases the longevity of single crowns and retainer restorations. (J Endod 2020;46:376-382.)
\end{abstract}

\section{KEY WORDS}

Composite; endodontic treatment; repair; retreatment; survival

Restoring endodontic access cavities of teeth with full-coverage restorations belongs to the most frequent indications for dental repair ${ }^{1,2}$. A relevant number of vital teeth require root canal treatment after crown preparation. A systematic review on the survival and complication rates of metal-ceramic and allceramic single crowns found the loss of tooth vitality to belong to the most frequent biological complications with an estimated incidence of $0.7 \%$ to $3.7 \%$ within 5 years ${ }^{3,4}$. Long-term survival of pulp vitality amounted to $85 \%$ (crowned teeth) and $71 \%$ (teeth as part of as fixed prostheses) after 10 years and $81 \%$ and $66 \%$, respectively, after 15 years ${ }^{5}$. Another study estimated the proportion of crowned teeth with vital pulp to $87 \%$ after 20 years and $83 \%$ after 25 years ${ }^{6}$. Not only primary endodontic treatment of crowned teeth but also retreatment often becomes necessary (eg, because of persistent interradicular infections) ${ }^{7}$.

Root canal treatment in crowned teeth usually requires the replacement of the restoration for a new one $^{8,9}$. Alternatively, the access cavity can be restored with composite provided that the original restoration is clinically satisfactory ${ }^{10}$. Restoration of endodontic access cavities with composite requires pretreatment of different substrates (metals, ceramics, and remaining tooth substance), which makes complex repair protocols necessary ${ }^{10,11}$. Moreover, bonding might further be affected by the contamination of dentin with endodontic materials, such as irrigants, temporary materials, or sealers ${ }^{10}$.

Although the fracture resistance and retention of crowns with (repaired) endodontic access cavities were frequently assessed in vitro, clinical data on the longevity of repaired crowns are scarce. One study on the survival of endodontically treated teeth reported that 33 of 42 crowns with repaired endodontic access cavities were successful during a mean observation period of 4.48 years ${ }^{12}$. 


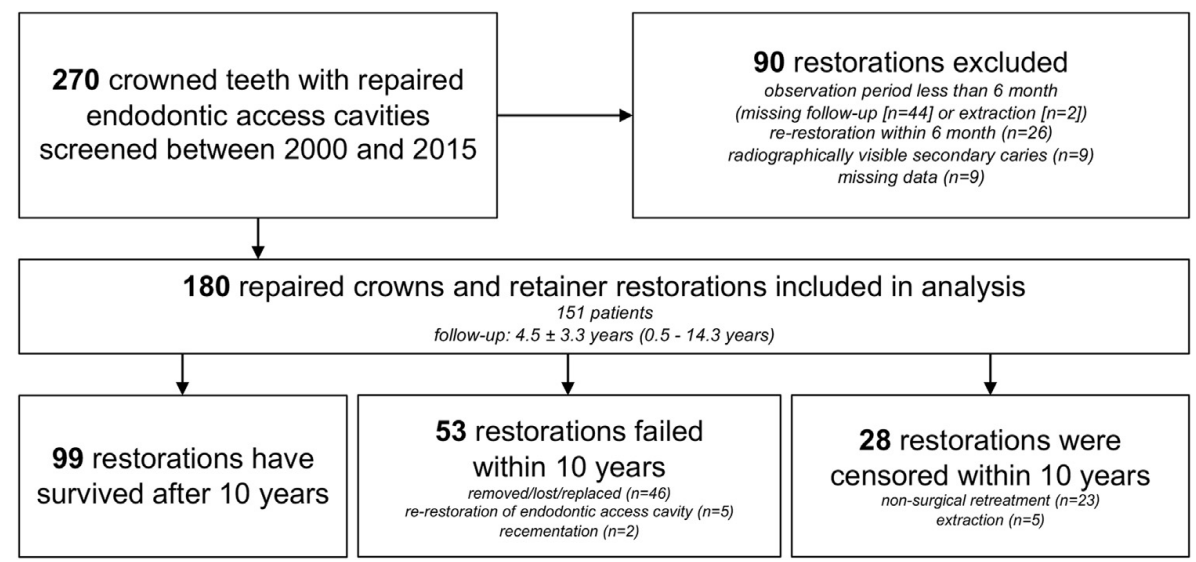

FIGURE 1 - A flowchart with excluded and included repaired single (partial) crowns and retainer restorations and repaired restorations that survived, failed, or were censored within 10 years.

TABLE 1 - Characteristics of the Patients and Involved Restorations and $P$ Values of the Univariate Analyses

\begin{tabular}{|c|c|c|c|}
\hline Patient age at repair (years, mean \pm SD) & \multicolumn{3}{|c|}{$\begin{array}{l}53.7 \pm 12.9(\text { minimum }=22.1 \\
\text { maximum }=78.4)\end{array}$} \\
\hline Age of restoration at repair (years, mean $\pm \mathrm{SD})^{\star}$ & \multicolumn{3}{|c|}{$\begin{array}{l}4.5 \pm 4.0(\text { minimum }=0.2 \\
\text { maximum }=15.5)\end{array}$} \\
\hline Follow-up time (years, mean $\pm \mathrm{SD}$ ) & \multicolumn{3}{|c|}{$\begin{array}{l}4.5 \pm 3.3(\text { minimum }=0.5 \\
\text { maximum }=14.3)\end{array}$} \\
\hline & $n$ & $\%$ & $P$ value \\
\hline Sex & & & NS \\
\hline Male & 90 & 50.0 & \\
\hline Female & 90 & 50.0 & \\
\hline Insurance & & & NS \\
\hline Public & 172 & 95.6 & \\
\hline Private payer & 8 & 4.4 & \\
\hline Location & & & NS \\
\hline Upper jaw & 96 & 53.3 & \\
\hline Lower jaw & 84 & 46.7 & \\
\hline Tooth type & & & .024 \\
\hline Anterior & 27 & 15.0 & \\
\hline Premolar & 58 & 32.2 & \\
\hline Molar & 95 & 52.8 & \\
\hline Restoration & & & $<.001$ \\
\hline Single (partial) crown & 111 & 61.7 & \\
\hline $\begin{array}{l}\text { Retainer restorations (telescopic crown or } \\
\text { fixed partial denture) }\end{array}$ & 69 & 38.3 & \\
\hline Material & & & NS \\
\hline Full metal & 76 & 42.2 & \\
\hline Porcelain fused to metal & 100 & 55.6 & \\
\hline Ceramic & 4 & 2.2 & \\
\hline Endodontic treatment & & & NS \\
\hline Primary endodontic treatment & 137 & 76.1 & \\
\hline Nonsurgical endodontic retreatment & 43 & 23.9 & \\
\hline Repair surface conditioning measures & & & \\
\hline Silica coating & 29 & 16.1 & .013 \\
\hline Silane/universal primer & 21 & 11.7 & .047 \\
\hline Adhesive $(n=105)^{\dagger}$ & & & NS \\
\hline Self-etch & 12 & 11.4 & \\
\hline Etch and rinse & 93 & 88.6 & \\
\hline Repair composite $(n=151)^{\dagger}$ & & & .049 \\
\hline Light curing & 128 & 84.8 & \\
\hline
\end{tabular}

NS, not significant $(P>.05)$; SD, standard deviation.

*The age of the restoration was known in only 84 cases; in 96 cases, restorations were placed outside the clinic.

${ }^{\dagger}$ For the remaining restorations, no information was available.
Because studies addressing the survival of repaired crowns in a clinical setting are highly required ${ }^{13}$, this retrospective study aimed to assess the effect of repairing endodontic access cavities with composite on the survival of full-coverage restorations and to identify potential variables affecting survival.

\section{MATERIALS AND METHODS}

\section{Study Design}

Data were extracted from digital and paperbased dental records of patients receiving primary endodontic treatment or nonsurgical retreatment at the Department of Preventive Dentistry, Periodontology and Cariology, University Medical Center Göttingen, Göttingen, Germany.

Patients who received composite repairs of the endodontic access cavities of single (partial) crowns or retainer restorations of fixed (fixed partial dentures) or removable partial dentures (telescopic crowns) between January 2000 and December 2015 were included. No further requirements (eg, yearly checkups) were made.

The study was approved by the local ethics committee of the University Medical Center Göttingen (no. 17/10/18).

\section{Data Collection}

Initially, data were retrieved based on treatment fee codes from patients' digital dental records (highdent plus, Version 5.65; CompuGroup Medical, Koblenz, Germany). Cases were filtered for primary endodontic treatment and for nonsurgical retreatment of crowned teeth. In a second step, paper-based treatment documentations and radiographs were assessed. All data were transformed 


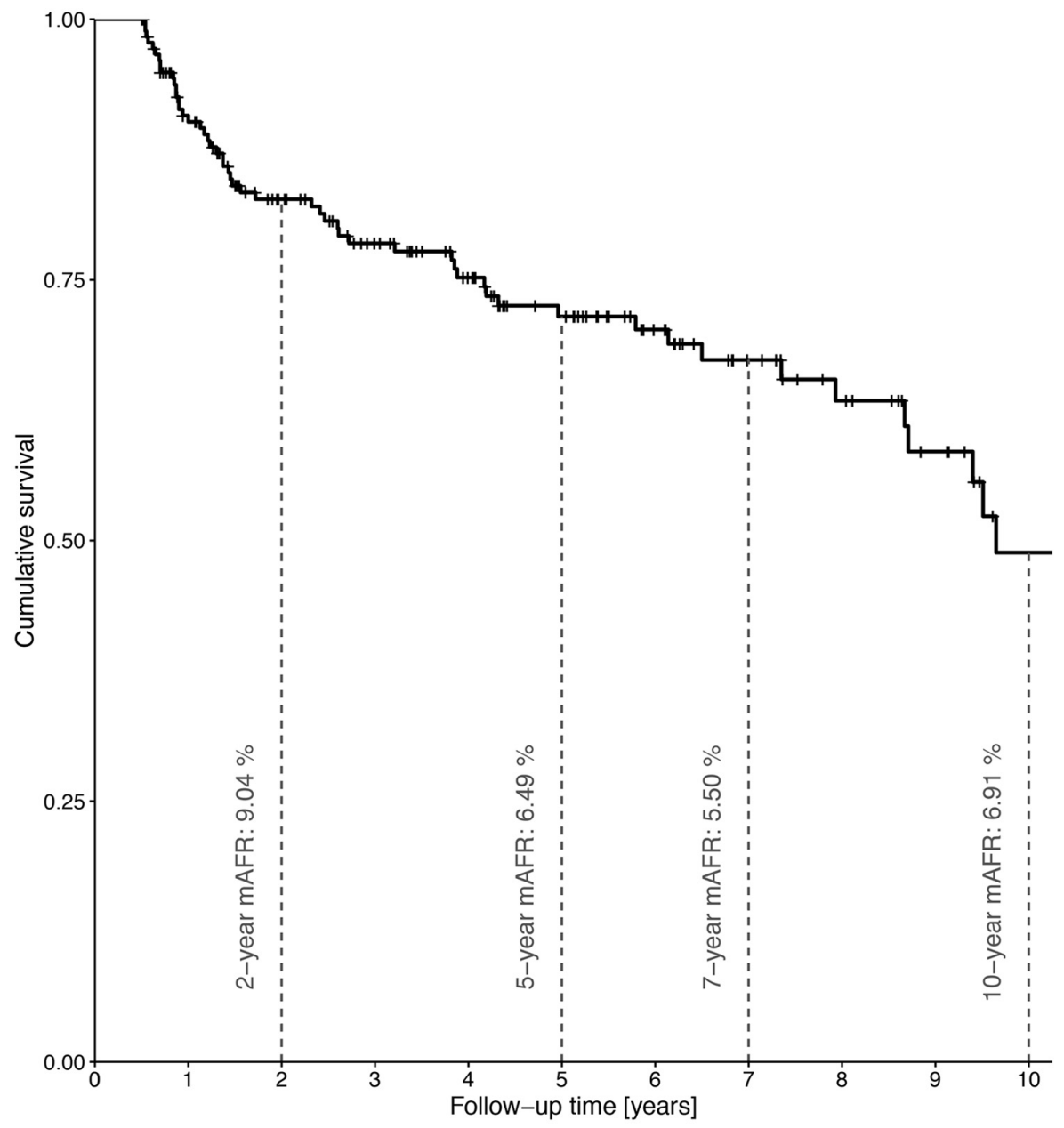

Restorations at risk:

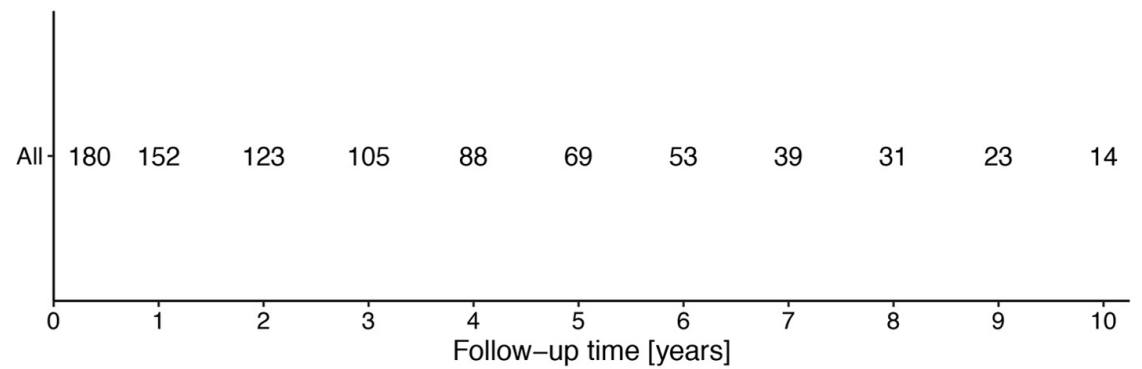

FIGURE 2 - The Kaplan-Meier survival graph (over 10 years) of repaired restorations. The number of repaired restorations at risk and the mAFRs after 2, 5, 7, and 10 years are presented. The removal, replacement, loss, or recementation of the repaired crown or retainer restoration or replacement of the access restoration were defined as events of interest. Censoring was performed when the intervention was not related to failure of the repaired restoration (eg, nonsurgical retreatment or tooth extraction).

pseudonymized into an Excel (Microsoft, Redmond, WA) data file. The survival (years) of repairs was calculated using Microsoft Excel for Mac (Version 16.26).

The date of the placement of the crown or retainer restoration (if available), the date of endodontic access cavity preparation, the dates of further interventions (eg, nonsurgical retreatment; tooth extraction; replacement of access restoration; and loss, removal, replacement, or recementation of restoration), and the date of the last clinical or radiologic checkup with the repaired crown in situ were extracted. Both individual- (sex and insurance status) and tooth- or restoration-related variables (tooth location [upper/lower jaw], tooth type [anterior/premolar/molar], kind of restoration [single (partial) crown/retainer of fixed partial denture], material of restoration [full metal/porcelain fused to metal/ceramic], endodontic treatment [primary treatment/ nonsurgical retreatment], kind of composite material [light curing/dual curing], kind of adhesive [self-etch/etch and rinse], and applied repair surface conditioning measures [silane or universal primer/silica coating]) were assessed. 
A minimum follow-up of 6 months was required; thus, restorations with a shorter observation period (missing follow-up or extraction because of endodontic reasons) and crowns with radiographically visible secondary caries or requiring rerestoration within this period were excluded. The time period of 6 months was defined as relevant because postendodontic restorations are usually performed within a few months after root canal treatment ${ }^{14-17}$, indicating that early rerestorations were already justified at the time of root canal treatment.

\section{Outcome}

All repaired restorations still in situ without any further interventions until the date of censoring (last checkup) were considered as survived ${ }^{18}$. Removal, replacement, loss, or recementation of the repaired crown or retainer restoration or replacement of the access restoration were defined as failure (event). The date of the intervention was considered as the time point when the restoration had failed. Censoring was performed when the intervention was not related to failure of the repaired restoration (eg, nonsurgical retreatment or tooth extraction).

\section{Statistical Analysis}

Statistical analysis was performed using $R$ software (Version 3.6.1; The R Foundation, Vienna, Austria [www.r-project.org]) and the packages "survminer" (Version 0.4.5), "survival" (Version 2.44-1.1), and "dplyr" (Version 0.8.3). The level of significance was set at $\alpha=0.05$.

The longevity of restorations with repaired endodontic access cavities was assessed up to 10 years by Kaplan-Meier statistics. The mean annual failure rates (mAFRs) were calculated at different time intervals $(2,5,7$, and 10 years, if available) by the following formula ${ }^{19}$ :

$$
\begin{aligned}
& (1-y)^{z}=1-x \\
& y=1-\sqrt[z]{1-x}
\end{aligned}
$$

where $y=\operatorname{mAFR}, x=$ the failure rate, and $z=$ the number of observation years.

Log-rank tests were used to assess the univariate effect of individual-, tooth-, and restoration-related variables. Subsequently, variables with a significant effect $(P<.05)$ were used in a multivariate Cox regression model with shared frailty to identify hazard ratios and their respective 95\% confidence intervals of factors associated with failure. Hence, shared frailty of correlated observations (restorations within the same patient) was taken into account.

\section{RESULTS}

A total of 270 restorations with composite access restorations were initially screened. After the exclusion of 90 restorations, 180 repaired crowns and retainer restorations placed in 151 patients were included in the analysis (4.5 \pm 3.3 years follow-up, Fig. 1). Patient characteristics, included restorations, and treatment variables included in the univariate analyses are presented in Table 1. Within 10 years after repair, 28 restorations (15.6\%) were censored because of nonsurgical retreatment $(n=23)$ or extraction $(n=5)$, and 53 restorations (29.4\%) failed (Fig. 1); 46 restorations were removed/ lost/replaced, 5 restorations required only rerestoration of the endodontic access cavity, and 2 restorations required recementation.

TABLE 2 - Variables Significant in the Univariate Analyses Were Submitted to the Multivariate Cox Regression Analysis (P Values and Hazard Ratio [HR])

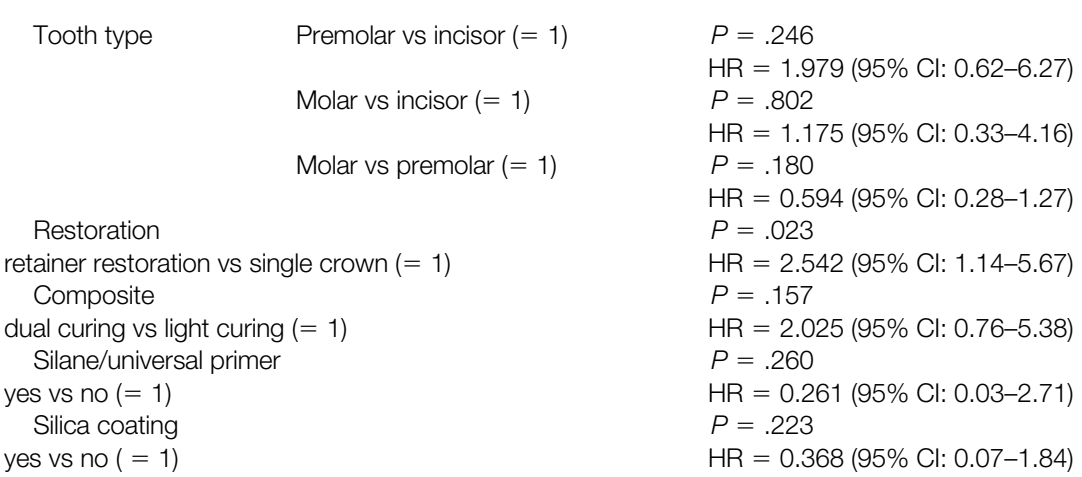

$\mathrm{Cl}$, confidence interval.

The survival rate of repaired restorations after $2,5,7$, and 10 years amounted to $82.7 \%, 71.5 \%, 67.3 \%$, and $48.8 \%$ (mAFRs $=9.0 \%, 6.5 \%, 5.5 \%$, and $6.9 \%)$, respectively. The Kaplan-Meier survival graph, the number of restorations at risk, and the mean AFRs are shown in Figure 2. The median survival time amounted to 9.65 (95\% confidence interval: 7.31-11.99) years. The date of cementation of the original restoration was known in 84 cases (mean age at time of repair $=4.5 \pm 4.0$ years); in the remaining cases, crowns were placed before 2000 or outside the clinic. For these 84 cases, the median survival time of the repaired restoration amounted to 12.7 years.

In the univariate analyses, the longevity of repaired restorations depended on several variables (Table 1). In the Cox regression model, only the kind of restoration (single crown $>$ retainer) remained significantly associated with survival ( $P=.023$, Table 2). Repaired crowns showed a lower mAFR than repaired retainer restorations (5-year $\mathrm{mAFR}=$ $3.5 \%$ and $11.8 \%$, respectively; Fig. 3).

\section{DISCUSSION}

This study showed that the repair of endodontic access cavities with composite increases the longevity of single crowns and retainer restorations and is able to postpone the placement of a new restoration. The overall median survival time of repaired crowns amounted to 9.7 years. Survival might be improved slightly further when considering that 7 of 53 failures allowed for rerestoration of the access cavity or recementation of the restoration without making replacement of the original restoration necessary. Repairs might be especially relevant for patients otherwise requiring complex and expensive renewal of fixed or removable prostheses. However, the survival of repaired retainer restorations of fixed or removable dental prosthesis was significantly lower than the survival of repaired single crowns. This observation is in line with earlier studies showing that the survival of telescopic crowns or fixed dental prostheses on vital ${ }^{20}$ and endodontically treated teeth ${ }^{12}$ is mostly lower than that of single crowns. Although repair was shown to increase the overall survival of the restorations, it has to be taken into consideration that repaired crowns might have a lower survival when compared with new (replaced) crowns on endodontically treated teeth ${ }^{12}$.

Because of the retrospective design of the study, the analysis comes along with the following methodological limitations that need to be addressed: 


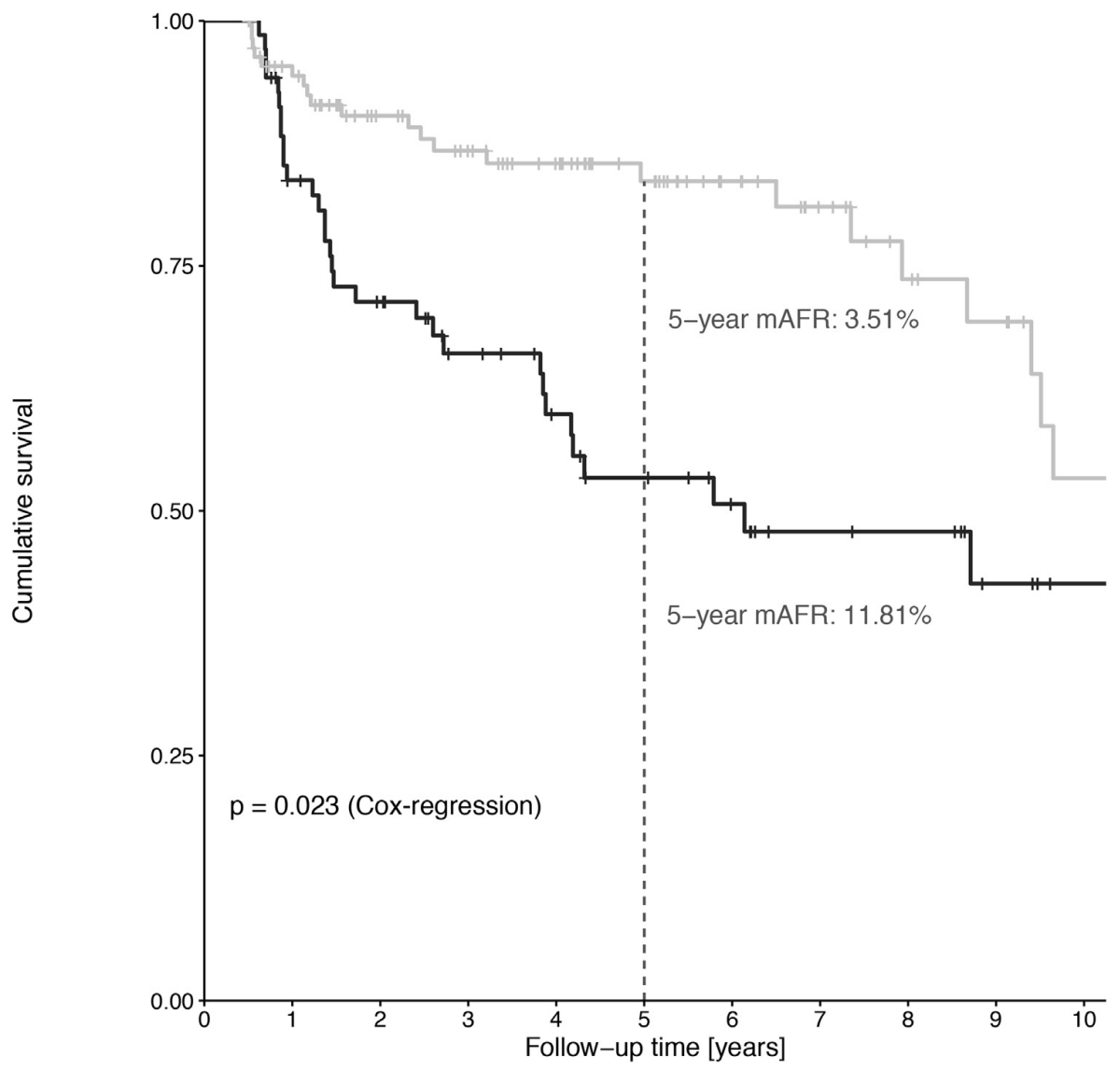

Restorations at risk:

\begin{tabular}{|c|c|c|c|c|c|c|c|c|c|c|c|}
\hline (Partial-) crown & 111 & 97 & 78 & 70 & 60 & 46 & 35 & 26 & 19 & 16 & 10 \\
\hline \multirow[t]{3}{*}{ Retainer } & 69 & 55 & 45 & 35 & 28 & 23 & 18 & 13 & 12 & 7 & 4 \\
\hline & 0 & 1 & 2 & 3 & 4 & 5 & 6 & 7 & 8 & 9 & 10 \\
\hline & \multicolumn{11}{|c|}{ Follow-up time [years] } \\
\hline
\end{tabular}

FIGURE 3 - The Kaplan-Meier survival graph (over 10 years) of repaired single (partial) crowns and retainer restorations ( $P$ value from multivariate Cox regression). The number of repaired restorations at risk and the mAFRs after 5 years are presented.

1. Thestatus oftherepairedcrownsand retainer restorations was obtained from electronic and paper-based patient records rather than by clinical examination. Consequently, in many cases, failure of the repaired restoration cannot be clearly attributed to failure of the composite repair itself, another intervention at the repaired crown/retainer (eg, because of secondary caries at the margin of the restoration), or both.
2. Restorations might have been replaced or further repaired by dentists in private practices during the follow-up period without our knowledge.

3. Because endodontic treatment and, if necessary, further restorative treatment of the repaired crown was performed by various dentists, quality assessment of the restoration and/or the repair by different operators might lead to further inaccuracies, affecting the validity of the

data.

4. Treatment procedures that might affect the bond strength of the repair (eg, the sequence of endodontic irrigation solutions and the duration of irrigation) or retention of the restoration (eg, the size of the endodontic access cavity and the ratio of the access cavity to the crown size) could not be obtained from the records. 
The univariate analyses indicate that the type of tooth as well as the repair conditioning techniques also affect survival. Repaired restorations on anterior teeth tend to present a higher survival than repaired posterior restorations, which also reflects the overall survival of single crowns ${ }^{4,21}$ and fixed dental prosthesis $^{22}$ on anterior or posterior teeth. Regarding the conditioning of the repaired surfaces, silica coating or sandblasting and the application of silane, alloy primer, or universal primer are frequently recommended for the repair of metal and ceramic surfaces ${ }^{23}$ and were shown to increase repair bond strength in vitro ${ }^{24}$. In the present study, both silica coating and the application of silane/universal primer increased survival in the univariate analysis; however, because of the overall low number of restorations treated by repair conditioning methods, the overall validity of this result is limited.

Although the overall sample size of the study was restricted to 180 restorations, the statistical analysis indicated an overall significant Cox regression model, which gives some information on factors that might influence or not the successful repair of endodontic access cavities.

In conclusion, this retrospective study showed that repairing endodontic access cavities with composite increases the longevity of single crowns and retainer restorations. However, further studies with a larger data set are required to identify potential treatment factors that might affect successful repair.

\section{ACKNOWLEDGMENTS}

This research did not receive any specific grant from funding agencies in the public, commercial, or not-for-profit sectors. The authors deny any conflicts of interest related to this study.

\section{REFERENCES}

1. Kanzow P, Hoffmann R, Tschammler C, et al. Attitudes, practice, and experience of German dentists regarding repair restorations. Clin Oral Investig 2017;21:1087-93.

2. Kanzow P, Dieckmann P, Hausdörfer $T$, et al. Repair restorations: questionnaire survey among dentists in the Canton of Zurich, Switzerland. Swiss Dent J 2017;127:300-11.

3. Sailer I, Makarov NA, Thoma DS, et al. All-ceramic or metal-ceramic tooth-supported fixed dental prostheses (FDPs)? A systematic review of the survival and complication rates. Part I: single crowns (SCs). Dent Mater 2015;31:603-23.

4. Pjetursson BE, Sailer I, Zwahlen M, Hämmerle $\mathrm{CH}$. A systematic review of the survival and complication rates of all-ceramic and metal-ceramic reconstructions after an observation period of at least 3 years. Part I: single crowns. Clin Oral Implants Res 2007;18:73-85.

5. Cheung GS, Lai SC, Ng RP. Fate of vital pulps beneath a metal-ceramic crown or a bridge retainer. Int Endod J 2005;38:521-30.

6. Valderhaug J, Jokstad A, Ambjørnsen E, Norheim PW. Assessment of the periapical and clinical status of crowned teeth over 25 years. J Dent 1997;25:97-105.

7. Siqueira Jr JF, Rôças IN, Ricucci D, Hülsmann M. Causes and management of post-treatment apical periodontitis. Br Dent J 2014;216:305.

8. Lynch CD, Hale R, Chestnutt IG, Wilson NH. Reasons for placement and replacement of crowns in general dental practice. Br Dent J 2018;225:229-34.

9. Uzgur R, Uzgur Z, Colak H, et al. A cross-sectional survey on reasons for initial placement and replacement of single crowns. Eur J Prosthodont Restor Dent 2017;25:42-8.

10. Schwartz R, Fransman R. Adhesive dentistry and endodontics: materials, clinical strategies and procedures for restoration of access cavities: a review. J Endod 2005;31:151-65.

11. Scioscia A, Helfers A, Soliman S, et al. Performance of monolithic and veneered zirconia crowns after endodontic treatment and different repair strategies. Oper Dent 2018;43:170-9.

12. Skupien JA, Opdam N, Winnen R, et al. A practice-based study on the survival of restored endodontically treated teeth. J Endod 2013;39:1335-40.

13. Gorman CM, Ray NJ, Burke FM. The effect of endodontic access on all-ceramic crowns: a systematic review of in vitro studies. J Dent 2016;53:22-9.

14. Mitov G, Dörr M, Nothdurft FP, et al. Post-endodontic treatment of incisors and premolars among dental practitioners in Saarland: an interactive Web-based survey. Clin Oral Investig 2015;19:1029-37.

15. Stenhagen S, Skeie H, Bårdsen A, Laegreid T. Influence of the coronal restoration on the outcome of endodontically treated teeth. Acta Odontol Scand 2019. https://doi.org/10.1080/ 00016357.2019 .1640390 .

16. Pratt I, Aminoshariae A, Montagnese TA, et al. Eight-year retrospective study of the critical time lapse between root canal completion and crown placement: its influence on the survival of endodontically treated teeth. J Endod 2016;42:1598-603. 
17. Yee K, Bhagavatula P, Stover S, et al. Survival rates of teeth with primary endodontic treatment after core/post and crown placement. J Endod 2018;44:220-5.

18. Laske M, Opdam NJ, Bronkhorst EM, et al. The differences between three performance measures on dental restorations, clinical success, survival and failure: a matter of perspective. Dent Mater 2019;35:1506-13.

19. Opdam NJ, Bronkhorst EM, Loomans BA, Huysmans MC. 12-year survival of composite vs. amalgam restorations. J Dent Res 2010;89:1063-7.

20. Reitemeier B, Hänsel K, Range U, Walter MH. Prospective study on metal ceramic crowns in private practice settings: 20-year results. Clin Oral Investig 2019;23:1823-8.

21. Miura S, Kasahara S, Yamauchi S, et al. Clinical evaluation of zirconia-based all-ceramic single crowns: an up to 12-year retrospective cohort study. Clin Oral Investig 2018;22:697-706.

22. Thoma DS, Sailer I, Ioannidis A, et al. A systematic review of the survival and complication rates of resin-bonded fixed dental prostheses after a mean observation period of at least 5 years. Clin Oral Implants Res 2017;28:1421-32.

23. Kanzow P, Wiegand A, Schwendicke F, Göstemeyer G. Same, same, but different? A systematic review of protocols for restoration repair. J Dent 2019;86:1-16.

24. Hickel R, Brüshaver K, llie N. Repair of restorations-criteria for decision making and clinical recommendations. Dent Mater 2013;29:28-50. 


\title{
Cost-effectiveness of repairing versus replacing composite or amalgam restorations
}

\author{
Philipp Kanzow ${ }^{\mathrm{a}, *}$, Annette Wiegand ${ }^{\mathrm{a}}$, Falk Schwendicke ${ }^{\mathrm{b}}$ \\ a Department of Preventive Dentistry, Periodontology and Cariology, University Medical Center Göttingen, Germany \\ ${ }^{\mathrm{b}}$ Department of Operative and Preventive Dentistry, Charité-Universitätsmedizin Berlin, Germany
}

\section{A R T I C L E I N F O}

Article history:

Received 26 April 2016

Received in revised form 24 August 2016

Accepted 25 August 2016

\section{Keywords:}

Restoration repair

Decision-making

Economic evaluation

Mathematical modelling

Minimally invasive dentistry

Restorative dentistry

\begin{abstract}
A B S T R A C T
Objectives: Repairing instead of replacing partially defective composite or amalgam restorations might reduce the initial treatment risks and costs, but could be less advantageous long-term due to repeated reinterventions being required. This study aimed to compare the cost-effectiveness of repairing versus replacing composite or amalgam restorations.

Methods: A mixed public-private-payer perspective from the German healthcare setting was adopted. A permanent molar with a three-surfaced partially defective composite or amalgam restoration in need of repair or replacement was modelled. Risks of complications after repair or complete replacement were derived by a rapid systematic literature review. The health outcome measure was tooth retention years. Costs were estimated from the German public and private fee catalogues. Monte-Carlo microsimulations were performed and incremental-cost-effectiveness ratios (ICERs) were used to express cost differences per gain or loss of effectiveness.

Results: Compared with complete composite replacement, composite repairs were marginally more costly and more effective ( $€ 326$ versus $€ 321 ; 24.7$ versus 24.0 years; ICER: $€ 7.14$ ). Amalgam repairs were more costly and more effective than complete replacement ( $€ 467$ versus $€ 326 ; 24.3$ versus 23.7 years; ICER: $€ 235$ ). If composite repair costs were $€<67$ or complete replacement costs $€>166$, composite repair was always cost-effective. This was not the case for amalgam repair. The size of the restoration, the reason for repair/replacement, and patients' age were found to influence the cost-effectiveness.

Conclusions: Repair was found to be more effective, but not necessarily less costly than complete replacement of restorations.

Clinical significance: Repairing instead of replacing partially defective restorations is likely to retain teeth for longer compared with complete replacement. When considering cost-effectiveness, repairing composite can be recommended more strongly than repairing amalgam restorations.
\end{abstract}

(c) 2016 Elsevier Ltd. All rights reserved.

\section{Introduction}

Treatment of failed restorations constitutes up to 60 percent of all treatments performed by general dentists [1-5]. Traditionally, all partially defective restorations are completely replaced, as limited defects are considered to irreversibly damage the entire restoration. However, more recently, the repair of defective restorations has become more prevalent as it is generally accepted that the repeated replacement of partially defective restorations results in the unnecessary removal of healthy dental hard tissue [6-8], which may increase the risk of pulpal complications over

\footnotetext{
* Corresponding author at: Department of Preventive Dentistry, Periodontology and Cariology, University Medical Center Göttingen, Robert-Koch-Str. 40, 37075 Göttingen, Germany.
}

E-mail address: philipp.kanzow@med.uni-goettingen.de (P. Kanzow). time [9-11]. Nowadays, repair restorations are well accepted by dentists and patients [9], although official guidelines concerning indications, repair techniques and materials are still scarce [12].

Repair restorations are not only considered to preserve tooth substance and reduce the risk of treatment-related complications, but might also take less time, as they involve only limited removal of existing restorations, often without anesthesia. Repair might also require reduced efforts compared with replacing restorations [13]. As a result, repairs might be less costly than complete replacement of defective restorations. That said, the survival probability of repair restorations might be inferior to that of replaced restorations $[14,15]$, which might compensate for any initial cost and effectiveness advantages of repair.

In order to compare both treatment options (complete replacement vs repair) and to define a cost-effective strategy to treat defective restorations, the present study aimed to investigate 
long-term cost-effectiveness of repair and complete replacement of partially defective amalgam and composite restorations.

\section{Methods}

Reporting of this study followed the Consolidated Health Economic Evaluation Reporting Standards (CHEERS) guidelines [16].

\subsection{Setting, perspective, population, horizon}

This study adopted a mixed public-private-payer perspective in the context of the German healthcare setting. We modelled a population of 100060 -year old females with one permanent molar with a vital non-painful pulp and a three-surfaced composite or amalgam restoration in need of repair or replacement. The tooth was followed over the patient's lifetime. The resulting time horizon was 26 years. To avoid clustering effects and simplify modelling and interpretation of findings, only one restoration per mouth was simulated. Restoration surface numbers and the time horizon were varied in sensitivity analyses (see below).

\subsection{Comparators}

We compared restoration repair versus complete replacement:

- Restoration repair was defined as mending a number of possible complications like tooth (cusp) or restoration fracture, partial restoration loss, secondary caries, or aesthetic reasons. Such mending was performed by partially replacing the original restoration with adhesively placed composite resin and assumed to involve only one surface. Note that we did not assume repair to be provided according to any specific standard. Also note that performing any further conditioning procedures, like application of silane or silica coating, might increase costs of repair, but could also affect effectiveness [12].

- Complete replacement of the partially defective amalgam and composite restorations was defined as completely removing and replacing the failed restoration either with amalgam or adhesively placed resin composite (depending on the initial, failed restoration) and increasing the restoration surface by +1 .

\subsection{Model and assumptions}

A Markov model was used for this study (TreeAge Pro 2013, TreeAge Software, Williamstown, MA, USA).

Complications of both repaired and replaced restorations were assumed to lead to

- Restorative re-treatments like re-replacement or re-repair (possible reasons might be fracture, including partial loss of restoration and tooth fracture with or without retention loss, secondary caries, or primary caries).

- Repaired restorations could not be repaired again, but needed complete restoration replacement.

- Complete restoration replacement was assumed to generate an additional restoration surface and increased the risk of restorative failure and re-treatment by $1.4[17,18]$.

- We assumed a direct (composite, amalgam) restoration to have a maximum of five surfaces, therefore limiting the number of rereplacements.

- A full-metal crown was placed if replacements were not possible any longer.

- Endodontic treatment, i.e. root-canal treatment (assuming the treatment of a vital pulp including instrumentation and obturation), followed by placement of a crown (as could be expected after endodontic treatment in extensively restored teeth).

- Extraction for non-mendable complications.

The proportions of the different re-treatments were derived from a large, practice-based study, which had followed repaired and replaced restorations placed by the same operator in the same population of patients [14,19] (Appendix Table S1):

- In follow-up health states, teeth were again assumed to experience restorative complications (e.g. crown de-cementation, fracture or secondary caries, leading to re-cementation or renewal of crowns, or extractions) or endodontic complications (leading to non-surgical primary or secondary root-canal treatment or surgical re-treatment, i.e. apisectomy, or extraction).

- We assumed $50 \%$ of extracted teeth to be replaced using implantsupported single crowns. Implants were assumed to experience restorative complications (requiring re-cementation or renewal of crowns) as well as biologic (e.g. peri-implantitis, possibly with subsequent implant loss) or technical complications (like abutment or implant fracture).

The constructed model is shown in a simplified form in Fig. 1. Model validation was performed internally by varying key parameters to check their impact on the results, by evaluating different model structures, and by performing the following univariate sensitivity analyses:

- Repairs were assumed to be possible twice, not only once.

- Complete replacement did not add an additional surface to the restoration, but was only possible twice before crown placement was required.

- Between $0 \%$ and $100 \%$ of removed teeth were replaced using implant-supported crowns.

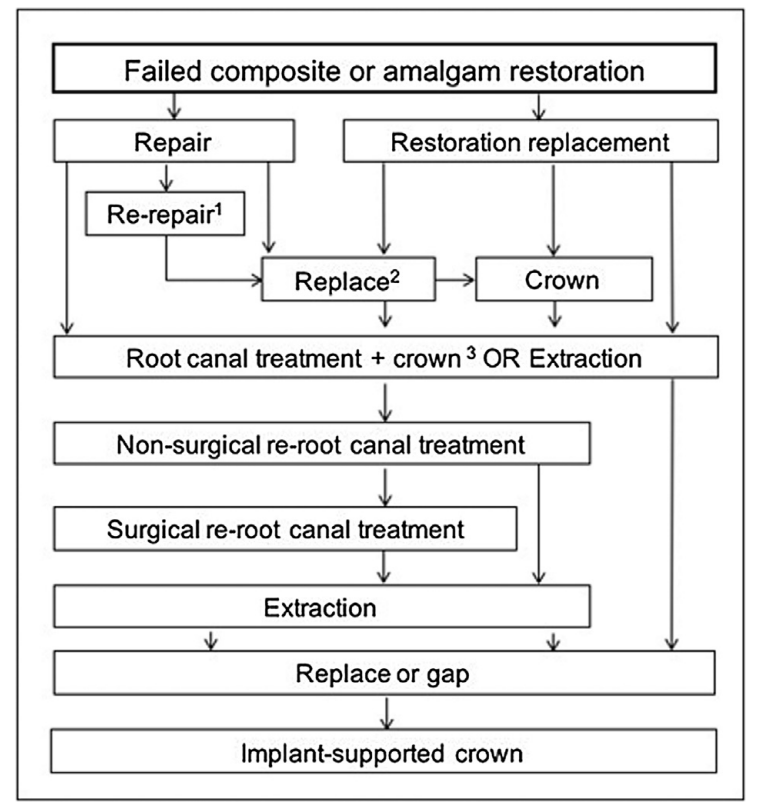

Fig. 1. Transition diagram

${ }^{1}$ Re-Repair was only possible in a sensitivity analysis. ${ }^{2}$ Number of repeated replacements was varied in sensitivity analysis. ${ }^{3}$ Crown was only placed after rootcanal treatment in case no crown was present. 
- The original restoration was assumed to involve four surfaces.

- The patient was assumed to be 40 years old at baseline, which increases the horizon of the simulation.

\subsection{Health outcome measure}

The health outcome measure was tooth retention years, i.e. the mean time a tooth was retained in a patients' mouth. This was determined by the tooth experiencing complications, the risk of which is modelled via transition probabilities, which allow teeth to move from one health state to another (i.e. risks of complications and associated re-treatments).

Transition probabilities for repaired versus new/replaced restorations were estimated based on a rapid systematic review of the literature (see Appendix).

Based on the included five studies (8 publications) $[14,15,20-$ 25], we estimated the risk of complications in repaired relative to those in new/replaced composite or amalgam restorations. While some studies were controlled [20,22-25], i.e. had randomly assigned restorations to repair or replacement, some were cohort studies $[14,15,21]$. For these, we took care to only compare risk of complications in repaired versus new/replaced restorations if they were performed on similar patients (age range, source population) under similar conditions (setting, operators). Note that in this case, indication bias is nevertheless likely, as placement of amalgam might be more frequent in certain (demographic, socio-economic) populations than placement of composite [26], which is why extensive sensitivity analyses were required to check the robustness of our findings. The relative risk of complications in repaired versus new/replaced restorations was estimated as sample-size weighted means and ranges of reported annual failure rates (AFR) (Appendix Table S3).

Risk of complications of new/replaced restorations were estimated from one large practice-based study [19], which had reported on large posterior amalgam and composite restorations. The AFR found in this study (1.7\% for composite and $2.4 \%$ for amalgam after 12 years) were validated by comparing them with findings from systematic reviews $[27,28]$ and other practice based studies [17,18], which found AFRs ranging from $1.1 \%$ to $2.2 \%$ for composite, and $2.1-3.0 \%$ for amalgam in posterior permanent teeth, i.e. of similar magnitude (see Appendix). The uncertainty of this estimate was reflected by randomly sampling between a triangular distribution between the minimum and maximum of these values. It should be born in mind that some of these studies evaluated both replaced and newly placed restorations, and not only replacements.

To allow the risk of complications in both repair and replacement to vary time-dependently (i.e. to reflect that risk of restorations failure is not constant with time), reported KaplanMeier curves were transformed into hazard functions. Risk of complications in follow-up states had been estimated for previous studies, mainly using systematic reviews, with full detail of estimation being described elsewhere $[29,30]$.

\subsection{Resources and costs}

German healthcare is characterized by a two-tiered insurance system. Cost calculations were based on the German public and private dental fee catalogues, BEMA and GOZ [31] providing an estimation of costs from the payers perspective, as described in the Appendix. Given the lack of primary data, opportunity costs of patients' time in treatment were not accounted for. Costs were estimated in 2015 Euro.

\subsection{Discounting}

Future costs and effectiveness were discounted at 3\% per annum, as recommended by German authorities [32]. Discounting accounts for opportunities forgone if spending money now instead of later, or gaining health benefits later instead of now [33]. Discount rates were varied between 0 and $5 \%$ in a sensitivity analysis.

\subsection{Analytical methods}

Analysis was performed using Monte Carlo micro simulations, with 1000 independent individuals (teeth) being followed over the average expected life-time of patients [34] in annual cycles. To introduce parameter uncertainty, we randomly sampled transition probabilities from a triangular distribution of parameters, as outlined above [35], with 100 random samples being drawn for each population of individuals/teeth.

Strategies were ranked according to their costs, and incremental-cost-effectiveness ratios (ICERs) used to express cost differences per gain or loss of effectiveness when comparing repair versus complete replacement. A positive ICER thus indicates additional costs per additional effectiveness (such a strategy is considered to be undominated), while negative ICERs indicate higher costs at lower effectiveness (such strategy is considered to be dominated by the alternative).

Using estimates for costs (c, in $€$ ) and effectiveness (e, in years), the net benefit of each strategy combination was calculated using the formula

net benefit $=\lambda \times \Delta \mathrm{e}-\Delta \mathrm{c}$,

with $\lambda$ denoting the ceiling threshold of willingness-to-pay, i.e. the additional costs a decision maker is willing to bear for gaining an additional unit of effectiveness [36]. If $\lambda>\Delta c / \Delta e$, an intervention is considered more cost-effective compared to the alternative despite possibly being more costly [35]. We used the net-benefit approach to calculate the probability of a detection strategy being acceptable regarding its cost-effectiveness for payers with different willingness-to-pay ceiling thresholds. A number of univariate sensitivity analyses were performed to explore the impact of uncertainty and heterogeneity. Details regarding the input variables for these analyses can be found in the Appendix (Appendix Table S4).

\section{Results}

\subsection{Study parameters}

Estimated effectiveness parameters, i.e. relative risks and transition probabilities, can be found in Table 1. Parameters underlying the sensitivity analyses can be found in the Appendix including Appendix Table S4. Costs for complete composite replacement were estimated to amount to $€ 159.80$, complete amalgam replacement to $€ 103.90$ and repair restorations (one-surfaced composite) to $€ 69.42$. Details on cost calculations can be found in the Appendix, along with per unit costs and quantities (Appendix Tables S5-S8).

\subsection{Base-case scenario}

For composite, repair was minimally more costly than complete replacement ( $€ 326$ versus $€ 321$ ), but also more effective (24.7 versus 24.0 tooth-retention years). Repair was thus undominated, with an incremental cost-effectiveness ratio (ICER) of $€ 7.14$ (Table 2, Fig. 2). Only payers willing to invest more than $€ 7.14$ 
Table 1

Parameters used for effectiveness estimation. Transition probabilities describe the chance of a tooth moving from one health state to another. Sources for these probabilities are given, as are the distribution of each parameter (which was used for random sampling of parameters). If a tooth experienced a transition, allocation probabilities describe to which health state allocation occurred.

\begin{tabular}{|c|c|c|c|c|c|}
\hline Health state & Reference & $\begin{array}{l}\text { Transition probability per } \\
\text { year }\end{array}$ & $\begin{array}{l}\text { Triangular } \\
\text { distribution }\end{array}$ & Allocation to & $\begin{array}{l}\text { Allocation } \\
\text { probability }\end{array}$ \\
\hline Repaired composite & Appendix & $\begin{array}{l}\mathrm{RR}=3.4 \text { relative to replaced } \\
\text { composite }\end{array}$ & $0.7 ; 1.0 ; 1.3$ & $\begin{array}{l}\text { Replaced or repaired composite } \\
\text { or amalgam }\end{array}$ & 0.85 \\
\hline \multirow[t]{2}{*}{ Repaired amalgam } & Appendix & $\begin{array}{l}\mathrm{RR}=5.0 \text { relative to replaced } \\
\text { amalgam }\end{array}$ & $0.5 ; 1.0 ; 1.5$ & Endodontic treatment + crown & 0.13 \\
\hline & & & & Extraction & 0.02 \\
\hline Replaced composite & Opdam et al. 2010 [19] & $0.0215 y^{-0.071}$ & $0.7 ; 1.0 ; 1.3$ & Re-replacement or crown & 0.72 \\
\hline \multirow[t]{2}{*}{ Replaced amalgam } & Opdam et al. 2010 [19] & $0.0074 y^{0.600}$ & $0.7 ; 1.0 ; 1.3$ & $\begin{array}{l}\text { Endodontic treatment and } \\
\text { crown }\end{array}$ & 0.10 \\
\hline & & & & Extraction & 0.08 \\
\hline \multirow[t]{2}{*}{ RCT vital with pain } & $\begin{array}{l}\text { Ricucci et al. } 2011 \text { [41]; Schwendicke and } \\
\text { Stolpe } 2014 \text { [30] }\end{array}$ & $0.0232 y^{-0.823}$ & - & Non-surgical re-RCT & 0.50 \\
\hline & & & & Extraction & 0.50 \\
\hline \multirow[t]{4}{*}{ Crown } & Burke and Lucarotti 2009 [42] & 0.056 & $0.7 ; 1.0 ; 1.3$ & Recementation & 0.40 \\
\hline & & & & Re-new & 0.20 \\
\hline & & & & RCT & 0.20 \\
\hline & & & & Extraction & 0.20 \\
\hline \multirow{2}{*}{ Non-surgical re-RCT } & Ng et al. 2008 [43] & 0.059 & $0.3 ; 1.0 ; 1.7$ & Surgical re-RCT & 0.80 \\
\hline & & & & Extraction & 0.20 \\
\hline Surgical re-RCT & Torabinejad et al. 2009 [44] & 0.080 & $0.5 ; 1.0 ; 1.5$ & Extraction & 1.00 \\
\hline \multirow[t]{2}{*}{ Implant loss } & Jung et al. 2012 [45] & 0.032 & $0.5 ; 1.0 ; 1.5$ & Renew & 0.50 \\
\hline & & & & Remove & 0.50 \\
\hline \multirow{2}{*}{$\begin{array}{l}\text { Implant crown } \\
\text { failure or loss }\end{array}$} & Jung et al. 2012 [45] & 0.047 & $0.6 ; 1.0 ; 1.4$ & Renewal & 0.40 \\
\hline & & & & Recementation & 0.60 \\
\hline
\end{tabular}

Table 2

Cost-effectiveness of different strategies in the base-case and sensitivity analyses. Costs (c, in $€$ ) and effectiveness (e, in years) are given for repair and replacement of composites and amalgams. The incremental cost-effectiveness ratio (ICER) describe the cost difference per effectiveness difference between strategies. Positive values indicate repair being more costly, but also more effective, while negative values indicate repair being both less costly and more effective.

\begin{tabular}{|c|c|c|c|c|c|c|c|c|c|c|}
\hline \multirow[t]{3}{*}{ Scenario } & \multicolumn{5}{|c|}{ Composite } & \multicolumn{5}{|c|}{ Amalgam } \\
\hline & \multicolumn{2}{|c|}{ Repair } & \multicolumn{2}{|c|}{ Replacement } & \multirow[t]{2}{*}{ ICER } & \multicolumn{2}{|c|}{ Repair } & \multicolumn{2}{|c|}{ Replacement } & \multirow[t]{2}{*}{ ICER } \\
\hline & c & e & c & e & & c & e & c & e & \\
\hline Base-case & 326 & 24.7 & 321 & 24.0 & 7.14 & 467 & 24.3 & 326 & 23.7 & 235.00 \\
\hline Original restoration is 4 -surfaced & 377 & 24.6 & 403 & 23.5 & -23.64 & 511 & 24.1 & 441 & 23.0 & 63.64 \\
\hline Repair is possible twice & 320 & 24.8 & 321 & 24.0 & -1.25 & 470 & 24.4 & 326 & 23.7 & 205.71 \\
\hline Replacement does not add surface & 327 & 24.7 & 309 & 24.1 & 30.00 & 465 & 24.3 & 311 & 23.7 & 256.67 \\
\hline Caries as original complication & 249 & 24.9 & 345 & 23.8 & -87.27 & 403 & 24.6 & 370 & 23.3 & 25.38 \\
\hline Fracture as original complication & 377 & 24.6 & 251 & 24.6 & $>10,000$ & 488 & 24.2 & 297 & 23.9 & 636.67 \\
\hline Patient aged 40 years & 471 & 38.1 & 432 & 36.8 & 30.00 & 654 & 36.6 & 545 & 35.2 & 77.86 \\
\hline No implant placed for extracted teeth & 283 & 24.7 & 249 & 24.0 & 48.57 & 387 & 24.3 & 220 & 23.7 & 278.33 \\
\hline All extracted teeth replaced with implants & 363 & 24.7 & 401 & 24.0 & -54.29 & 539 & 24.3 & 444 & 23.7 & 158.33 \\
\hline Discount rate $0 \%$ & 335 & 25.5 & 330 & 24.8 & 7.14 & 479 & 25.0 & 335 & 24.4 & 240.00 \\
\hline Discount rate $5 \%$ & 321 & 24.2 & 315 & 23.6 & 10.00 & 459 & 23.9 & 320 & 23.2 & 198.57 \\
\hline
\end{tabular}

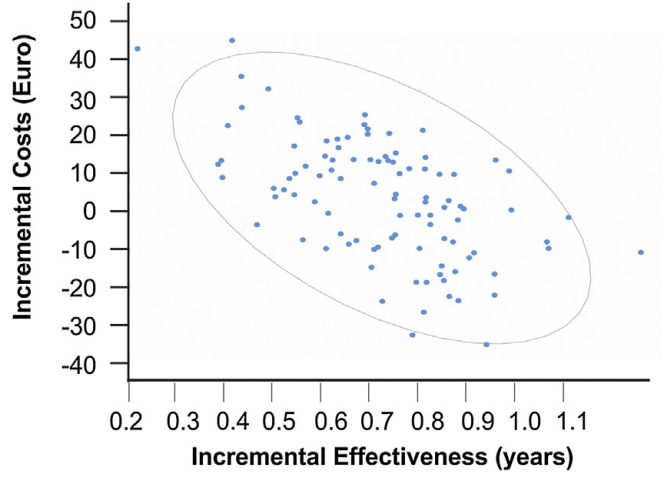

Fig. 2. Incremental cost-effectiveness plane.

Horizontal and vertical axes illustrate the effectiveness- and cost-differences between repair compared with replacement of composite restorations. The ellipsis represents the $95 \%$ confidence interval. Repair was always more effective, and in nearly half of the cases also less costly. per additional year of tooth retention found repair of composite restorations cost-effective (Fig. 3a).

For amalgam, repair was more costly than complete replacement $(€ 467$ versus $€ 326$ ) but more effective 24.3 versus 23.7 tooth-retention years) than complete replacement, i.e. again undominated. The resulting ICER was $€ 235$ per tooth retention year. Payers willing to invest more than this sum found repair of amalgam restorations cost-effective (Fig. 3b).

\subsection{Sensitivity analyses}

We varied the costs of repair and complete replacement.

For composite, repair was both less costly and more effective than complete replacement if repair costs were below $€ 67$ (complete replacement was dominated) (Fig. 3c). Similarly, repair was less costly and more effective than complete replacement if replacement costs were above $€ 166$ (Fig. 3d). For amalgam, even cost decreases below $€ 40$ for repair and increases above $€ 163$ for 

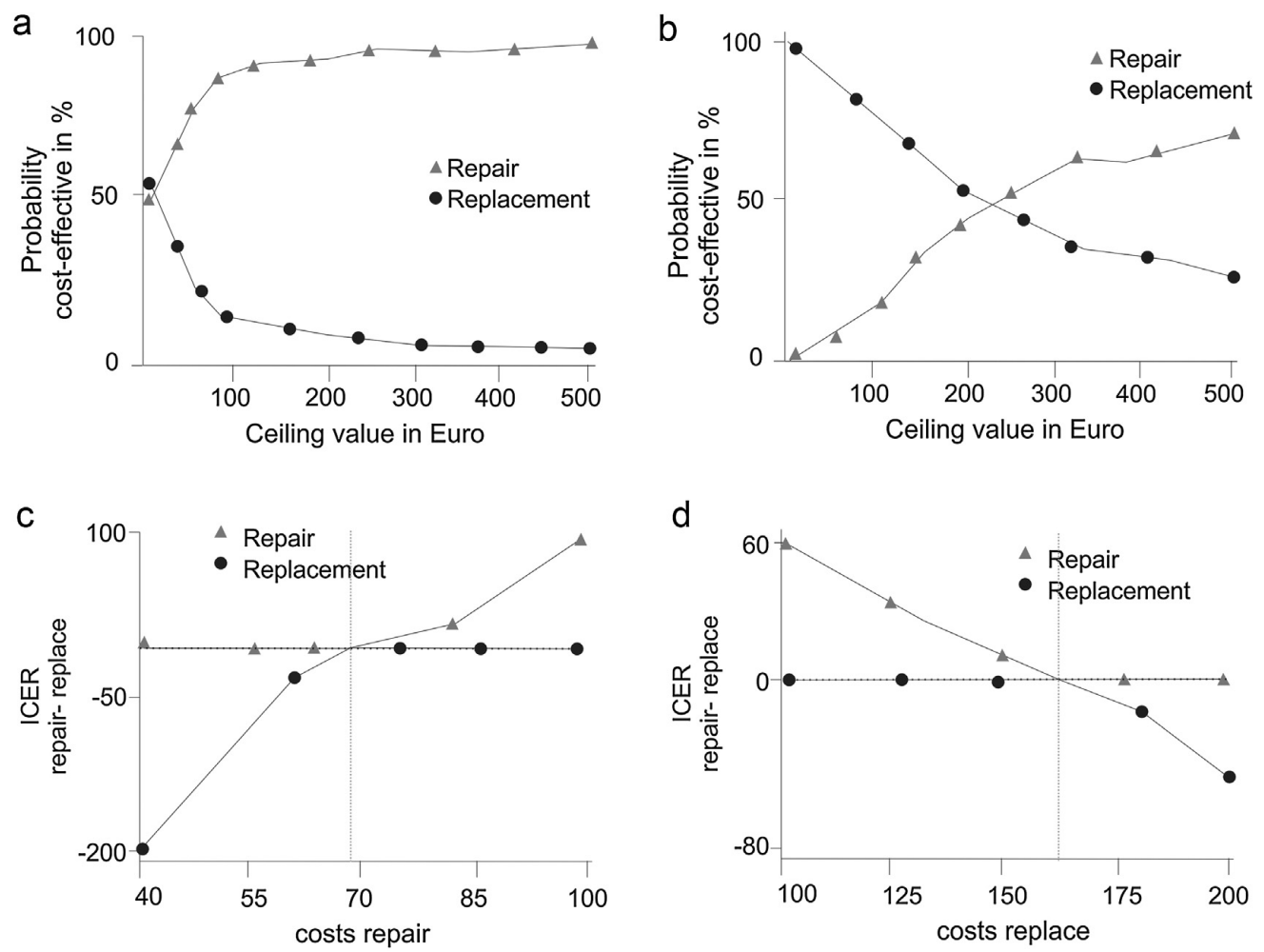

Fig. 3. Net-benefit/sensitivity analyses (a, b) and univariate microsimulation sensitivity analyses (c, d).

We plotted the probability of repair or replacement being acceptable in terms of its cost-effectiveness on the willingness-to-pay threshold of a payer: By increasing the willingness-to-pay, a treatment with higher effectiveness, but also higher costs becomes more acceptable. (a) Repair versus replacement of composite restorations, (b) repair versus replacement of amalgam restorations. Univariate microsimulation sensitivity analyses varying the costs for repair (c) or replacement (d) of composite restorations. ICERs were used to estimate the relative cost-effectiveness of both strategies. For repair, positive ICERs indicate it being more effective, but also more costly. For replacement, negative ICERs indicate it being less effective and more costly.

complete replacement did not lead to a changed ranking of strategies, i.e. repair remained undominated.

Further parameters were checked for their impact (Table 2):

- When assuming a 4-surfaced restoration to fail (with only one complete replacement being possible and higher risks of failure for both repaired and replaced restorations), repair of composites was both less costly and more effective than complete replacement, i.e. complete replacement was dominated. In contrast, repairing amalgams remained more costly and more effective than complete replacement, i.e. repair was undominated.

- If we assumed that repeated repair was possible, the ICERs for repair of both composite and amalgam decreased but remained positive (payers needed to be willing to invest additional money).

- Assuming that complete replacement did not lead to larger restorations had only limited impact.

- Assuming caries to be the reason for repair or replacement had significant impact, with composite repair being both much less costly and more effective than complete replacement (ICER $€-$ 87.27). Under the same assumption, amalgam repair was only minimally more costly than complete replacement (ICER $€ 25.38$ ).

- Assuming restoration fracture to be the reason for repair or replacement had significant impact as well. In this case, repair was not cost-effective, with ICERs far above $€ 600$ per year for both materials.
- If all lost teeth were to be replaced with implants, repair of composite restorations was less costly and more effective than complete replacement (this was not the case for amalgam).

- Varying the applied discount rates did not change the strategy rankings, with repair being more effective, but also more costly.

\section{Discussion}

Our calculations found restoration repair to be more effective than complete replacement to retain teeth, but not necessarily less costly. Based on the present cost-effectiveness analyses, repairing composite restorations is likely to be minimally more costly, but more effective than replacing them. The resulting ICER per tooth retention year, however, is hard to interpret given the absence of a defined acceptable value for retaining a single tooth for longer. When considering the overall costs for complete replacement or repair, investing additional money in the magnitude of $€ 7$ per year seems, however, reasonable. In contrast, repairing amalgam restorations is more effective, but probably also far more costly.

The higher cost-effectiveness of repairing composite compared to amalgam restorations is attributed to two reasons. Firstly, the replacement of amalgam restorations is less costly than composite restorations in the German health care system, resulting in lower cost-differences for repair versus complete replacement of amalgam restorations. Secondly, the longevity of repaired amalgam restorations is slightly lower than that of repaired composites [14]. It should be noted that replacing existing amalgam 
restorations with new amalgams might be less common nowadays due to controversies regarding its safety and national as well as global efforts to limit or even ban its use in dentistry [37,38]. Instead, repair could be compared with placement of large composite or ceramic restorations which is likely to change our cost-effectiveness ranking.

The results of the present study are limited by the quantity and quality of the data we based our assumptions on. First, only few studies were available to compare risk of failure in restoration repair versus complete replacement with the majority of studies reporting selection bias as restorations were not randomly assigned to repair or replacement $[14,15,21]$. Moreover, indications of repair differed widely between studies, which highlights the fact that no agreed (or applicable) guideline of when to repair and when not to exists [12].

Secondly, the majority of included studies found repair restorations to fail more frequently than new or replaced ones $[14,15,22]$. However, in most of them full data on how exactly failure occurred were missing, which impacts on allocation probabilities (how is a complication mended?). We used one large practice-based study to estimate risk of failure in replaced restorations [14,19], and also built a number of further estimates on this study (Appendix Table S4). However, this study assessed newly rather than replaced restorations; the true effectiveness of complete replacements is likely to be lower, with replaced restorations being likely to fail earlier. Our estimates should thus be considered as conservative, with repair being possibly more cost-effective. To account for this uncertainty, we varied risks over wide ranges, and found our results to be only minimally being affected.

Third, this study made a number of assumptions which might be debated: For example, we assumed repair restorations to consist of a one-surfaced composite restoration, while complete replacement increased the restoration surface by +1 . Repair of small defects like marginal ditching or staining might require even lesser efforts than assumed here, which could improve the costeffectiveness of repair restorations, while complete replacement might not always increase the size of the restoration. Both aspects were submitted to sensitivity analyses and did not change our rankings.

Last, our cost-estimation was based on the German healthcare system. Transferability of our findings to other healthcare systems cannot be assumed. Moreover, costs for repair and complete replacement had great impact on the cost-effectiveness. We explored the effects of uncertainty of costs by varying them within wide intervals. For composites, we found that repair needed to be approximately half as expensive as complete replacement (repair $€<67$; complete replacement $€>166$ ) to be overall less costly (i.e. to compensate for higher risk of complications and re-treatment costs). For amalgam, even very low repair $(€<40)$ and very high replacement costs $(€>163$ ) could not compensate for the higher risk of failure in repaired amalgams.

When secondary caries was the reason for failure of the original restoration, restoration repair was significantly more cost-effective than complete replacement.

In contrast, repair of fractured restorations was associated with relatively high risk of failure in repaired restorations [14] and very limited cost-effectiveness of this strategy. As fractured restorations might fail due to high forces being applied, it can be assumed that repair restorations are not more, but less able to withstand these forces, making repair a less than optimal strategy for this indication.

In contrast, caries lesion occurrence does not so much depend on the restoration material as it does on patients' individual caries risk $[19,39,40]$. Repairing a restoration will not alter this risk, but repaired restorations will not suffer from significantly increased risk of failure compared with replaced restorations. That could make repair an attractive treatment in high-risk caries patients.

Repair was more cost-effective in larger than smaller restorations. Moreover, risk of failure of large replaced restorations is usually higher than that of smaller restorations, which we accounted for accordingly [18]. Cost-effectiveness of repair increased further when assuming that repeated repair was possible. It remains unclear if such repetition of repairs is always feasible, but might well be accepted by patients who had accepted repairs in the first place. It should be highlighted that indications for repair might not always be given, and that treatment decisions will further need to account for preferences of both patients and dentists as well as practical aspects (available time, materials, staff and equipment).

In conclusion and within the limitations of the present study, repairing instead of replacing partially defective restorations is likely to retain teeth for longer compared with full replacement For composite restorations, repair is likely to be only minimally more costly, while for amalgams, repair might be a far more expensive strategy than complete replacement. When considering further factors, repair was most suitable in large composite restorations which had failed due to secondary caries. In contrast repairing fractured composite or amalgam restorations does not seem cost-effective compared with complete replacement. In light of the identified uncertainty and bearing in mind the variety of indications for repair versus full replacement, clinical decisionmaking should consider further factors besides cost-effectiveness like patients' and dentists' preferences, or practical aspects like the available treatment time or equipment.

\section{Conflict of interest}

The authors declare no conflict of interest.

\section{Acknowledgement}

This study was funded by the authors and their institutions.

\section{Appendix A. Supplementary data}

Supplementary data associated with this article can be found, in the online version, at http://dx.doi.org/10.1016/j. jdent.2016.08.008.

\section{References}

[1] S.R. Braga, B.T. Vasconcelos, M.R. Macedo, V.R. Martins, M.A. Sobral, Reasons for placement and replacement of direct restorative materials in brazil, Quintessence Int. 38 (4) (2007) e189-94.

[2] I.A. Mjör, J.E. Dahl, J.E. Moorhead, Placement and replacement of restorations in primary teeth, Acta Odontol. Scand. 60 (1) (2002) 25-28.

[3] M.J. Tyas, Placement and replacement of restorations by selected practitioners, Aust. Dent. J. 50 (2) (2005) 81-89 quiz 127.

[4] A.R. Al Negrish, Reasons for placement and replacement of amalgam restorations in Jordan, Int. Dent. J. 51 (2) (2001) 109-115.

[5] N.A. Chrysanthakopoulos, Placement, replacement and longevity of composite resin-based restorations in permanent teeth in Greece, Int. Dent. J. 62 (3) (2012) 161-166.

[6] V.V. Gordan, Clinical evaluation of replacement of class V resin based composite restorations, J. Dent. 29 (7) (2001) 485-488.

[7] V.V. Gordan, In vitro evaluation of margins of replaced resin-based composite restorations, J. Esthet. Dent. 12 (4) (2000) 209-215.

[8] V.V. Gordan, E. Mondragon, C. Shen, Replacement of resin-based composite: evaluation of cavity design, cavity depth, and shade matching, Quintessence Int. 33 (4) (2002) 273-278.

[9] P. Kanzow, R. Hoffmann, C. Tschammler, J. Kruppa, T. Rödig, A. Wiegand, Attitudes, practice and experience of German dentists regarding repair restorations, Clin. Oral Invest. (2016), doi:http://dx.doi.org/10.1007/s00784restorations,

[10] V.V. Gordan, J. Riley 3rd., S. Geraldeli, O.D. Williams, J.C. Spoto 3rd., G.H. Gilbert, National Dental PBRN Collaborative Group, The decision to repair or replace a defective restoration is affected by who placed the original 
restoration: findings from the National Dental PBRN, J. Dent. 42 (12) (2014) 1528-1534.

[11] V.V. Gordan, J.L. Riley 3rd., S. Geraldeli, D.B. Rindal, V. Qvist, J.L. Fellows, H.P. Kellum, G.H. Gilbert, Dental Practice-Based Research Network Collaborative Group, Repair or replacement of defective restorations by dentists in The Dental Practice-Based Research Network, J. Am. Dent. Assoc. 143 (6) (2012) Dental Pro1.

[12] R. Hickel, K. Brüshaver, N. Ilie, Repair of restorations-criteria for decision making and clinical recommendations, Dent. Mater. 29 (1) (2013) 28-50.

[13] I.R. Blum, K. Hafiana, A. Curtis, M.E. Barbour, T. Attin, C.D. Lynch, D.C. Jagger, The effect of surface conditioning on the bond strength of resin composite to amalgam, J. Dent. 40 (1) (2012) 15-21.

[14] N.J. Opdam, E.M. Bronkhorst, B.A. Loomans, M.C. Huysmans, Longevity of repaired restorations: a practice based study, J. Dent. 40 (10) (2012) 829-835.

[15] R.J. Smales, W.S. Hawthorne, Long-term survival of repaired amalgams, recemented crowns and gold castings, Oper. Dent. 29 (3) (2004) 249-253.

[16] D. Husereau, M. Drummond, S. Petrou, C. Carswell, D. Moher, D. Greenberg, F. Augustovski, A.H. Briggs, J. Mauskopf, E. Loder, C.T. Force, Consolidated health economic evaluation reporting standards (CHEERS) statement, BMJ 346 (2013) f1049.

[17] N.J. Opdam, E.M. Bronkhorst, J.M. Roeters, B.A. Loomans, A retrospective clinical study on longevity of posterior composite and amalgam restorations, Clinical study on longevity of poste
Dent. Mater. 23 (1) (2007) 2-8.

[18] P.A. Da Rosa Rodolpho, T.A. Donassollo, M.S. Cenci, A.D. Loguercio, R.R. Moraes, E.M. Bronkhorst, N.J. Opdam, F.F. Demarco, 22-Year clinical evaluation of the performance of two posterior composites with different filler characteristics, Dent. Mater. 27 (10) (2011) 955-963.

[19] N.J. Opdam, E.M. Bronkhorst, B.A. Loomans, M.C. Huysmans, 12-year survival of composite vs. amalgam restorations, J. Dent. Res. 89 (10) (2010) 1063-1067.

[20] J. Martin, E. Fernandez, J. Estay, V.V. Gordan, I.A. Mjor, G. Moncada, Minimal invasive treatment for defective restorations: five-year results using sealants, Oper. Dent. 38 (2) (2013) 125-133.

[21] V.V. Gordan, J.L.r. Riley, P.K. Blaser, E. Mondragon, C.W. Garvan, I.A. Mjör, Alternative treatments to replacement of defective amalgam restorations: results of a seven-year clinical study, J. Am. Dent. Assoc. 142 (7) (2011) 842849.

[22] E.M. Fernández, J.A. Martín, P. Vildósola, O.B. Oliveira Junior, V.V. Gordan, I.A. Mjör, C. Bersezio, J. Estay, M.F. de Andrade, G.A. Moncada, Can repair increase the longevity of composite resins? Results of a 10-year clinical trial, J. Dent. 43 (2) (2015) 279-286.

[23] E.M. Fernández, J.A. Martin, P.A. Angel, I.A. Mjör, V.V. Gordan, G.A. Moncada, Survival rate of sealed, refurbished and repaired defective restorations: 4-year follow-up, Braz. Dent. J. 22 (2) (2011) 134-139.

[24] G. Moncada, J. Martin, E. Fernández, M.C. Hempel, I.A. Mjör, V.V. Gordan, Sealing, refurbishment and repair of class I and class II defective restorations, J. Am. Dent. Assoc. 140 (4) (2009) 425-432.

[25] G. Moncada, E. Fernandez, J. Martin, C. Arancibia, I.A. Mjor, V.V. Gordan, Increasing the longevity of restorations by minimal intervention: a two-year clinical trial, Oper. Dent. 33 (3) (2008) 258-264.

[26] G. Alexander, M.S. Hopcraft, M.J. Tyas, R.H. Wong, Dentists' restorative decision-making and implications for an 'amalgamless' profession. Part 2: a qualitative study, Aust. Dent. J. 59 (4) (2014) 420-431.

[27] J. Manhart, H. Chen, G. Hamm, R. Hickel, Buonocore memorial lecture. Review of the clinical survival of direct and indirect restorations in posterior teeth of the permanent dentition, Oper. Dent. 29 (5) (2004) 481-508.

[28] F. Schwendicke, G. Göstemeyer, U. Blunck, S. Paris, L.Y. Hsu, Y.K. Tu, Directly placed restorative materials: review and network meta-analysis, J. Dent. Res. 95 (6) (2016) 613-622.
[29] F. Schwendicke, C. Graetz, M. Stolpe, C.E. Dörfer, Retaining or replacing molars with furcation involvement: a cost-effectiveness comparison of different strategies, J. Clin. Periodontol. 41 (11) (2014) 1090-1097.

[30] F. Schwendicke, M. Stolpe, Direct pulp capping after a carious exposure versus root canal treatment: a cost-effectiveness analysis, J. Endod. 40 (11) (2014) root canal tre

[31] KZBV, Catalogue of Fees (Gebührenverzeichnisse). Available from: http:// www.kzbv.de/gebuehrenverzeichnisse.334.de.html, 2013 (accessed 18.07.13).

32] IQWiG, Appraisal of recommendations by the scientific board of IQWiC regarding methods to assess cost-effectiveness in German Public Health Insurance (Wurdigung der Empfehlung des Wissenschaftlichen Beirats des IQWiG zur Methodik für die Bewertung von Verhältnissen zwischen Nutzen und Kosten im System der deutschen gesetzlichen Krankenversicherung). und Kosten im System der deutschen gesetzlichen

Available from: https://www.iqwig.de/download/
Wuerdigung_der_Stellungnahmen_KNB-Methodenentwurf_2.0.pdf, 2009 (accessed 18.07.13).

[33] M. Pennington, P. Heasman, F. Gaunt, A. Guntsch, S. Ivanovski, S. Imazato, S. Rajapakse, E. Allen, T. Flemmig, M. Sanz, C. Vernazza, The cost-effectiveness of supportive periodontal care: a global perspective, J. Clin. Periodontol. 38 (6) (2011) 553-561.

[34] Statistisches Bundesamt, Mortality table 2009/2011 (Sterbetafel 2009/11) Available from: https://www.destatis.de/DE/, 2013 (accessed 17.07.13).

[35] A.H. Briggs, B.J. O'Brien, G. Blackhouse, Thinking outside the box: recent advances in the analysis and presentation of uncertainty in cost-effectiveness studies, Annu. Rev. Public Health 23 (1) (2002) 377-401.

[36] M.F. Drummond, M.J. Sculpher, G.W. Torrance, B.J. O'Brien, G.L. Stoddart, Methods for Economic Evaluation of Health Care Programmes, third ed., Oxford University Press, Oxford, 2005.

[37] S.E. Kopperud, F. Staxrud, I. Espelid, A.B. Tveit, The post-amalgam era: Norwegian dentists' experiences with composite resins and repair of defective amalgam restorations, Int. J. Environ. Res. Public Health 13 (4) (2016).

[38] A.M. Kielbassa, C.D. Lynch, N.H. Wilson, Editorial: the Minamata convention: the beginning of the (amalgam-free) future? Quintessence Int. 45 (7) (2014) 547-548.

[39] F.H. van de Sande, N.J. Opdam, P.A. Rodolpho, M.B. Correa, F.F. Demarco, M.S Cenci, Patient risk factors' influence on survival of posterior composites, J. Dent. Res. 92 (Suppl. 7) (2013) 78S-83S.

[40] F.F. Demarco, M.B. Corrêa, M.S. Cenci, R.R. Moraes, N.J. Opdam, Longevity of posterior composite restorations: not only a matter of materials, Dent. Mater. 28 (1) (2012) 87-101.

[41] D. Ricucci, J. Russo, M. Rutberg, J.A. Burleson, L.S. Spångberg, A prospective cohort study of endodontic treatments of 1369 root canals: results after 5 years, Oral Surg. Oral Med. Oral Pathol. Oral Radiol. Endod. 112 (6) (2011) 825 842

[42] F.J. Burke, P.S. Lucarotti, Ten-year outcome of crowns placed within the general dental services in England and Wales, J. Dent. 37 (1) (2009) 12-24.

[43] Y.L. Ng, V. Mann, K. Gulabivala, Outcome of secondary root canal treatment: a systematic review of the literature, Int. Endod. J. 41 (12) (2008) 1026-1046.

[44] M. Torabinejad, R. Corr, R. Handysides, S. Shabahang, Outcomes of nonsurgical retreatment and endodontic surgery: a systematic review, J. Endod. 35 (7) (2009) 930-937.

[45] R.E. Jung, A. Zembic, B.E. Pjetursson, M. Zwahlen, D.S. Thoma, Systematic review of the survival rate and the incidence of biological, technical, and aesthetic complications of single crowns on implants reported in longitudina studies with a mean follow-up of 5 years, Clin. Oral Implants Res. 23 (Suppl. 6) (2012) 2-21. 


\title{
Repair Surface Conditioning Measures Affect Enamel and Dentin Bond Strength
}

\author{
$\mathrm{P}$ Kanzow $\bullet \mathrm{L}$ Piecha $\bullet \mathrm{J}$ Biermann $\bullet$ A Wiegand
}

\section{Clinical Relevance}

Contamination of enamel and dentin with repair surface conditioning measures should be avoided.

\section{SUMMARY}

Objectives: To analyze whether the contamination with different repair conditioning measures impairs the adhesive performance of a universal adhesive applied in etch-and-rinse mode (ER) or self-etch mode (SE).

Methods and Materials: Bovine enamel and dentin surfaces (each subgroup $n=16$ ) were bonded with a universal adhesive in ER or SE after contamination with different repair conditioning measures (sandblasting, silica coating, hydrofluoric acid etching, self-etching

*Philipp Kanzow, MSc, Dr med dent, Dr rer medic, Department of Preventive Dentistry, Periodontology and Cariology, University Medical Center Göttingen, Göttingen, Germany

Lisa Piecha, Department of Preventive Dentistry, Periodontology and Cariology, University Medical Center Göttingen, Göttingen, Germany

Jana Biermann, Dr med dent, Department of Preventive Dentistry, Periodontology and Cariology, University Medical Center Göttingen, Göttingen, Germany

Annette Wiegand, Prof Dr med dent, Department of Preventive Dentistry, Periodontology and Cariology, University of Göttingen, Göttingen, Germany

*Corresponding author: Robert-Koch-Strasse 40, 37075 Göttingen, Germany; e-mail: philipp.kanzow@med. uni-goettingen.de

https://doi.org/10.2341/19-270-L ceramic primer). In half of the groups, sandblasting, silica coating, and hydrofluoric acid etching was followed by the use of a universal primer. If the universal adhesive was applied in ER, contamination was performed either before or after phosphoric acid etching. If the universal adhesive was applied in SE, bonding was performed after contamination. In the control groups, no contamination was simulated. Shear bond strength (SBS) and failure modes of composite buildups were determined after thermal cycling $\left(10,000\right.$ cycles, $\left.5^{\circ} \mathrm{C}-55^{\circ} \mathrm{C}\right)$. Statistical analysis was performed using analyses of variance, Weibull statistics, and $\chi^{2}$ tests $(\boldsymbol{p}<\mathbf{0 . 0 5})$.

Results: In ER, sandblasting and silica coating significantly reduced SBS (control: enamel = 25.7 $\pm 4.2 \mathrm{MPa}$; dentin $=22.0 \pm 5.3 \mathrm{MPa})$ only when performed after phosphoric acid etching. Contamination with hydrofluoric acid impaired SBS on enamel but not on dentin. The self-etching ceramic primer reduced SBS, but not significantly. The contamination with the universal primer had no significant effect. In SE, all repair conditioning measures except the universal primer reduced SBS (control: enamel $=20.3 \pm 5.5 \mathrm{MPa}$; dentin $=23.0 \pm 4.0$ MPa). 
Conclusion: Contamination of enamel and dentin by repair conditioning measures potentially affects bond strength.

\section{INTRODUCTION}

Repair of partially defective dental restorations is becoming increasingly accepted by dentists and patients as it comes along with substantial advantages compared with complete replacement, for example, preservation of tooth structure, fewer pulpal complications, and reduced treatment time and costs. ${ }^{1}$

Optimal adhesion between the repair material (in most cases composite) and the original restoration makes complex conditioning of the repair surface necessary. Depending on the kind of restorative material, pretreatment of the repair surface to adhere to composite includes mechanical roughening, silica coating, sandblasting (composite, metal, zirconia), or hydrofluoric acid etching (glass ceramic), followed by the use of primers and adhesives containing silane/10-methacryloyloxydecyl dihydrogen phosphate (10-MDP). ${ }^{2,3}$ However, in many clinical situations, the defective part of the restoration is surrounded by dental hard tissue, which makes the additional conditioning of enamel and/or dentin necessary. Especially in small cavities, contamination of enamel or dentin by repair conditioning measures is often unavoidable and might affect adhesion of composite to these dental hard tissues.

Several studies have shown that hydrofluoric acid application on dentin creates an amorphous layer of fluoride, rendering it difficult for adhesives to penetrate. ${ }^{4-7}$ Moreover, as hydrofluoric acid contamination also has the potential to cause chemical burn of surrounding soft tissues, alternative conditioning methods for intraoral repair of glass ceramic restorations are necessary. Recently, a self-etching glass ceramic primer containing ammonium polyfluoride and silane methacrylate was introduced to the market to replace conditioning with hydrofluoric acid and silanization. Although this product is not yet approved for intraoral use, it may be of interest if possible hazardous effects on hard and soft tissues can be avoided. So far, bonding performance of selfetching ceramic primer on lithium disilicate and feldspathic ceramics was shown to be limited compared with hydrofluoric acid etching. ${ }^{8,9}$ Nevertheless, bonding performance might still be acceptable for repaired restorations, especially if possible side effects are reduced. However, no information on contamination effects of the self-etching glass ceramic primer on dental hard tissues is so far available.
Besides hydrofluoric acid etching, potential side effects of silica coating and aluminum oxide sandblasting were investigated but showed conflicting results, depending on the substrate (enamel or dentin) and kind of abrasion particle. ${ }^{10,11}$

However, potential detrimental effects of different repair conditioning measures and sequences have not been systematically analyzed, especially with regard to the bond strength of etch-and-rinse or selfetch adhesives. Therefore, in this study we aimed to analyze the shear bond strength of a universal adhesive applied in etch-and-rinse mode (ER) or self-etch mode (SE) on enamel and dentin after contamination with different repair surface conditioning measures and sequences. The null hypothesis tested was that the bond strength of the universal adhesive is not affected by the various repair conditioning measures.

\section{METHODS AND MATERIALS}

\section{Specimen Preparation}

Cylindrical enamel and dentin specimens $(5.7 \mathrm{~mm}$ in diameter) were prepared from the crowns or roots of freshly extracted, nondamaged bovine incisors. The specimens were then embedded in chemically cured acrylic resin (Paladur, Kulzer, Hanau, Germany) and ground flat using sandpaper (WS flex 18C, grits 500 und 800, Hermes, Hamburg, Germany) while being water-cooled (RotoPol-35 and PdM-Force-20, Struers, Willich, Germany). Specimens were randomly divided into 25 groups of enamel or dentin specimens $(\mathrm{n}=16$ for shear bond strength analysis, $\mathrm{n}=2$ for scanning electron microscopy [SEM] analysis).

\section{Simulated Contamination and Bonding Procedures}

The composition of the universal adhesive and the materials used in this study is presented in Table 1; surface contamination measures/sequences are shown in Tables 2 through 5.

The universal adhesive (Adhese Universal, Ivoclar Vivadent, Schaan, Liechtenstein) was either applied in ER (groups 1-16) or SE (groups 17-25) on enamel and dentin specimens.

If used in ER, 37\% phosphoric acid was applied for 30 seconds (enamel) or 15 seconds (dentin) to the surface, rinsed with water for 30 seconds or 15 seconds (respectively) and gently air-dried. In the control group (group 1), the adhesive was applied without any simulated contamination and light-cured (20 seconds, B.A. Optima 10 LED, B.A. International, Hamburg, Germany). Contamination by sandblast- 
Kanzow \& Others: Repair Measures Affect Bond Strength

\begin{tabular}{|c|c|c|c|c|}
\hline Product & Manufacturer & Lot No & Composition & Application Mode \\
\hline Adhese Universal & $\begin{array}{l}\text { Ivoclar Vivadent, } \\
\text { Schaan, Liechtenstein }\end{array}$ & $\begin{array}{l}\text { W91987, } \\
\text { X38352 }\end{array}$ & $\begin{array}{l}\text { HEMA }(10 \%-25 \%) \text {, Bis-GMA ( } 10 \%-25 \%) \text {, } \\
\text { ethanol }(10 \%-25 \%), 1,10 \text {-decandiol } \\
\text { dimethacrylate }(\geq 2.5 \%-<10 \%) \text {, methacrylated } \\
\text { phosphoric acid ester }(\geq 2.5 \%-<10 \%) \text {, } \\
\text { campherquinone }(1 \%-<2.5 \%) \text {, DMAEMA } \\
(\geq 1 \%-<2.5 \%)\end{array}$ & $\begin{array}{l}20 \mathrm{~s} \text { (scrubbing into the tooth } \\
\text { surface using a disposable } \\
\text { microbrush), } 20 \mathrm{~s} \text { light-curing }\end{array}$ \\
\hline Filtek Supreme XTE & $\begin{array}{l}\text { 3M ESPE, Seefeld, } \\
\text { Germany }\end{array}$ & N779140 & $\begin{array}{l}\text { Silane treated ceramic }(60 \%-80 \%) \text {, silane } \\
\text { treated silica }(1 \%-10 \%) \text {, UDMA }(1 \%-10 \%) \text {, } \\
\text { bisphenol A polyethylene glycol diether } \\
\text { dimethacrylate }(1 \%-10 \%) \text {, Bis-GMA }(1 \%-10 \%) \text {, } \\
\text { silane treated zirconia }(1 \%-5 \%) \text {, polyethylene } \\
\text { glycol dimethacrylate }(<5 \%) \text {, triethylene glycol } \\
\text { dimethacrylate }(<1 \%)\end{array}$ & $\begin{array}{l}\text { 2-mm-thick increments, each } 20 \\
\text { s light-cured }\end{array}$ \\
\hline $\begin{array}{l}\text { CoJet sand (silica- } \\
\text { coated aluminum } \\
\text { oxide) }\end{array}$ & $\begin{array}{l}\text { 3M ESPE, Seefeld, } \\
\text { Germany }\end{array}$ & $\begin{array}{l}630975 \\
4236465\end{array}$ & $\begin{array}{l}\text { Aluminum oxide }(>95 \%) \text {, synthetic amorphous } \\
\text { silica }(<5 \%)\end{array}$ & $\begin{array}{l}4 \mathrm{~s}, 10-\mathrm{mm} \text { distance, } 45^{\circ}, 2-3 \mathrm{bar} \\
\text { air pressure }\end{array}$ \\
\hline $\begin{array}{l}\text { Super Etch (phosphoric } \\
\text { acid gel) }\end{array}$ & $\begin{array}{l}\text { SDI, Bayswater, } \\
\text { Australia }\end{array}$ & 171138 & Phosphoric acid (37\%) & $\begin{array}{l}30 \mathrm{~s} \text { (enamel) or } 15 \mathrm{~s} \text { (dentin), } 30 \\
\mathrm{~s} \text { or } 15 \mathrm{~s} \text { (respectively) water- } \\
\text { rinsing, gentle air-drying }\end{array}$ \\
\hline $\begin{array}{l}\text { Airsonic Alu-Oxyd } \\
\text { (aluminum oxide) } \\
\end{array}$ & $\begin{array}{l}\text { Hager \& Werken, } \\
\text { Duisburg, Germany }\end{array}$ & $\mathrm{N} / \mathrm{A}$ & $\mathrm{N} / \mathrm{A}$ & $\begin{array}{l}4 \mathrm{~s}, 10-\mathrm{mm} \text { distance, } 45^{\circ}, 2-3 \mathrm{bar} \\
\text { air pressure }\end{array}$ \\
\hline $\begin{array}{l}\text { Porcelain Etch ( } 9 \% \\
\text { buffered hydrofluoric } \\
\text { acid gel) }\end{array}$ & $\begin{array}{l}\text { Ultradent Products, } \\
\text { Cologne, Germany }\end{array}$ & BFTKV & Hydrofluoric acid $(<10 \%)$ & $90 \mathrm{~s}$, water-rinsing (15 s) \\
\hline Monobond Etch\&Prime & $\begin{array}{l}\text { Ivoclar Vivadent, } \\
\text { Schaan, Liechtenstein }\end{array}$ & X30890 & $\begin{array}{l}\text { Butanol }(20 \%-<25 \%) \text {, tetrybutylammonium } \\
\text { dihydrogen trifluoride }(\leq 10 \%) \text {, methacrylated } \\
\text { phosphoric acid ester }(2.5 \%-<10 \%) \text {, } \\
\text { bis(triethoxysilyl)ethane }(1 \%-<2.5 \%)\end{array}$ & $\begin{array}{l}20 \mathrm{~s} \text {, after } 40 \mathrm{~s} \text { water-rinsing (15 } \\
\mathrm{s}) \text {, gentle air-drying }\end{array}$ \\
\hline Monobond Plus & $\begin{array}{l}\text { Ivoclar Vivadent, } \\
\text { Schaan, Liechtenstein }\end{array}$ & X11257 & $\begin{array}{l}\text { Ethanol }(50 \%-100 \%) \text {, methacrylated } \\
\text { phosphoric acid ester }(1 \%-<2.5 \%)\end{array}$ & $20 \mathrm{~s}$ gentle air-blowing after $60 \mathrm{~s}$ \\
\hline
\end{tabular}

ing, silica coating, hydrofluoric acid etching, or the self-etching ceramic primer was performed either before (groups 10-16) or after (groups 3-9) phosphoric acid etching. In half of the groups, surfaces were also exposed to a universal primer.

If used in SE, the adhesive was applied for 20 seconds (enamel and dentin) before light-curing for 20 seconds (B.A. Optima 10 LED): In the respective control group (group 17), no contamination of the surfaces was performed. In the test groups, sandblasting, silica coating, hydrofluoric acid etching, or the application of the self-etching primer was performed before the adhesive was applied. In half of the specimens in each group, surfaces were also contaminated with a universal primer.

The following surface contamination measures were applied either alone or in combination:

1) Air-abrasion with aluminum oxide $(50 \mu \mathrm{m}$; Hager \& Werken, Duisburg, Germany) for 4 seconds at a distance of $10 \mathrm{~mm}\left(45^{\circ}\right)$ and 2-3 bar air pressure. Remnants were air blown.
2) Silica coating: Surfaces were silica coated (30 $\mu \mathrm{m}$; CoJet, 3M ESPE, Seefeld, Germany) for 4 seconds at a distance of $10 \mathrm{~mm}\left(45^{\circ}\right)$ and 2-3 bar air pressure. Loose particles were air blown.

3) Hydrofluoric acid (9\% buffered hydrofluoric acid gel; Porcelain Etch, Ultradent Products, Cologne, Germany) was applied for 90 seconds. Samples were subsequently rinsed with water for 60 seconds.

4) The self-etching ceramic primer (Monobond Etch\&Prime, Ivoclar Vivadent) was applied with a microbrush for 20 seconds followed by a 40 second contact time. Specimens were subsequently rinsed with water for 15 seconds.

5) Universal primer (Monobond Plus, Ivoclar Vivadent) was applied using a microbrush and allowed to evaporate for 60 seconds as recommended by the manufacturer. Afterward, samples were gently air blown.

After the universal adhesive was applied, the repair composite (Filtek Supreme XTE, 3M ESPE; shade A2) was adhered onto the specimen surface 
using acrylic hollow cylinders (inner diameter: 3 $\mathrm{mm}$, height: $4 \mathrm{~mm}$ ). The composite was packed against the surface in a 2-mm-thick increment and light-cured for 20 seconds by applying the curing unit directly onto the acrylic cylinder. Light irradiance $\left(>800 \mathrm{~mW} / \mathrm{cm}^{2}\right)$ was verified every 30 specimens using a radiometer (Cure Rite Model 644726, Dentsply Caulk, Milford, DE, USA). Contamination and bonding procedures were carried out by one operator (LP) throughout all experiments.

All specimens were then submitted to a thermal cycling procedure $\left(10,000\right.$ cycles, between $5^{\circ} \mathrm{C}$ and $55^{\circ} \mathrm{C}$, dwell time: 20 seconds, transfer time: 10 seconds) before shear bond testing.

\section{Shear Bond Measurements and Failure Analysis}

Shear bond strength was tested with a universal testing machine (Materialprüfmaschine 1446, Zwick, Ulm, Germany). A shear force was applied to the adhesive interface through a chisel-shaped loading device at a crosshead speed of $1 \mathrm{~mm} / \mathrm{min}$ parallel to the surface of the specimens. Load at fracture was recorded, and shear bond strength $(\sigma)$ was calculated by software (TestXpert 11.02, Zwick) using the load at failure $F(\mathrm{~N})$ and the adhesive area $A\left(\mathrm{~mm}^{2}\right): \sigma=F / A$.

The debonded area was examined for failure mode analysis with a stereomicroscope at $16 \times$ magnification (Stemi SV 11, Zeiss, Oberkochen, Germany). Failure mode was considered as adhesive if it occurred at the interface; as cohesive if at least parts of either enamel, dentin, or composite were affected; or as mixed when both adhesive and cohesive failures occurred.

\section{SEM Analysis}

Two specimens of each group were desiccated for 2 weeks in silica gel, sputter-coated with carbon, and analyzed by SEM (Ultra plus FE-SEM, Zeiss) at 10 $\mathrm{kV}$.

\section{Statistical Analysis}

Statistical analyses were performed using the software SPSS Statistics for Macintosh (version 25.0.0.1, IBM, Armonk, NY, USA).

Separately for enamel and dentin, three-way analysis of variance (ANOVA) (ER without groups 9 and 16) and two-way ANOVA (SE without group 25) were performed. Factors were the sequence in which phosphoric acid etching was performed (first or second step, only in ER), the kind of contamination (sandblasting, silica coating, hydrofluoric acid etching, control), and the use of a universal primer. Moreover, one-way ANOVAs followed by Scheffe post hoc tests were applied to compare all groups, including those where the self-etching ceramic primer was used.

Additionally, characteristic bond strength $\sigma_{0}$ and Weibull modulus $m$ (Weibull distribution parameters) were assessed using the maximum likelihood estimates and 95\% confidence intervals in MATLAB (version R2018b, 9.5.0.1049112, The MathWorks, Natick, MA, USA).

For both substrates and each adhesive mode, effects of different repair surface treatments on failure modes were analyzed using $\chi^{2}$ tests adjusted according to Bonferroni. The overall level of significance was set at $\alpha=0.05$.

\section{RESULTS}

When the universal adhesive was applied in ER, shear bond strength values in enamel were significantly affected by the sequence of phosphoric acid etching $(p<0.001$, after contamination $>$ before contamination) and the kind of contamination $(p<0.001$, control $>$ sandblasting $=$ silica coating $>$ hydrofluoric acid) but not by the contamination with the universal primer $(p=0.056)$. The interaction between factors was not significant $(p>0.169)$, except for the interaction between "sequence of phosphoric acid etching" and "kind of contamination" $(p<0.001)$. Between-group comparisons showed that groups $3-8,14$, and 15 led to significantly lower bond strength than the control. Shear bond strength, Weibull parameters, and failure modes of enamel specimens conditioned with the universal adhesive in ER are presented in Table 2.

If applied in SE, shear bond strength values on enamel were significantly affected by the kind of contamination $(p<0.001$, control $>$ sandblasting $=$ silica coating $>$ hydrofluoric acid) and by the use of a universal primer $(p=0.028)$. The interaction between factors was not significant $(p=0.389)$. Betweengroup comparisons showed that all repair contamination measures (except application of the universal primer, group 2) led to significantly reduced bond strength values. Shear bond strength, Weibull parameters, and failure modes of enamel specimens conditioned with the universal adhesive in SE are presented in Table 3.

On dentin, the shear bond strength of the universal adhesive applied in ER was significantly affected by the sequence of phosphoric acid etching $(p<0.001$, after contamination $>$ before contamina- 
Kanzow \& Others: Repair Measures Affect Bond Strength

\begin{tabular}{|c|c|c|c|c|c|c|c|c|c|c|}
\hline \multirow[t]{2}{*}{ Group } & \multicolumn{4}{|c|}{ Surface Contamination/Conditioning } & \multirow{2}{*}{$\begin{array}{c}\text { Bond Strength } \\
\text { (MPa) } \\
\text { Mean } \pm \text { SD }\end{array}$} & \multicolumn{2}{|c|}{ Weibull Parameters $[95 \% \mathrm{Cl}]$} & \multicolumn{3}{|c|}{ Failure Mode (\%) } \\
\hline & 1. Step & 2. Step & 3. Step & 4. Step & & $\sigma_{0}(\mathrm{MPa})$ & $m$ & Adhesive & Mixed & Cohesive \\
\hline 1 & \multirow{9}{*}{$\begin{array}{l}\text { Phosphoric } \\
\text { acid }\end{array}$} & \multirow[t]{2}{*}{ None } & - (Control) & \multirow{16}{*}{$\begin{array}{l}\text { Universal } \\
\text { adhesive }\end{array}$} & $25.7 \pm 4.2 \mathrm{EF}$ & $27.4[25.5,29.5]$ & $7.2[4.9,10.7]$ & 6.7 & 93.3 & 0.0 \\
\hline 2 & & & Universal primer & & $27.3 \pm 3.6 \mathrm{~F}$ & $28.6[27.4,29.9]$ & $11.6[7.8,17.3]$ & 37.5 & 50.0 & 12.5 \\
\hline 3 & & \multirow[t]{2}{*}{ Sandblasting } & - & & $15.8 \pm 4.3 \mathrm{ABC}$ & $17.4[15.3,19.8]$ & $4.0[2.8,5.8]$ & 75.0 & 25.0 & 0.0 \\
\hline 4 & & & Universal primer & & $16.0 \pm 1.7 \mathrm{ABC}$ & $16.8[15.9,17.6]$ & $10.5[7.2,15.2]$ & 56.3 & 43.8 & 0.0 \\
\hline 5 & & \multirow[t]{2}{*}{ Silica coating } & - & & $11.3 \pm 3.6 \mathrm{~A}$ & $12.5[10.8,14.6]$ & $3.4[2.4 ; 4.9]$ & 50.0 & 50.0 & 0.0 \\
\hline 6 & & & Universal primer & & $12.6 \pm 2.3 \mathrm{~A}$ & $13.6[12.5,14.7]$ & $6.4[4.3,9.4]$ & 31.3 & 68.8 & 0.0 \\
\hline 7 & & \multirow{2}{*}{$\begin{array}{l}\text { Hydrofluoric } \\
\text { acid }\end{array}$} & - & & $13.9 \pm 5.6 \mathrm{AB}$ & $15.6[13.0,18.7]$ & $2.8[1.9,4.2]$ & 25.0 & 68.8 & 6.3 \\
\hline 8 & & & Universal primer & & $14.3 \pm 4.4 \mathrm{AB}$ & $15.9[14.0,18.1]$ & $4.0[2.6,6.0]$ & 25.0 & 75.0 & 0.0 \\
\hline 9 & & \multicolumn{2}{|c|}{ Self-etching ceramic primer } & & $21.6 \pm 4.1 \mathrm{BCDEF}$ & $23.1[21.5,24.9]$ & $6.8[4.6,10.2]$ & 50.0 & 50.0 & 0.0 \\
\hline 10 & \multirow[t]{2}{*}{ Sandblasting } & \multirow[t]{7}{*}{ Phosphoric acid } & - & & $23.8 \pm 4.4 \mathrm{CDEF}$ & $25.4[23.8,27.0]$ & $8.2[5.4,12.5]$ & 43.8 & 43.8 & 12.5 \\
\hline 11 & & & Universal primer & & $23.9 \pm 5.7 \mathrm{CDEF}$ & $25.6[23.5,27.9]$ & $5.9[3.9,8.9]$ & 50.0 & 50.0 & 0.0 \\
\hline 12 & \multirow[t]{2}{*}{ Silica coating } & & - & & $24.8 \pm 3.9 \mathrm{EF}$ & $26.4[24.7,28.2]$ & $7.8[5.3,11.4]$ & 0.0 & 92.9 & 7.1 \\
\hline 13 & & & Universal primer & & $24.5 \pm 3.7 \mathrm{DEF}$ & $26.2[24.2,28.2]$ & $6.8[4.8,9.7]$ & 12.5 & 87.5 & 0.0 \\
\hline 14 & \multirow{2}{*}{$\begin{array}{l}\text { Hydrofluoric } \\
\text { acid }\end{array}$} & & - & & $12.0 \pm 5.5 \mathrm{~A}$ & $13.6[11.0,16.7]$ & $2.5[1.6,3.7]$ & 37.5 & 62.5 & 0.0 \\
\hline 15 & & & Universal primer & & $16.5 \pm 6.1 \mathrm{ABCD}$ & $18.5[15.7,21.6]$ & $3.2[2.1,4.9]$ & 25.0 & 68.8 & 6.3 \\
\hline 16 & $\begin{array}{l}\text { Self-etching } \\
\text { ceramic primer }\end{array}$ & & - & & $18.9 \pm 6.4 \mathrm{ABCDE}$ & $20.9[18.2,23.9]$ & $3.7[2.4,5.8]$ & 46.7 & 46.7 & 6.7 \\
\hline
\end{tabular}

tion) and the kind of contamination $(p<0.001$, control $=$ hydrofluoric acid $>$ sandblasting $>$ silica coating) but not by the contamination with the universal primer $(p=0.923)$. The interactions between factors were significant $(p<0.043)$, except for the interaction between "sequence of phosphoric acid etching" and "kind of contamination" $(p=0.268)$. Between-group comparisons revealed that bond strength was significantly reduced in groups 3-6 and 13 compared with the respective control. Shear bond strength, Weibull parameters, and failure modes of enamel specimens conditioned with the universal adhesive in ER are presented in Table 4.
If applied in SE, shear bond strength was affected by the kind of contamination $(p<0.001$, control $>$ hydrofluoric acid $>$ sandblasting $>$ silica coating) and the use of the universal primer $(p=0.001)$; the interaction between factors was not significant $(p=0.210)$. Between-group comparisons showed that all contamination measures, except for the universal primer (group 18) and hydrofluoric acid/universal primer (group 24), led to significantly reduced bond strength. Shear bond strength, Weibull parameters, and failure modes of enamel specimens conditioned with the universal adhesive in SE are presented in Table 5.

\begin{tabular}{|c|c|c|c|c|c|c|c|c|c|}
\hline \multirow[t]{2}{*}{ Group } & \multicolumn{3}{|c|}{ Surface Contamination/Conditioning } & \multirow{2}{*}{$\begin{array}{c}\text { Bond Strength } \\
(\mathrm{MPa}) \\
\text { Mean } \pm \text { SD }\end{array}$} & \multicolumn{2}{|c|}{ Weibull Parameters $[95 \% \mathrm{Cl}]$} & \multicolumn{3}{|c|}{ Failure Mode (\%) } \\
\hline & 1. Step & 2. Step & 3. Step & & $\sigma_{0}(\mathrm{MPa})$ & $m$ & Adhesive & Mixed & Cohesive \\
\hline 17 & \multirow[t]{2}{*}{ None } & - (Control) & \multirow{9}{*}{$\begin{array}{l}\text { Universal } \\
\text { adhesive }\end{array}$} & $20.3 \pm 5.5 c$ & $22.3[19.9,24.9]$ & $4.5[3.1,6.7]$ & 31.3 & 43.8 & 25.0 \\
\hline 18 & & Universal primer & & $23.7 \pm 4.3 \mathrm{c}$ & $25.3[23.6,27.2]$ & $7.3[4.9,10.9]$ & 37.5 & 43.8 & 18.8 \\
\hline 19 & \multirow[t]{2}{*}{ Sandblasting } & - & & $11.4 \pm 5.3 \mathrm{~B}$ & $12.8[10.3,15.9]$ & $2.4[1.6,3.5]$ & 73.3 & 26.7 & 0.0 \\
\hline 20 & & Universal primer & & $13.6 \pm 3.9 \mathrm{~B}$ & $14.9[13.1,16.9]$ & $4.1[2.8,6.0]$ & 60.0 & 40.0 & 0.0 \\
\hline 21 & \multirow[t]{2}{*}{ Silica coating } & - & & $12.8 \pm 3.8$ в & $14.1[12.6,15.8]$ & $4.5[2.9,7.0]$ & 64.3 & 35.7 & 0.0 \\
\hline 22 & & Universal primer & & $13.8 \pm 3.4 \mathrm{~B}$ & $15.1[13.6,16.7]$ & $4.9[3.3,7.3]$ & 80.0 & 20.0 & 0.0 \\
\hline 23 & \multirow[t]{2}{*}{ Hydrofluoric acid } & - & & $2.3 \pm 2.9 \mathrm{~A}$ & $2.1[1.2,3.8]$ & $0.9[0.6,1.3]$ & 68.8 & 31.3 & 0.0 \\
\hline 24 & & Universal primer & & $2.3 \pm 3.3 \mathrm{~A}$ & $1.6[0.6,3.9]$ & $0.5[0.4,0.8]$ & 87.5 & 12.5 & 0.0 \\
\hline 25 & \multicolumn{2}{|c|}{ Self-etching ceramic primer } & & $2.3 \pm 2.2 \mathrm{~A}$ & $1.6[0.5,5.2]$ & $0.4[0.3,0.7]$ & 100.0 & 0.0 & 0.0 \\
\hline
\end{tabular}




\begin{tabular}{|c|c|c|c|c|c|c|c|c|c|c|}
\hline \multirow[t]{2}{*}{ Group } & \multicolumn{4}{|c|}{ Surface Contamination/Conditioning } & \multirow{2}{*}{$\begin{array}{c}\text { Bond Strength } \\
(\mathrm{MPa}) \\
\text { Mean } \pm \text { SD }\end{array}$} & \multicolumn{2}{|c|}{ Weibull Parameters $[95 \% \mathrm{Cl}]$} & \multicolumn{3}{|c|}{ Failure Mode (\%) } \\
\hline & 1. Step & 2. Step & 3. Step & 4. Step & & $\sigma_{0}(\mathrm{MPa})$ & $m$ & Adhesive & Mixed & Cohesive \\
\hline 1 & \multirow{2}{*}{$\begin{array}{l}\text { Phosphoric } \\
\text { acid }\end{array}$} & \multirow[t]{2}{*}{ None } & - (Control) & \multirow{16}{*}{$\begin{array}{l}\text { Universal } \\
\text { adhesive }\end{array}$} & $22.0 \pm 5.3 \mathrm{E}$ & $24.0[21.7,26.6]$ & $5.0[3.4,7.5]$ & 53.3 & 46.7 & 0.0 \\
\hline 2 & & & $\begin{array}{l}\text { Universal } \\
\text { primer }\end{array}$ & & $21.2 \pm 3.8 \mathrm{E}$ & $22.7[21.1,24.4]$ & $7.1[4.8,10.5]$ & 25.0 & 75.0 & 0.0 \\
\hline 3 & & \multirow[t]{2}{*}{ Sandblasting } & - & & $12.3 \pm 4.6 \mathrm{ABC}$ & $13.7[11.6,16.2]$ & $3.0[2.0,4.5]$ & 62.5 & 37.5 & 0.0 \\
\hline 4 & & & $\begin{array}{l}\text { Universal } \\
\text { primer }\end{array}$ & & $13.7 \pm 3.2 \mathrm{ABCD}$ & $14.9[13.6,16.3]$ & $5.5[3.7,8.4]$ & 68.8 & 31.3 & 0.0 \\
\hline 5 & & \multirow[t]{2}{*}{ Silica coating } & - & & $9.6 \pm 3.0 \mathrm{AB}$ & $10.6[9.3,12.1]$ & $3.9[2.6,5.8]$ & 68.8 & 31.3 & 0.0 \\
\hline 6 & & & $\begin{array}{l}\text { Universal } \\
\text { primer }\end{array}$ & & $8.7 \pm 3.8 \mathrm{~A}$ & $9.5[7.4,12.1]$ & $2.0[1.3,3.1]$ & 56.3 & 43.8 & 0.0 \\
\hline 7 & & \multirow{2}{*}{$\begin{array}{l}\text { Hydrofluoric } \\
\text { acid }\end{array}$} & - & & $15.6 \pm 5.3 \mathrm{ABCDE}$ & $17.0[14.6,19.8]$ & $3.3[2.1,5.0]$ & 43.8 & 56.3 & 0.0 \\
\hline 8 & & & $\begin{array}{l}\text { Universal } \\
\text { primer }\end{array}$ & & $22.4 \pm 1.8 \mathrm{E}$ & $23.1[22.4,23.9]$ & $15.9[10.8,23.6]$ & 31.3 & 68.8 & 0.0 \\
\hline 9 & & \multicolumn{2}{|l|}{$\begin{array}{l}\text { Self-etching } \\
\text { ceramic primer }\end{array}$} & & $20.5 \pm 2.3 \mathrm{DE}$ & $21.5[20.5,22.5]$ & $11.0[7.5,16.0]$ & 43.8 & 56.3 & 0.0 \\
\hline 10 & \multirow[t]{2}{*}{ Sandblasting } & \multirow{4}{*}{$\begin{array}{l}\text { Phosphoric } \\
\text { acid }\end{array}$} & - & & 16.2 $\pm 4.4 \mathrm{BCDE}$ & $17.7[15.9,19.8]$ & $4.7[3.1,7.1]$ & 62.5 & 37.5 & 0.0 \\
\hline 11 & & & $\begin{array}{l}\text { Universal } \\
\text { primer }\end{array}$ & & $17.6 \pm 3.1 \mathrm{CDE}$ & $18.7[17.6,19.8]$ & $8.7[5.8,13.3]$ & 64.3 & 35.7 & 0.0 \\
\hline 12 & \multirow[t]{2}{*}{ Silica coating } & & - & & $17.9 \pm 5.3 \mathrm{CDE}$ & $19.7[17.4,22.4]$ & $4.0[2.7,5.9]$ & 28.6 & 71.4 & 0.0 \\
\hline 13 & & & $\begin{array}{l}\text { Universal } \\
\text { primer }\end{array}$ & & $10.0 \pm 4.2 \mathrm{AB}$ & $11.2[9.2,13.6]$ & $2.7[1.8,4.0]$ & 50.0 & 50.0 & 0.0 \\
\hline 14 & \multirow{2}{*}{$\begin{array}{l}\text { Hydrofluoric } \\
\text { acid }\end{array}$} & & - & & $20.7 \pm 3.2 \mathrm{DE}$ & $22.0[20.6,23.5]$ & $7.7[5.3,11.3]$ & 33.3 & 66.7 & 0.0 \\
\hline 15 & & & $\begin{array}{l}\text { Universal } \\
\text { primer }\end{array}$ & & $22.0 \pm 5.3 \mathrm{E}$ & $23.9[21.7,26.4]$ & $5.2[3.5,7.7]$ & 18.8 & 81.3 & 0.0 \\
\hline 16 & $\begin{array}{l}\text { Self-etching } \\
\text { ceramic primer }\end{array}$ & & - & & $17.6 \pm 4.5 \mathrm{CDE}$ & $19.3[17.2,21.6]$ & $4.5[3.1,6.6]$ & 87.5 & 12.5 & 0.0 \\
\hline
\end{tabular}

Highest Weibull parameters (characteristic strength $\sigma_{0}$ and Weibull modulus $m$ ) were reached in the control groups or when solely the universal primer was applied, irrespective of the adhesive strategy and the substrate. The only exception was found in the ER groups on dentin, where group 8 (phosphoric acid etching followed by hydrofluoric acid and the universal primer) obtained the highest Weibull modulus. For both enamel and dentin in ER, the majority of the groups reached higher charac-

\begin{tabular}{|c|c|c|c|c|c|c|c|c|c|}
\hline \multirow[t]{2}{*}{ Group } & \multicolumn{3}{|c|}{ Surface Contamination/Conditioning } & \multirow{2}{*}{$\begin{array}{c}\text { Bond Strength } \\
\text { (MPa) } \\
\text { Mean } \pm \text { SD }\end{array}$} & \multicolumn{2}{|c|}{ Weibull Parameters [95\% Cl] } & \multicolumn{3}{|c|}{ Failure Mode (\%) } \\
\hline & 1. Step & 2. Step & 3. Step & & $\sigma_{0}(\mathrm{MPa})$ & $m$ & Adhesive & Mixed & Cohesive \\
\hline 17 & \multirow[t]{2}{*}{ None } & $-($ Control) & \multirow{9}{*}{$\begin{array}{l}\text { Universal } \\
\text { adhesive }\end{array}$} & $23.0 \pm 4.0 \mathrm{DE}$ & $24.6[23.0,26.3]$ & $7.6[5.1,11.5]$ & 14.3 & 64.3 & 21.4 \\
\hline 18 & & Universal primer & & $24.9 \pm 4.6 \mathrm{E}$ & $26.7[24.5,29.2]$ & $5.9[4.1,8.3]$ & 0.0 & 28.6 & 71.4 \\
\hline 19 & \multirow[t]{2}{*}{ Sandblasting } & - & & $10.3 \pm 4.6 \mathrm{AB}$ & $10.1[5.8,17.7]$ & $0.9[0.5,1.4]$ & 86.7 & 13.3 & 0.0 \\
\hline 20 & & Universal primer & & $12.3 \pm 2.3 \mathrm{ABC}$ & $13.2[12.1,14.5]$ & $5.7[4.0,8.2]$ & 53.3 & 46.7 & 0.0 \\
\hline 21 & \multirow[t]{2}{*}{ Silica coating } & - & & $7.3 \pm 4.0 \mathrm{~A}$ & $8.2[6.3,10.7]$ & $2.0[1.3,2.9]$ & 85.7 & 14.3 & 0.0 \\
\hline 22 & & Universal primer & & $8.1 \pm 4.9$ АВ & $9.0[6.6,12.3]$ & $1.6[1.1,2.5]$ & 92.3 & 7.7 & 0.0 \\
\hline 23 & \multirow[t]{2}{*}{ Hydrofluoric acid } & - & & $13.1 \pm 5.1 \mathrm{BC}$ & $14.5[12.2,17.2]$ & $2.9[1.9,4.5]$ & 53.3 & 46.7 & 0.0 \\
\hline 24 & & Universal primer & & $18.3 \pm 4.1 \mathrm{CD}$ & $19.9[17.9,22.1]$ & $5.0[3.4,7.2]$ & 46.2 & 53.8 & 0.0 \\
\hline 25 & \multicolumn{2}{|c|}{ Self-etching ceramic primer } & & $9.6 \pm 4.1 \mathrm{AB}$ & $10.8[8.9,13.2]$ & $2.6[1.8,3.8]$ & 100.0 & 0.0 & 0.0 \\
\hline
\end{tabular}




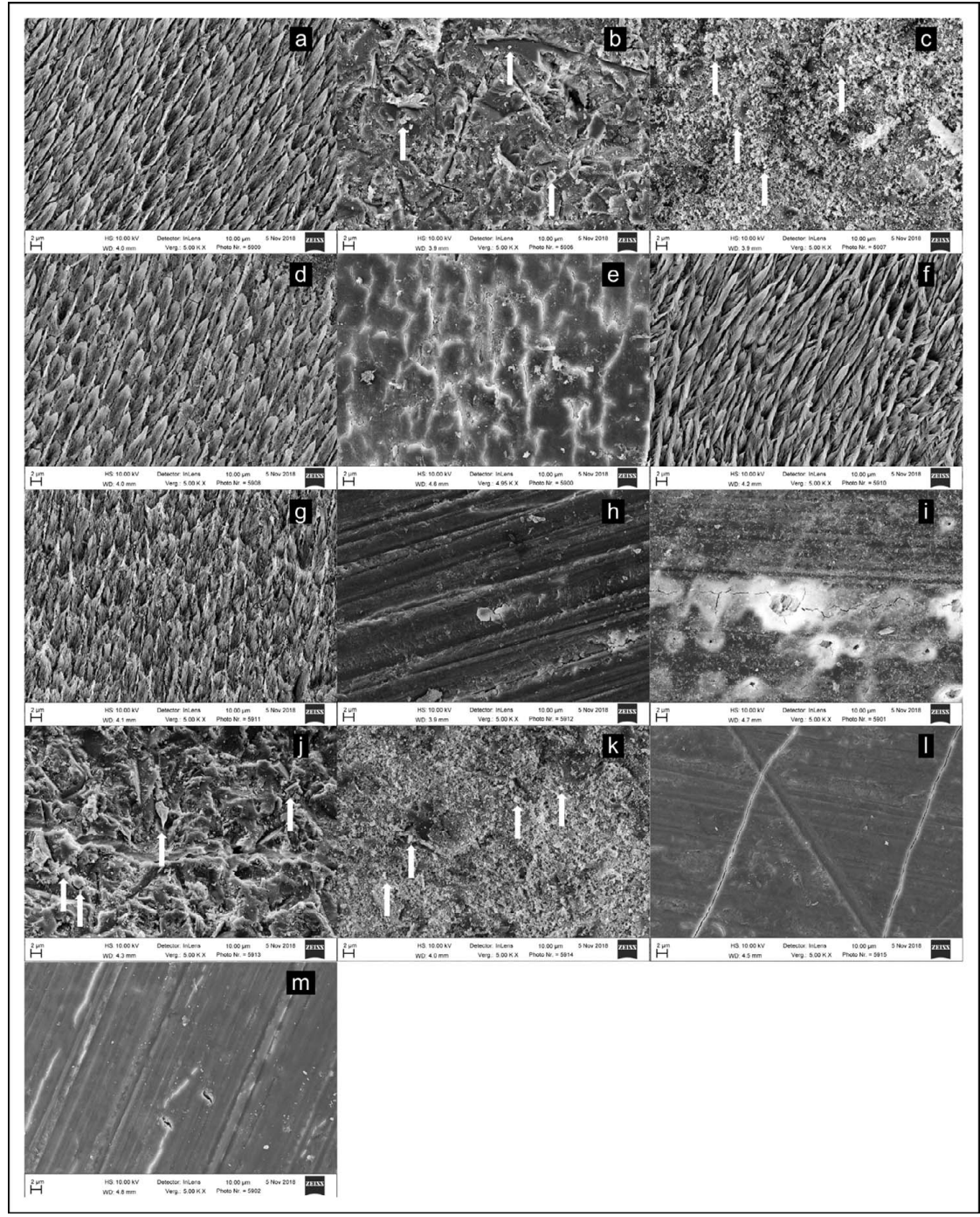

Figure 1. Representative scanning electron micrographs of enamel surfaces treated with sandblasting, silica coating, hydrofluoric acid etching, or the self-etching ceramic primer either alone (contamination before application of the adhesive in self-etch mode) or before/after phosphoric acid etching (contamination before application in etch-and-rinse mode). Note that contamination with the universal primer is not shown as it was not visible. Original magnification $\times 5000$. (a): Phosphoric acid (control etch-andrinse, group 1). (b): Phosphoric acid $\rightarrow$ sandblasting (group 3). (c): Phosphoric acid $\rightarrow$ silica coating (group 5). $(d)$ : Phosphoric acid $\rightarrow$ hydrofluoric acid (group 7). (e): Phosphoric acid $\rightarrow$ self-etching ceramic primer (group 9).

(f): Sandblasting $\rightarrow$ phosphoric acid (group 10). (g): Silica coating $\rightarrow$ phosphoric acid (group 12). (h): Hydrofluoric acid $\rightarrow$ phosphoric acid (group 14). (i): Self-etching ceramic primer $\rightarrow$ phosphoric acid (group 16). (j): Sandblasting (group 19). (k): Silica coating (group 21). (l): Hydrofluoric acid (group 23). ( $m$ ): Self-etching ceramic primer (group 25). Abrasive remnants are marked by $\uparrow$.

teristic bond strengths when contamination was followed by phosphoric acid etching compared with phosphoric acid etching before contamination.

For both substrates and both adhesive application modes, the distribution of failure types differed significantly between different repair contaminations $(p \leq 0.003)$.

\section{SEM Images}

SEM images are presented in Figures 1 (enamel) and 2 (dentin). Contamination of phosphoric acid etched enamel (Figure 1a) with sandblasting (Figure 1b) or silica coating (Figure 1c) resulted in removal of the etching pattern. When phosphoric acid etching was performed after sandblasting (Figure 1f) or silica coating (Figure 1g), the surface presented an etching pattern not different from the control (Figure 1a). If sandblasting or silica coating, respectively, was not followed by phosphoric acid etching (ie, the universal adhesive was applied in SE), then the surface was distinctly roughened and remnants of abrasive particles could be seen (Figure 1j,k).

Hydrofluoric acid contamination of etched enamel resulted in an etching pattern with few visible surface precipitates (Figure 1d), while hydrofluoric acid etching of native enamel resulted in an amorphous surface layer (Figure 1h,l), which could not be removed by phosphoric acid etching (Figure 1h). Surface precipitation was also visible after 


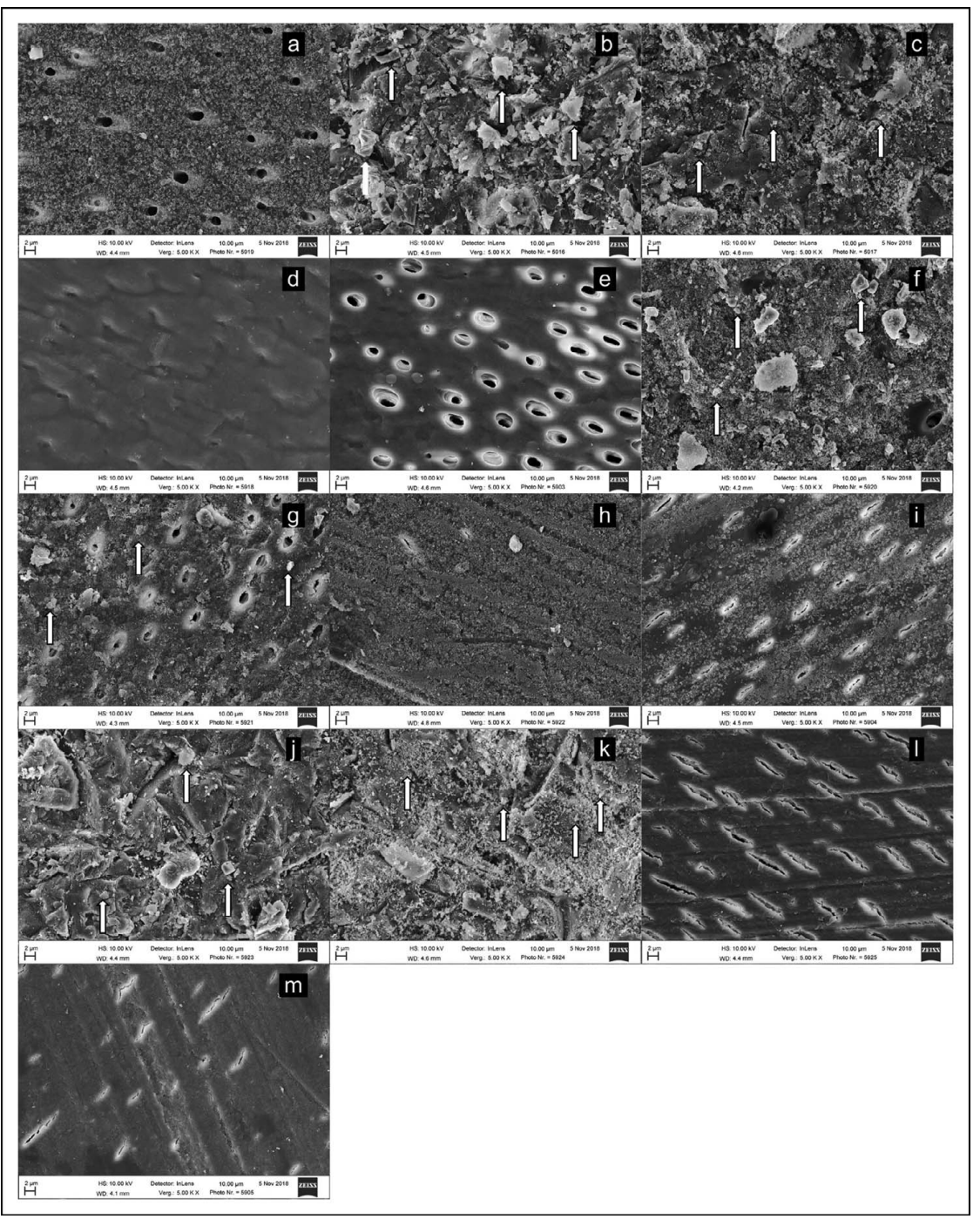

Figure 2. Representative scanning electron micrographs of dentin surfaces treated with sandblasting, silica coating, hydrofluoric acid etching, or the self-etching ceramic primer either alone (contamination before application of the adhesive in self-etch mode) or before/after phosphoric acid etching (contamination before application in etch-and-rinse mode). Note that contamination with the universal primer is not shown as it was not visible. Original magnification $\times 5000$. (a): Phosphoric acid (control etch-andrinse, group 1). (b): Phosphoric acid $\rightarrow$ sandblasting (group 3). (c): Phosphoric acid $\rightarrow$ silica coating (group 5). (d): Phosphoric acid $\rightarrow$ hydrofluoric acid (group 7). (e): Phosphoric acid $\rightarrow$ self-etching ceramic primer (group 9). (f): Sandblasting $\rightarrow$ phosphoric acid (group 10). (g): Silica coating $\rightarrow$ phosphoric acid (group 12). (h): $\mathrm{Hy}$ drofluoric acid $\rightarrow$ phosphoric acid (group 14). (i): Self-etching ceramic primer $\rightarrow$ phosphoric acid (group 16). (j): Sandblasting (group 19). (k): Silica coating (group 21). (I): Hydrofluoric acid (group 23). (m): Self-etching ceramic primer (group 25). Abrasive remnants are marked by $\uparrow$.

contamination with the self-etching ceramic primer (Figure 1e,i,m). Depending on the sequence of phosphoric acid etching, the surface precipitates either covered the enamel etching pattern (Figure 1e) or could not be removed by phosphoric acid etching (Figure 1i).

When etched dentin (Figure 2a) was contaminated by sandblasting (Figure $2 \mathrm{~b}$ ) or silica coating (Figure 2c), the surface was damaged and cracked, the exposed collagen network was removed, and dentinal tubules were no longer visible. When phosphoric acid etching was performed after sandblasting (Figure 2f) or silica coating (Figure $2 \mathrm{~g}$ ), the surface became partly etched and some tubules were visible. If sandblasting or silica coating was not followed by phosphoric acid etching (ie, if the universal adhesive was applied in SE), the dentin surface was damaged (Figure 2j,k). Hydrofluoric acid contamination of etched dentin resulted in an amorphous surface precipitation (Figure $2 \mathrm{~d}, \mathrm{~h}, \mathrm{l}$ ) that also partly covered the dentinal tubules. Slight surface precipitation was also visible after contamination with the selfetching ceramic primer (Figure 2e,i,m).

\section{DISCUSSION}

This study aimed to simulate potential contamination of dental hard tissues with different repair conditioning measures. Due to the large number of specimens, bovine specimens rather than human teeth were used. A recent systematic review found 
that bovine teeth can be a suitable alternative for human enamel and dentin substrates in shear bond strength tests as no significant differences have been detected in shear bond strength between human and bovine enamel and dentin. ${ }^{12}$ Adhesion was tested using a universal adhesive containing 10-MDP, but without a silane component. A universal adhesive was chosen not only as it can be applied using different etching strategies (selective enamel etch, $\mathrm{ER}$, and SE) but also as universal adhesives can be used for conditioning of restorative materials when restorations need to be repaired. The functional monomer 10-MDP can bond to zirconia and nonprecious metals by ionic and hydrogen interactions of the phosphate group with the oxide layer of the material ${ }^{13}$ while silane-containing adhesives bond to silica-based materials or silica fillers by forming siloxane linkages. ${ }^{14}$ Nevertheless, for repair conditioning of glass ceramics, a separate pretreatment step with a silane-containing solution or a universal primer is recommended to reduce the possibility of hydrolytic degradation of the ceramic-resin bonding. ${ }^{15,16}$ As opposed to the universal adhesive, the universal primer includes not only phosphoric acid methacrylate but also silane methacrylate (capable of bonding to silicate surfaces) and disulfide methacrylate (capable of bonding to precious metals).

Besides the universal primer, the contamination effects of different repair measures to increase surface roughness of a restorative material by physical (sandblasting, silica coating) or chemical (hydrofluoric acid etching, self-etching ceramic primer) measures were tested. An increased surface roughness might allow for better wettability by the adhesive. In addition to surface roughening, silica coating might further improve repair bond strength due to the incorporation of silica particles. Thereby, formation of Si-O-Si-bonds to silane-containing adhesives or universal primers becomes possible. ${ }^{17}$

For all simulated repair surface conditioning measures, the duration of contamination was based on the duration of application recommended for conventional use of the respective products. Under clinical conditions, contact time to dental hard tissues might be shorter, when unintended contamination is noticed and stopped.

For the ER, air abrasion and silica coating reduced enamel and dentin bond strength and increased the amount of adhesive failures when contamination was performed on etched surfaces. This observation is in line with previous studies showing reduced bond strength of etched enamel and dentin after silica coating. ${ }^{18,19}$ The SEM images indicate that the enamel etching pattern and the exposed collagen network of dentin was removed by sandblasting. Conversely, when phosphoric acid etching was performed after sandblasting contamination, bond strength values were not reduced and enamel and dentin specimens presented an etched surface. Previous studies indicated that sandblasting of dental hard tissues does not affect bond strength or margin quality adversely if sandblasted surfaces are cleaned with phosphoric acid ${ }^{10,11}$ or water spray before adhesive application. ${ }^{20}$ For the SE, sandblasting contamination impaired bond strength values and increased the amount of adhesive failures, probably as the surface was not washed/cleaned, and loose abrasion particles were only air blown.

Hydrofluoric acid contamination of enamel resulted in significantly lower bond strength values, independently of the application sequence and the adhesive strategy. Saracoglu and others ${ }^{4}$ demonstrated that $5 \%$ and $9.5 \%$ hydrofluoric acid inhibited enamel bond strength independently whether applied before or after phosphoric acid etching. However, in contrast to the present study, the etch-andrinse adhesive performed slightly better if hydrofluoric acid was applied after phosphoric acid etching instead of before. ${ }^{4}$ Interestingly, in the present study, enamel specimens presented clearly different surface characteristics (Figure 1d,h). While the sequence phosphoric acid etching/hydrofluoric acid contamination resulted in an etching pattern with only a few visible surface precipitates, the reverse order led to an amorphous surface without any signs of etching. Hydrofluoric acid is known to form dense amorphous fluoride precipitates on the tooth surface, which most probably cannot be removed by further phosphoric acid etching. However, irrespective of the sequence of phosphoric acid etching, hydrofluoric acid contamination significantly reduced enamel bond strength.

Shear bond strength measurement on hydrofluoric acid-exposed dentin yielded ambiguous results. Previous studies found that contact to hydrofluoric acid significantly impaired dentin bond strength, independent of the etching sequence. ${ }^{4,5}$ Nevertheless, ultramorphologic analyses showed distinct differences between the etching sequences: If dentin was first etched with phosphoric acid, a collagen-rich layer was exposed, which probably collapsed when further etched with hydrofluoric acid. As a result, a thinner hybrid layer was formed and mineral precipitates were detected at the bottom of the hybrid layer. If hydrofluoric acid etching was performed first, calcium fluoride precipitates were 
formed that hampered phosphoric acid etching. Underneath the precipitates, a collagen-rich layer was formed, which could not be infiltrated by resin. ${ }^{5}$ In the present study, hydrofluoric acid contamination led to precipitates that were covering the surface (Figure 2d) or partial occlusion of dentinal tubules (Figure 21). Phosphoric acid etching of hydrofluoric acid contaminated dentin was unable to remove the surface precipitates (Figure $2 \mathrm{~h}$ ). Nevertheless, bond strength was significantly impaired only when the adhesive was applied in SE or when phosphoric acid etched dentin was contaminated (group 7). It remains unclear why the sequence hydrofluoric acid contamination/phosphoric acid etching led to only slightly reduced bond strength values, even after thermocycling. Similar results were obtained with the self-etching ceramic primer. On both enamel and dentin, the primer led to surface precipitates (Figure 1e,i,m, Figure 2e,i,m) that impaired bond strength significantly if the universal adhesive was applied in SE (Figures $1 \mathrm{~m}$ and $2 \mathrm{~m}$ ). Etched enamel became visible underneath the precipitates (Figure 1i). Dentinal tubules were partly occluded by the precipitation (Figure $2 \mathrm{e}, \mathrm{i}, \mathrm{m}$ ), but the precipitation seemed to be less severe than after hydrofluoric acid contamination. Further studies have to be performed to fully elucidate how the self-etching ceramic primer affects enamel and dentin adhesion.

The universal primer did not affect bond strength adversely. Previous studies showed that the contamination of enamel ${ }^{19}$ or dentin ${ }^{21}$ with silane solutions did not reduce bond strength of subsequently applied adhesives. Potentially, the universal primer increased the wettability of the contaminated enamel or dentin surface under certain conditions, leading to slightly higher bond strength values.

The brittleness of the materials included in this study makes their failure difficult to predict and their bond strength less reliable. The Weibull statistic takes into account the variable existence of strength-controlling flaws within brittle materials by providing information about the variability of their bond strengths. A high Weibull modulus reflects a narrow variability of bond strengths and consequently a high reliability on the characteristic strength. Materials or methods with a high Weibull modulus are likely to be less technique-sensitive than those with a low Weibull modulus and should therefore be preferred. ${ }^{22}$ Irrespective of the substrate or the adhesive strategy, our results showed the highest Weibull moduli and characteristic strengths in the control groups or when only the universal primer was applied, with the exception of group 8. Thus, contamination of enamel or dentin by repair conditioning measures seemed to result in a less reliable compound between repair restoration and tooth structure and should therefore ideally be avoided.

The present study only assessed the effect of repair surface conditioning measures on enamel and dentin shear bond strengths. However, in a clinical setting mixed surfaces with both tooth and restoration surfaces require optimal repair pretreatment. The potential interference of tooth surface conditioning measures (ie, phosphoric acid etching) on repair bond strength was not assessed in the present study. In particular, zirconia and nonprecious metals should not be treated with phosphoric acid to avoid the formation of a stable phosphate layer inhibiting the adhesion of primers containing phosphoric acid methacrylate (eg, 10-MDP). ${ }^{23}$

Based on these results, the null hypothesis that repair conditioning measures do not affect bond strength of a universal adhesive to enamel or dentin has to be rejected. Within the limitations of this study, the following clinical recommendations for repairing restorations next to enamel and dentin substrates may be suggested: 1) contamination of enamel/dentin by repair conditioning measures should be avoided; 2) if enamel/dentin is contaminated, use of phosphoric acid (ER) before applying a universal adhesive may minimize the effects of the contamination; and 3) contamination of enamel/ dentin with a universal primer alone may not significantly affect the bond strength of dentin or enamel to resin composite when using a universal adhesive.

These recommendations are in line with a recently published policy statement on the repair of restorations published by the FDI World Dental Federation: When tooth substance is next to a restoration in need of repair, physical repair surface conditioning measures should be performed before phosphoric acid etching of the tooth substance. ${ }^{24}$ However, it has also been suggested that repairs be performed in a two-step technique if tooth substance is present: In the first step, only the tooth surface is covered using composite. Afterward, physical/chemical repair surface conditioning measures are applied to both the composite and the adjacent restoration. ${ }^{25}$ Given the results of the present study, this technique seems rational as it combines optimal repair bonding procedures for both tooth surfaces and restorations. 


\section{Note}

This study was previously presented at the 9th CONSEURO, June 14-15, 2019, Berlin, Germany.

\section{Conflict of Interest}

The authors of this manuscript certify that they have no proprietary, financial, or other personal interest of any nature or kind in any product, service, and/or company that is presented in this article.

(Accepted 29 January 2020)

\section{REFERENCES}

1. Kanzow $P$, Wiegand A, Göstemeyer G, \& Schwendicke F (2018) Understanding the management and teaching of dental restoration repair: Systematic review and metaanalysis of surveys Journal of Dentistry 69 1-21, http://dx. doi.org/10.1016/j.jdent.2017.09.010

2. Hickel R, Brüshaver K, \& Ilie N (2013) Repair of restorations - Criteria for decision making and clinical recommendations Dental Materials 29(1) 28-50, http://dx. doi.org/10.1016/j.dental.2012.07.006

3. Kanzow P, Wiegand A, Schwendicke F, \& Göstemeyer G (2019) Same, same, but different? A systematic review of protocols for restoration repair Journal of Dentistry 86 116, http://dx.doi.org/10.1016/j.jdent.2019.05.021

4. Saracoglu A, Özcan M, Kumbuloglu O, \& Turkun M (2011) Adhesion of resin composite to hydrofluoric acidexposed enamel and dentin in repair protocols Operative Dentistry 36(5) 545-553, http://dx.doi.org/10.2341/ 10-312-L

5. Loomans BAC, Mine A, Roeters FJM, Opdam NJM, De Munck J, Huysmans MCDNJM, \& Van Meerbeek B (2010) Hydrofluoric acid on dentin should be avoided Dental Materials 26(7) 643-649, http://dx.doi.org/10.1016/ j.dental.2010.03.007

6. Szep S, Gerhardt T, Gockel H-W, Ruppel M, Metzeltin D, \& Heidemann D (2000) In vitro dentinal surface reaction of $9.5 \%$ buffered hydrofluoric acid in repair of ceramic restorations: A scanning electron microscopic investigation Journal of Prosthetic Dentistry 83(6) 668-674, http:// dx.doi.org/10.1016/S0022-3913(00)70069-2

7. Pioch T, Jakob H, García-Godoy F, Götz H, Dörfer CE, \& Staehle HJ (2003) Surface characteristics of dentin experimentally exposed to hydrofluoric acid European Journal of Oral Sciences 111(4) 359-364, http://dx.doi.org/ 10.1034/j.1600-0722.2003.00048.x

8. Lopes GC, Perdigão J, Baptista D, \& Ballarin A (2019) Does a self-etching ceramic primer improve bonding to lithium disilicate ceramics? Bond strengths and FESEM analyses Operative Dentistry 44(2) 210-218, http://dx.doi. org/10.2341/17-355-L

9. Prado M, Prochnow C, Marchionatti AME, Baldissara P Valandro LF, \& Wandscher VF (2018) Ceramic surface treatment with a single-component primer: Resin adhesion to glass ceramics Journal of Adhesive Dentistry 20(2) 99-105, http://dx.doi.org/10.3290/j.jad.a40303

10. Onisor I, Bouillaguet S, \& Krejci I (2007) Influence of different surface treatments in marginal adaptation in enamel and dentin Journal of Adhesive Dentistry 9(3) 297-303, http://dx.doi.org/10.3290/j.jad.a12388

11. Santos MJMC, Bapoo H, Rizkalla AS, \& Santos GC (2011) Effect of dentin-cleaning techniques on the shear bond strength of self-adhesive resin luting cement to dentin Operative Dentistry 36(5) 512-520, http://dx.doi.org/10. 2341/10-392-L

12. de Carvalho MFF, Leijôto-Lannes ACN, Rodrigues MCN, Nogueira LC, Ferraz NKL, Moreira AN, Yamauti M, Zina LG, \& Magalhães CS (2018) Viability of bovine teeth as a substrate in bond strength tests: A systematic review and meta-analysis Journal of Adhesive Dentistry 20(6) 471-479, http://dx.doi.org/10.3290/j.jad.a41636

13. Nagaoka N, Yoshihara K, Feitosa VP, Tamada Y, Irie M, Yoshida Y, Van Meerbeek B, \& Hayakawa S (2017) Chemical interaction mechanism of 10-MDP with zirconia Scientific Reports 7 45563, http://dx.doi.org/10.1038/ srep45563

14. Matinlinna JP, Lung CYK, \& Tsoi JKH (2018) Silane adhesion mechanism in dental applications and surface treatments: A review Dental Materials 34(1) 13-28, http:// dx.doi.org/10.1016/j.dental.2017.09.002

15. Yao C, Yang H, Yu J, Zhang L, Zhu Y, \& Huang C (2018) High bond durability of universal adhesives on glass ceramics facilitated by silane pretreatment Operative Dentistry 43(6) 602-612, http://dx.doi.org/10.2341/ 17-227-L

16. Elsayed A, Younes F, Lehmann F, \& Kern M (2017) Tensile bond strength of so-called universal primers and universal multimode adhesives to zirconia and lithium disilicate ceramics Journal of Adhesive Dentistry 19(3) 221-228, http://dx.doi.org/10.3290/j.jad.a38436

17. Rodrigues SA Jr., Ferracane JL, \& Della Bona A (2009) Influence of surface treatments on the bond strength of repaired resin composite restorative materials Dental Materials 25(4) 442-451, http://dx.doi.org/10.1016/j. dental.2008.09.009

18. Özcan M, Schoonbeek G, Gökçe B, Çömlekoglu E, \& Dündar M (2010) Bond strength comparison of amalgam repair protocols using resin composite in situations with and without dentin exposure Operative Dentistry 35(6) 655-662, http://dx.doi.org/10.2341/10-091-L

19. Hannig C, Hahn P, Thiele PP, \& Attin T (2003) Influence of different repair procedures on bond strength of adhesive filling materials to etched enamel in vitro Operative Dentistry 28(6) 800-807.

20. Sutil BGDS \& Susin AH (2017) Dentin pretreatment and adhesive temperature as affecting factors on bond strength of a universal adhesive system Journal of Applied Oral Sciences 25(5) 533-540, http://dx.doi.org/ 10.1590/1678-7757-2016-0500

21. Chen L, Hammond BD, Alex G, \& Suh BI (2017) Effect of silane contamination on dentin bond strength Journal of Prosthetic Dentistry 117(3) 438-443, http://dx.doi.org/10. 1016/j.prosdent.2016.06.021

22. Scherrer SS, Cesar PF, \& Swain MV (2010) Direct comparison of the bond strength results of the different test methods: A critical literature review Dental Materi- 
Operative Dentistry

als 26(2) e78-e93, http://dx.doi.org/10.1016/j.dental.2009. 12.002

23. Han IH, Kang DW, Chung CH, Choe HC, \& Son MK (2013) Effect of various intraoral repair systems on the shear bond strength of composite resin to zirconia Journal of Advanced Prosthodontics 5(3) 248-255, http://dx.doi.org/10.4047/jap.2013.5.3.248
24. FDI World Dental Federation (2020) Repair of restorations: adopted by the General Assembly: September 2019, San Francisco, United States of America International Dental Journal 70(1) 7-8, http://dx.doi.org/10.1111/idj. 12552

25. Haller B (2019) Defekte Restaurationen: reparieren statt flicken Der Freie Zahnarzt 63(11) 68-79, http://dx.doi.org/ 10.1007/s12614-019-7990-1 


\section{Danksagung}

Ich bedanke mich ganz herzlich bei Frau Prof. Dr. Annette Wiegand für die freundliche und stetige Unterstützung sowie ihre konstruktiven Anregungen seit Beginn meiner Tätigkeit in der Göttinger Poliklinik für Präventive Zahnmedizin, Parodontologie und Kariologie. Sie stand mir für Fragen jederzeit zur Verfügung und begleitete mich kontinuierlich und zielführend während meines Habilitationsprozesses.

Außerdem bedanke ich mich bei meinen beiden Doktorvätern: Herr Prof. Dr. Dr. Michael Oellerich begeisterte mich bereits während meines Studiums für die Forschung. Herr Prof. Dr. Falk Schwendicke trug mit seinen konstruktiven Ideen und seiner methodischen Unterstützung ebenfalls aktiv zu dieser Arbeit bei.

Ebenfalls möchte ich mich bei allen Mitarbeiter*innen, Doktorand*innen und Kolleg*innen bedanken, die mich auf meinem Weg zur Habilitation unterstützten. Mein besonderer Dank gilt dabei auch den Mitarbeiter*innen im Labor.

Des Weitern gilt mein Dank meiner Partnerin Friederike Büttcher und den Familien, die mich auf meinem Weg begleiteten und immer für mich da waren. Ich bedanke mich hiermit für ihre stetige Unterstützung und ihr Verständnis.

Nicht zuletzt bedanke ich mich auch bei den Kolleg*innen anderer Universitäten sowie den Zahnärzt*innen, die an meinen Umfragestudien teilnahmen. 